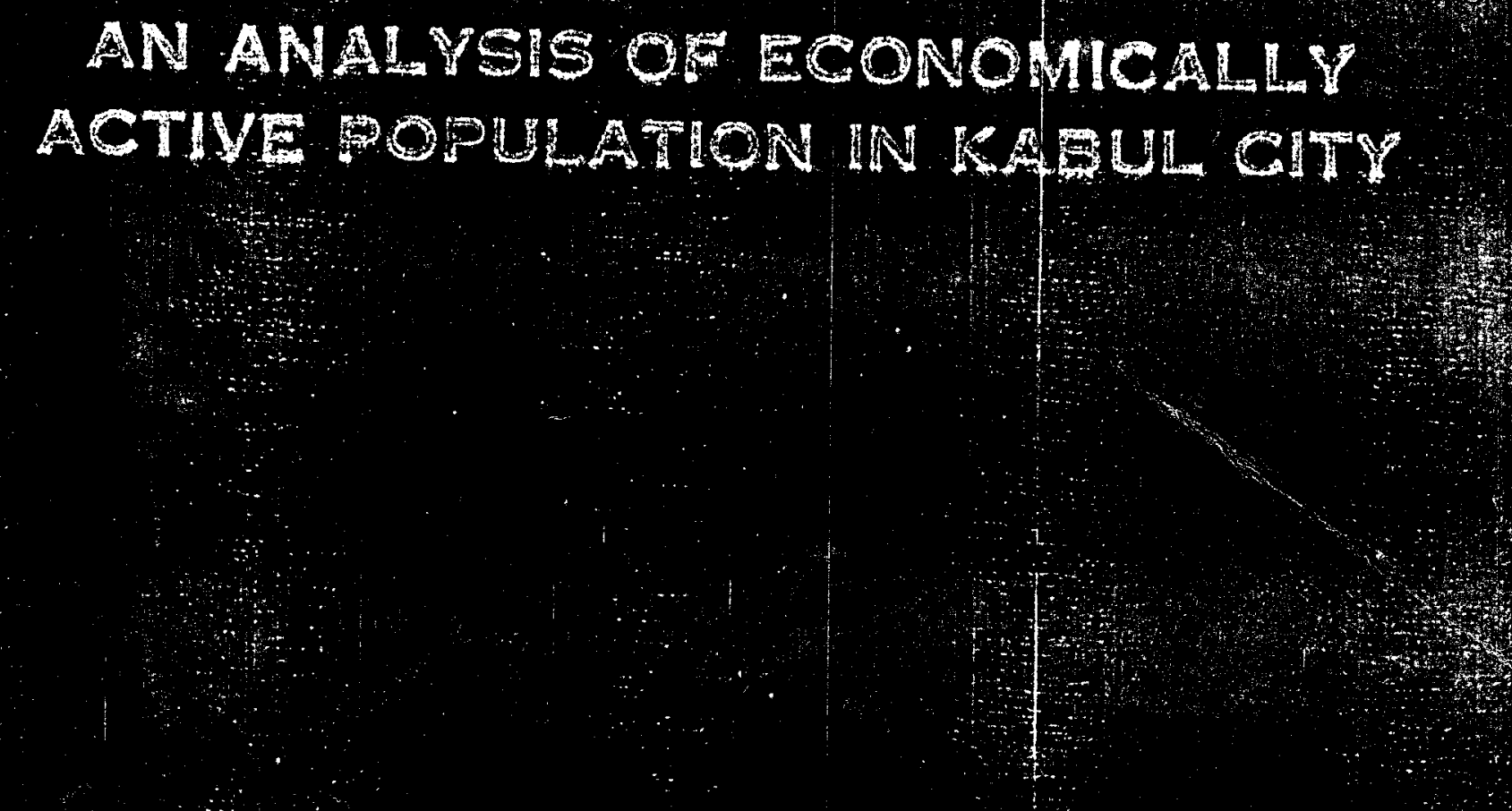

\title{
siv
}

GHULAR FROUO KAMN

A DisecrTation

8URMITTED AS THE FULFLUERT FOR THE

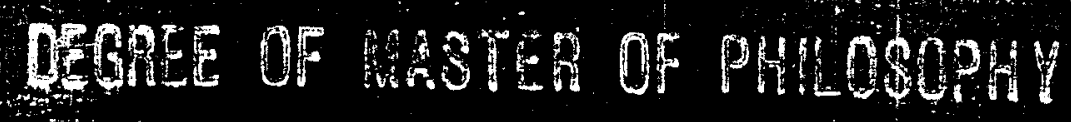

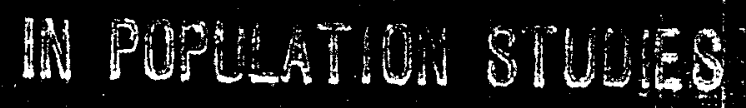

IMTERMATIOMAL WBOUTUTE FOR POPULATION SBENGES

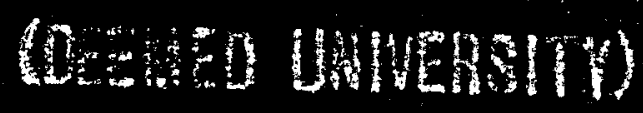

DECHAM, BOMGAY 1201 


\section{An Analysis of Economically Active Population in Kabul City}

by

\section{GHULAM FAROUQ KAMIN}

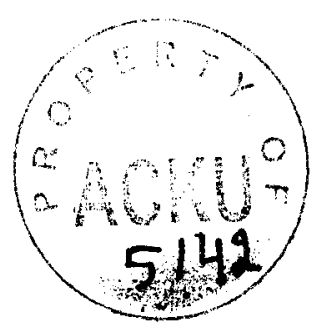

A DISSERTATION

SUBMITTED AS THE FULFILMENT FOR THE DEGREE OF

MASTER OF PHILOSOPHY

IN

POPULATION STUDIES

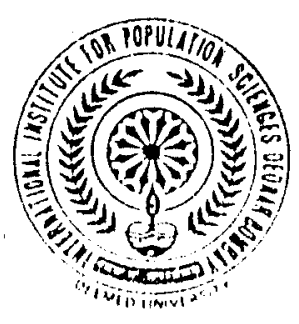

INTERNATIONAL INSTITUTE FOR POPULATION SCIENCES

( DEEMED UNIVERSITY)

DEONAR, BOMBAY

1991 


\section{जनसंख्या विज्ञान}

\section{का \\ अन्तराष्ट्रीय संस्थान}

( घिइषविचालय समतुष्य)

DR. K. SAINIVASAN

DIAECTOR

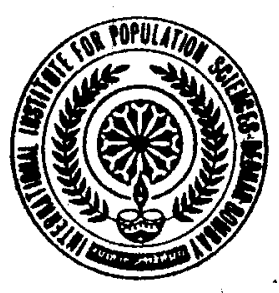

COVANOI STATION ROAO.

DEONAR, gOMEAT-40008B. inOIA international institurte Pox polpulation Bollances

(DEEMEO UNIVERSITY)

Tolegrams IDEMOGRAPHY. CHEMBUR, BOMBAY Telephones: D I AE C T O:5662062 OFFICE, 6611347

\section{CERTIFICATE}

This is to certify that Mr. Ghulam Farouq Kamin has prepared this dissertation entitled "An Analysis of Economically Active Population in Kabul City" in fulfilment of the requirements for the award of the Degree of Master of Philosophy in Population Studies of this Institute, under my supervision and guidance. To the best of my knowledge, this work is original and has not been submitted either to this Institute or elsewhere for the award of any Degree or Certificate/Diploma.

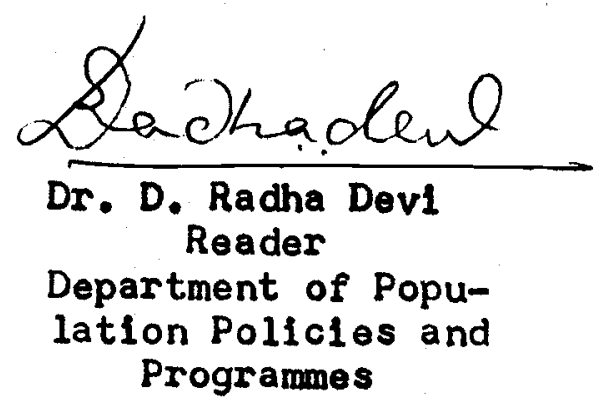




\section{ACKNOUILEDGEMENTS}

With great pleasure I acknowledge my heartfelt thanks and sincere gratitude to Dr. D. Radha Dev1, Reader, Department of Fopulation Policies and Programmes, International Institute for Population Sciences, Bombay, for her excellent guidance, unstinted support, constant encouragement, helpful discussions and valuable suggestions throughout the preparation of this dissertation. She has always been available to show the right direction at all stages of the writing of this work. Without hei constant guidance and intellectual comments this dissertation would not have been completed in time.

I am grateful to Dr. K. Srinivasan, Professor and Director of the Institute, whose valuable suggestions and constructive comments at the time of presentation of the proposal of the dissertation topic have made important improvenent in my perspactive.

In the course of this work I have benefited from my consultation with several members of the faculty, anong them are krof. S. Mukerj1, Prof. K.B. Pathak, Prof. Shekhar Mukherji, Dr. F. Ram and Mr. K.B. Gotpagar. I am very grateful to them a 11.

I would like to thank Mr. R.T. Randeria, Librarian, M. K.V.R. Rao, Dy. Librarian and all the Library staff for helping me in searching the necessary literature and materials. 
It is with pleasure that I acknowledge the contribution of Mr. Gopal Padmashall, the Institute's Artist and the skill with which Mir. S. Ghosh typed the manuscript.

\section{Ghulam Farouq Kamin}

International Institute for Population Sclences, Deonar, Bombay-400 088. April, 1991. 
TABLE OF CONTENTS

Page

ACKNONLELGEMENTS

TABLE OF COINTENTS

LIST OF MBBLES

LIST OF FIGUKES

CHAPTER I - INTRODUCTION $1-10$

1.1. BACKGROUND OF THE STUDY 1

1.2. OBJECTIVES

1.3. THE STUDY AREA

1.4. ORGAINISATION OF THE STUOY

CHAPTER II - DATA, METHODOLOGY AND REVIEW OF LITERATURE

2.1. INTRONUCTION

2.2. DATA SOURCES AND LIMITATIONS

2.3. METHODOLOGY

2.4. REVIEW OF LITERATURE

CHAPTER III - PROFILE OF KABUL CITY

3.1. INTRCDUCTION

3.2. SIZE, DISTRIBUTION AID GRONTH OF THE POPULATION

3.3. NATIONALITY AND MOTHER TONGUE 28

3.4. SEX-AGE STRUCTURE OF THE POPULATION 31

3.4.1. Sex Structure 31

3.4.2. Age Structure 34

3.5. MARITAL STATUS 37

3.6. HOUSEHOID COMPOSITION 40

3.7. LITERACY AND EDUCATIONAL ATTAINMENT 44

3.7.1. Literacy 44

3.7.2. School Enrolment $\quad 47$

3.7.3. Educational Attainnent 48 
3.8. FERTILITY, MORTALITY AND MIGRATION 50

3.8.1. Fertility 50

3.8.2. Mortality 52

3.8.3. Migration 53

a. Households by Number of Migrants 55

b. Age Structure of Migrants 55

(1) Age and Sex Composition of Migrants and Non-migrants $\quad 57$

(ii) Duration of Residence of the Migrants in Kabul City 60

c. Sex Composition of Migrants 61

d. Educational Attainment of Migrants and Non-migrants $\quad 63$

3.9. SUMMARY

CHAFTER IV - LEVEL OF LABOUR FORCE PARTICIPATION AID 6 66-86 OTHER RELATED FINDINGS

4.1. INTRODUCTION 66

4.2. ACTIVITY RATES 66

4.3. AGE-SEX SPECIFIC ACTIVITY RATES 68

4.4. MARITAL STATUS SPECIF IC FEMALE ACTIVITY RATES BY AGE $\quad 70$

4.5. EDUCATION SPECIFIC ACTIVITY. RATES 73

4.6. ECONOMIC DEPENDENCY RATIO 74

4.7. GROSS YEARS OF ACTIVE LIFE 75

4.8. WORKING LIFE TABLE 77

4.8.1. Length of Working Life 78

4.8.2. Loss of Active Years by Mortality 82

4.8.3. Loss of Active Years by Retirement 8 ?

4.8.4. Labour Force Accession (Entry) 83

4.8.5. Replacement Rate and Replacement Ratio 84

4.9. SUMMARY 84

CHAPTER $V$ - COMPOSITION OF ECONOMICALLY ACTIVE POPULATION 87-110

5.1. INTRCDUCTION 87

5.2. AGE-SEX COMPOSITION 87

5.3. EDUCATIONAL COMPOSITION 90 
Page

5.4. MARITAL STATUS COMPOSITION 93

5.5. INDUSTRIAL COMPOSITION 96

5.6. OCUPATIONAL COMPOSITION 100

5.7. SEX-LABELLING OF OCCUPATIONAL
CATEGORIES

5.8. MIGRANTS AND THEIR WORK 104

5.9. SUMMARY 109

CHAPTER VI - UNDERUTILIZATION OF LABOUR

111-123

6.1. INTRODUCTION

111

6.2. UNEMPLOYMENT 112

6.3. UNDEREMPLOYMENT 120

6.4. SUMMARY 122

CHAPTER VII - SUMRARY AND CONCLUSIONS

124-139

7.1. SUMAARY

124

7.2. CONCLUSIOIS AND RECOMENDATIONS

REPERENCES

$140-143$

APPENDICES

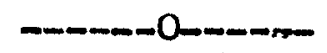


1.1 Percentage Share of Kabul Province and Kabul City In Afghanistan's Selected Characteristics, 1986

3.1 Percentage Distribution and the Growth Rate of the Population of Kabul City by Districts in 1979 and 1986

3.2 Percentage Distribution of Population by Nationality and Sex, Kabul City, 1986

3.3 Percentage Distribution of the Population by Districts and Nationality, Kabul City, 1986

3.4 Percentage Distribution of the Population by Mother Tongue, Kabul City, 1986

3.5 Sex Ratio of the Population of Kabul City by Broad Age Group in 1965 and 1986

3.6 Sex Ratio of the Population of Kabul City by Districts in 1979 and 1986

3.7 Sex Ratio of the Population by Broad Age Group and Districts, Kabul City, 1986

3.8 Percentage Distribution of the Population of Kabul City by Broad Age Group and Sex in 1965 and 1986

3.9 Percentage Distribution of tre Population Aged 10 years and above by Marital Status and Sex, Kabul City, 1986

3.10 Percentage Distribution of Population Aged 10 years and above by age, Sex and Marital Status, Kabul City, 1986 and Tehran City, 1976

3.11 Percentage Distribution of the Households by the Size of Household, Kabul City, 1986

3.12 Percentage Distribution of Housoholds and the Average Size of Household by District, Kabul City, 1986

3.13 Percentage Distribution of Households by the Size of Household in each District in Kabul City, 1986

3.14 Percentage Distribution of Households by the Number of Rooms Avallable in each District in Kabul City, 1986

3.15 Percentage Distribution of Population Aged 10 years and above by Nationality, Litoracy and Sex, Kabul City, 1986 
Table No.

Page

3.16 Effective Literacy Rates by Districts, Kabul City, 1986

3.17 Percentage Distribution of the Sex-wise Population Enrolled in School by Grade, Kabul City, 1986

3.18 Percentage Distribution of the Literate Population Aged 10 years and above by Completed

Level of Education, Kabul City, 1986

3.19 Fertility Indices by Districts, Kabul City, 1986

3.20 Fercentage Distribution of Households by Number of Migrants and Size of Household, Kabul City, 1986

3.21 Percentage Distribution of Life-time Migrants and Non-migrants by Age and Sex, Kabul City, 1986

3.22 Median Age of Migrants by Duration of Residence and Sex, Kabul City, 1986

3.23 Sex Ratios of Migrants and Non-nigrants by Broad Age Groups, Kabul City 1986, Tehran City, 1976

3.24 The Sex Ratio and the Percentage Distribution of Migrants by Province of Birth, Kabul City, 1986

3.25 Sex-ratios of Migrants by Age and by Duration of Residence, Kabul City, 1986

3.26 Percentage Distribution of Migrants and Nonmigrants who are Aged 10 years or more by Educational Levels and Sex, Kabul City, 1986

4.1 Economic Activity Rates by Districts, Kabul City, 1986

4.2 Sex-age Specific Activity Rates, Kabul City 1986, Tehran City - 1976.

4.3 Marital Status Specific Aotivity Rates by Age, Female Population, Kabul City, 1986

4.4 Education Specific Activity Rates, Kabul City, 1986

4.5 Economic Dependency Ratio by Sex and Districts, Kabul City, 1986

4.6 Gross years of Active Life for Males in Aged 10 years and over and 10 to 65 years, Kabul City, 1986

4.7 Working Life Table for Males in Kabul City, 1986

5.1 Sex-ratio of Economically Active Population by Districts, Kabul City, 1986

5.2 Percentago Distribution of Economically Active Population by Levels of Educational Attalnment, Industry and Sex, Kabul City 
5.3 Percentage of Economically Active Fernale Population by Marital Status and Occupation, Kabul City, 1986

5.4 Percentuge Distribution of Economically Active Population by Industry and District, Kabul City, 1986

5.5 Percentage Distribution of Economically Active Population by Occupation and DIstricts, Kabul City, 1986

5.6 Index of Female Economic Activity in Broad Occupational Categories

5.7 Index of Fernale Economic Activity in Occupational Groups, Kabul City, 1986

5.8 Level of Education of Migrants by Place of Last Work, Kabul City, 1986

5.9 Percentage Distribution of Migrants and Nonmigrants by Sex and Occupational Divisions, Kabul City, 1986

5.10 Helative Difference in Occupational Divisions for Migrants and Non-migrants, Kabul City, 1986

5.11 Share of Migrants Horkers Among Total Workers in each Occupational Group, Kabul City, 1986

6.1 Age-specific Unemployment Rates for Kabul and Tehran

6.2 Percentage Distribution of Persons Seeking Job for the first time by Age Group, Kabul City, 1986

6.3 Percentage Distribution of Unemployed Persons by Age and Sex

6.4 Percentage D1 stribution of Unemployed Persons by Type of Unemployment, and Sex

6.5 Female Unemployment Rates by Age and llarital Status, Kabul City, 1986

óó Percentage Distribution of Unemployed Fernales by Age and Marital Status, Kabul City, 1986

6.7 Percentage Distribution of Unemployed Females by Type of Unemployment and Marital Status, Kabul City, 1986

6.8 District-wise Unemployment Rates, Kabul City, 1986

0.9 Hercentage Distribution of Highly Educated Persons by Sector of Economic Activities 


\section{LIST OF FIGURES}

Figure No.

3.1 Sex-age Pyramid of Population, Kabul City, 1986

3.2 Sex-age Pyramid of Population, Tehran City, 1976

3.3 Percentage Migrants of Kabul City by Selective Provinces of Birth, 1986

3.4 Age Pyramlds of Migrants and Non-migrants in Kabul City, 1986

4.1 Age-sex Specific Activity Rates, Kabul City, 1986; Tehran City, 1976

4.2 Marital Status Speciflo Female Activity Rates by Age, Kabul City, 1986

4.3 Survivors of 100,000 Males Born Allve, Kabul City, 1986

5.1 Age-sex Pyramid of Economically Active Population, Kabul City, 1986

5.2 Distribution of Male and Female Workers by Completed Level of Education, Kabul City, 1986

5.3 Marital Status Composition of Economically Active Female Population, Kabul City, 1986 
1.1. BACKGROUND OF THE STUDY

With the continuous change that is taking place in the structure of every economy in this modern exa the role of labour is assuming more and more importance. The shift from agriculture to industry and from industry to service which is part of the process of development and modernization has given the utilization of manpower the central place (Levitan et.al, 1972). Thus in both labour surplus and labour scarce economies planned utilization of labour became an absolute necessity as they are the chief contributors to prosperity and growth.

In this context it is very important to know the allocation of workers among different industries and occupations, and the changes that are taking place in the industrial and occupational structure. Further, productivity of labour will depend upon the skills and abilities of the labour force which in turn depends upon factors like health, education, work experience etc.

In less developed countries. changes in the structure of the economy and changes in the composition of labour will be more pronounced in the urban areas. The larger the slze of the urban centre greater will be the complexity of labour.

This study is concerned with an analysis of the economically active population in Kabul city. Ideally, a detalled study of the changes and composition of economically active population would have 
helped the planners to identify the areas in which more attention should be given to improve the production and welfare of the people. But as is well known, Afghanistan has only very limited data to help achieve this objective. Hence, besides the attempt to make full utilization of the available data, an attempt will also be made to highlight the gaps in the existing information which need to be filled, ano the results analysed, if any meaningful planning is to be done for the development of this country. In this context it should be pointed out thit the Afghanistan Government has been involved in National Planing for development since 1956 with financial aid from USSR and USA (UNFPA 1978). But even in 1986, 30 years after the initiation of development planning, Afghanistan was grouped with the least developed countries by World Bank, falling within the group of countries with a per capita income of $\$ 200$ or less (World Bank, 1988).

It's demographic characteristics, for which data are available, are also matching with that of a really backward economy (see Appendix 1). It had a very yound population with 45 percent of children falling in the less than 15 years age group in 1979. Similarly its life expectancy at birth was 41 years. But urban life expectancy vas slightly better, 49-50 years. Its crude birth rate of 48 , crude death rate of 29 , total fertility rate of 7 and infant mortality rate of 182 are among the highest in the world. The population is mainly rural in character with only 15 percent living in urban areas. Thefe are information from the 1979 census of Afghanistan - the first, and $\$ 0$ fal the only census in the country.

This shows clearly that Afghanistan has a fast growing population even if the data are to be accepted with great reservations. 
objectives are as follows:

(1) To outline the demographic and social characteristics of the population, mainly the size, distribution and growth and its composition by age, sex, marital status, educational attainment and household.

(2) To examine the character-specific activity rate of the population, namely, activity rate speciflc for age, sex, education and marital status.

(3) With the help of a working life table attempt will also be made to estimate the expectation of active life, replacement of the labour force by entries, and depletion by deaths and retirements.

(4) The fourth objective is to examine the composition of conomically active population, and to examine differences in occupation by gender and migration status.

(5) Since unutilized labour has a productive potential which can be used to improve the economy, the fifth, objective of this study is to expose the situation of the underutilization of labour in Kabul city. The study would have been more useful had there been sufficient data to effect a trend analysis. Some data are available from 1965 Greater Kabul Census and it will be used for studying the changes, if any. Besides, a comparison will also be made with another city situation, and for that Tehran city was selected. Tehran is the capital of Iran, the western neighbour of Afghanistan. The two major considerations that led to the selection of Tehran are: the residents of both the cities are Muslims, and as such they 
have socio-cultural similarities, and secondly comparable data are available and accessible for Tehran.

1.3. THE STUDY AREA

This study is restricted to Kabul city alone and the main considerations for deciding on this city are the following: the primary consideration is that Kabul city had a comparatively recent census (1986) the results of which are available for analysis. Moreover, Kabul is the capital of Afghanistan harbouring more than 50 percent of 1 ts 2.01 million urban population which is spread over 93 urban centres (Central statistics office, 1988). It is called a mini-Afghanistan as people from all parts of the country migrate over to this city for one reason or the other. Kabul city is the one and the only primate city ${ }^{1}$ in Afghanistan and compared to other urban centres and rural areas it is possible that it may be concerned with the integration of interrelationship between specialized activities which calls for increasing concentration of population in non-agriculture pursuts (Hawley, 1950). Th1s adds to the importance of the city and neccessitates planning for proper utilization of manpower and avold wastage.

Kabul city situated on the banks of Kabul river is surrounded by mountains and even part of the city is mountainous. This city has special place in Afghanistan economic and demographic map. The per

1. Primate city is a metropolitan area that is enormously larger than the next largest city in which a large percent of urban population is concentrated. See Dennis A. Rondinelli, Secondary Cities in Developing Countries, Sage Publications, California, 1983. 
capita income of Kabul city was 16,704 Afghanies in 1987 (Central Statistics office, 1988), which/more than double the per capita income of the country, 7727 Afghanies (Central statistics office, 1989) in the same year. It is the main centre of education health, communication and transport and services as can be seen from table 1.1 below.

Table 1.1 : Percentage Share of Kabul Province and Kabul City in Afghanistan's Selected Characteristics, 1986.

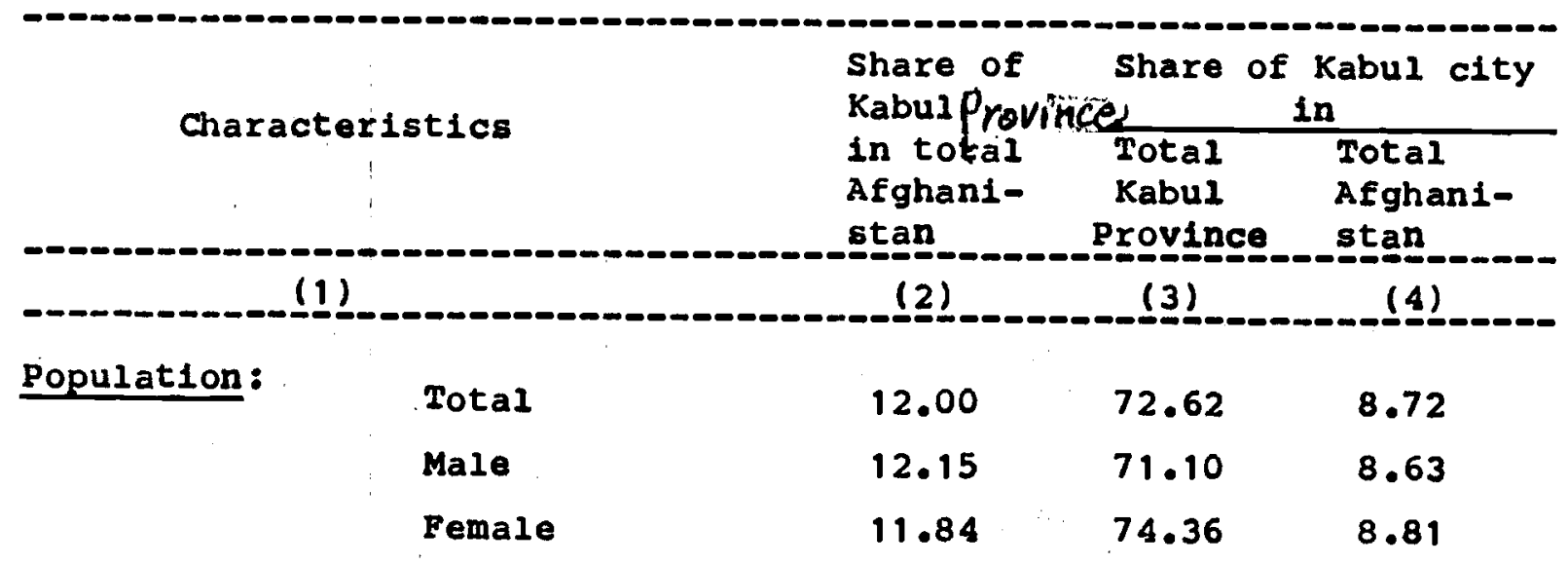

Education :

$\begin{array}{llll}\text { Literacy Cources } & 30.3 & 76.84 & 23.3 \\ \text { Students in Literacy Cources } & 37.8 & 82.19 & 31.1 \\ \text { Graduates from Literacy } & & & \\ \text { Cources } & 77.8 & 97.21 & 75.6\end{array}$

Schools:

Boys School:

\begin{tabular}{|c|c|c|c|c|}
\hline & Total & 18.41 & 60.23 & 11.09 \\
\hline & Primary & 17.80 & 59.50 & 10.59 \\
\hline & Secondary & 20.08 & 62.00 & 12.45 \\
\hline Girls & School: & & & \\
\hline & Total & 32.66 & $71 \cdot 13$ & 23.23 \\
\hline & Primary & 36.89 & 71.05 & 26.21 \\
\hline & Secondary & 23.08 & 71.43 & 16.48 \\
\hline
\end{tabular}


Table 1.1 Contd.

(1)

(2)

(3)

(4)

students:

Male students:

Total
primary

$\begin{array}{lll}44.87 & 85.44 & 38.33\end{array}$

Secondary

$46.00 \quad 85.70 \quad 39.42$

$\begin{array}{lll}35.01 & 85.45 & 28.86\end{array}$

Female students:

Total

$60.97 \quad 94.22 \quad 57.41$

Primary

$\begin{array}{lll}59.18 & 93.85 & 55.54\end{array}$

secondary

$\begin{array}{lll}70.38 & 95.87 \quad 67.47\end{array}$

Teachers:

Male Teachers:

Total

Primary

secondary

Female Teachers:

Total

Primary

Secondary

$\begin{array}{lll}30.14 & 76.36 & 23.02 \\ 28.73 & 66.65 & 19.15 \\ 32.86 & 92.69 & 30.46 \\ & & \\ 73.57 & 96.22 & 70.79 \\ 77.26 & 96.13 & 74.27 \\ 55.86 & 96.87 & 54.11\end{array}$

Government Workers:

Total
Male
Eemale

$\begin{array}{lll}60.0 & - & - \\ 55.43 & - & - \\ 80.0 & - & -\end{array}$

Health:

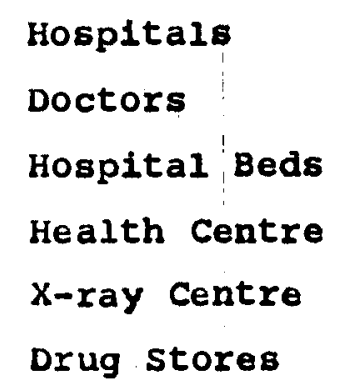

$\begin{array}{lll}22.22 & - & - \\ 62.41 & - & - \\ 54.1 & - & - \\ 13.3 & - & - \\ 46.3 & - & - \\ 34.66 & - & -\end{array}$

Communicat1on:

post offices

$\begin{array}{lll}11.7 & - & - \\ 69.00 & - & - \\ 46.6 & - & -\end{array}$


Table 1.1 Contd.

(1)

(3)

(4)

Transport:

$\begin{array}{llll}\text { Government Vehicals } & 82.53 & - & \text { - } \\ \text { Private Vehicals } & 70.50 & - & \text { - }\end{array}$

Note: - No data

Source: Statistical Year Book 1365 (March 1986 - March 1987) of

Afghanistan, Central statistics office, Kabul, 1987.

Note that some of the information are available only for Kabul province and not for the city, but as the latter has nearly threefourths of the former's population, and in some cases more than that of the facilities it will be a safe assumption, that the city has a majore share of all that is available in Kabul province.

The table 1.1 speaks for itself and shows clearly the importance of Kabul city in the country's social and economic structure. Kabul city is divided into eleven parts called district (Nahia) administered by municipality and each component district has its own importance: The old city of Kabul and the biggest road of Jade-Maiwand are located in first distrlct. second district is the least populated area. The republican palace, big houses with large gardens and most of the administrative head quarters are located in this district. A comparatively higher concentration of educational institutions, including Kabul University and the University of Islamic Sciences, is found to be in the third district. 
Bagh-i-Bala, The High Garden, which figures extensively in the story of Kabul is located in fourth district. The Institute of Polytechnic is located in fifth district. Kabul Museum and the historical palace of Darulaman are a part of sixth district. Bagh-i-Babur, Babur's Garden, the Jangalak Factories and Chilsitoon Palace with its beautiful spacious gardens are located in seventh district. The historical Bala Hissar-High Fortress (the history of which is the history of Kabul city) is part of the eighth district. The concentration of the government employees is found to be in nineth district, as in this district the government has been building houses and distributing them to some of its employees. The most modern part of the city with very luxurious houses - Wazir Akbar Khan Mena is located in the tenth district. Eleventh district is a completely residential area. Schools and industry are, generally, spread out in the city, but the main centre of industry is located in the eastern part of the city - Industrial Region of Pol-1-Charkhi.

The population of Kabul city according to 1986 population census was $1,301,289$, which account for more than half of the country's urban population. The population of this city has been growing very rapidly (more than 5 percent per annum during 1979-86 period).

obviously this rapid growth of the population affect las already affected) soclo-economic development of the city. For proper development planning, an assesment of the extent of utilization of human resources, which appears to be the most strategic 
and critical among the various key resource factors (human, physical and financial), is very necessary. The development goals of Afghanistan includes the maximum possible utilization of human resources in productive activity and the fullest possible development of the skills, knowledge and capacities of the labour force. If these goals are pursued, other goals such as economic growth, higher level of living and more equitable distribution of income are thought to be the likely consequences.

1.4. ORGANISATION OF THE STUDY

Essentially this study is subdivided into seven chapters. Chapter one, the present chapter, has dealt with the background of the study, objectives and an introduction of the study area. Chapter II describes the data sources and mathodology, besides a brief review of literature. Chapter III gives detailed profile of the Kabul city. The results of the analysis of data are presented in the following three chapters. Chapter IV deals with activity rates and working life table, Chapter $v$ deals with composition of economically active population and Chapter VI deals with under-utilization of labour. Chapter VII, the last one, gives a summary, certain conclusions and some recommendations.

Finally appendices and details of references cited in the text are put at the end of the study. 


\section{CHAPTER ॥}

DATA, METHODOLOGY

AND

REVIEW OF LITERATURE 


\subsection{INTRODUCTION}

Economically active population, according to the 1986 census of Kabul city, comprises all persons of either sex who were practically engaged in the production of economic goods and services or those who were seeking participation in such activities during the reference perlod (one week prior to the census). It includes both civilian labour force and armed forces and both employed and unemployed persons. Employed persons are those who worked in any occupation durIng the reference period or those who had a job in which they had already worked but from which they were temporarily absent because of 1llness, injury, temporary ceasation of work or bad weather. This oategory also inoludes unpaid family workers defined as those members of the household who put in atleast one-third of their working hours for the economic activity of the household without any wage or salary. It also includes those students who, besides study in educational institutions, were engaged in some economic activity.

Unemployed consists of all persons who were not working during the reference period; but who were seeking work for pay or profit including those who were seeking work for the first time.

\subsection{DATA SOURCES AND LIMITATIONS}

Most of the statistical information in this study are taken from official publications. The main source is the Population Census of Kabul City, 1986. This is supplemented wherever possible with data taken from the 1979 Population Census of Afghanistan and Population Census of Greater Kabul, 1965. Some relevant Information from the Statistical Year Books (1979 to 1988) are also used. 
But all these sources could provide only very limited data. The census of 1986 provided infarmation on economioally active population classified by age, sex, occupation, Industry, educational attainment, marital status (for women only) and migration status. But cross classifications are very few and avallable classifications are not very detailed to help to make any indepth study. Most of them were two-way classifications. The collected data were not properly processed, tabulated or published. The 1986 census, for example, collected information on fertility and martality of Kabul city; but they are not published yet (Central Statistics Office, 1988 : 19). It should also be mentioned in this context that the problems of accurate data collection (like linguistic diversity, poorly developed transportation and communication network, high level of 1111 teracy, religious taboo against enquirying about female members, etc.l; was compounded by the war that has existed in Afghanistan since 1979.

Data from different sources are taken (fully knowing that they may not be directly comparable), only with a view to present an overall pattern and level. Reliability of the data could not be gauged. But it is hoped that this information will give a general picture which could serve as a starting point for analysis of economically active population in Kabul city.

As stated earlier, Tehran city data are used for comparison. Tehran data were taken from "National Census of Population and Housing, November 1976, Tehran Shahrestan, Markazi Ostan, Serial No.3, Statistical Centre of Iran, 1980". In this census, the economically active population and its related concepts were defined the same as that of 1986 census of Kabul city, mentioned above. The comparison of 1986 
data of Kabul city with 1976 data of Tehran city may be questioned. The justification for this lies in the fact that compared to Kabul, the latter city is much more developed and as such this comparison may help to show how closer Kabul city is to 1976 Tehran; for it is suspected that the 1986 Tehran may be way off comparison. Moreover, among comparable cities, only the data of Tehran, 1976 were avallable to the researcher. In the text, therefore, it should be nemembered that all data on Tehran relate only to 1976, even if it is not specifically mentioned.

\subsection{METHODOLOGY}

Gross tabulations wi 11 be frequently used in this study, depending upon the type of data avallable. Some indices also will be used. One such index is index of dissimilarity. It measures, for example, the occupational dissimilarity by gender. This index is computed as :-

$$
I D=\frac{\sum_{i=1}^{n}\left|o_{1 i}-o_{2 i}\right|}{2}
$$

where $\mathrm{O}_{1}$ and $\mathrm{O}_{2}$ are the proportion of population 1 and 2 respectively who are located in occupation 1. The index can take only value between zero (identical distribution) and 1 (non-overlapping distribution) (United Nations, 1980).

To measure the extent of sex labelling in occupational categories, the index used is the one used by the United Nations (1985), called the index of female employment and is computed as follows :-

$$
I_{1}=\frac{P_{f 1}}{P_{f}} \times 100
$$

where $P_{f i}$ is the percentage of females employed in occupation 1 and 
$P_{f}$ is the share of female workers to total workers. This index shows the share of female workers in any given occupation in relation to female share in the total employment. A value of one hundred, less than one hundred and more than one hundred means, the share of women in that occupation is equal to less than or more than their share in the total employment in that order.

To find out the relative difference in occupational division for migrant and non-migrant workers of Kabul c1ty, the Index given by Zachariah (1968) is used which is calculated as follows :Index $=\frac{\text { Proportion among migrants }- \text { Proportion among non-migrants }}{\text { Average proportion among migrants and non-migrants }} \times 100$ If the value of this index is 100 or more, the difference is considered to be very high, if it lies between 75 and 99 the difference is high. But, if its value falls between 25 and 74 or below 25 the difference is considered to be low and very low respectively.

In order to flind the expectation of active 11 fe, rate of entry into labour force and rate of loss from labour force, the life table technique will be used. A working 11 fe table will show the joint effect of age-specific mortality rate and age-specific labour force participation rate on the length of working life. The working life table will a lso give an idea of how many new entries to expect, how long they will remain in the labour force after they enter and when they will leave. Working life table can either be complete or abridged depending on whether one uses single years or grouped years. It is an extension of life table. Whereas the latter gives the average number of years a person may expect to live at birth or any given age, the former gives the expected number of remaining years of working life to a person of any given' age. In this study, an abridged working life table will be 
constructed using quinqunnial age groups.

The methodology adopted is the one given by the United Nations (1968). In this connection, UNFPA-NCSO (1977), Gnanasekaran and Montigny (1971) and Hawley et.al (1974) are also referred to.

The basic assumptions involved in working life table construction are the following:-

(1) Only members of stationary population may enter or leave the labour force, migration is ruled out.

(11) Losses from the labour force prior to the maximum participation rate are only due to deaths; and losses after the maximum participation rate includes both deaths and retirements.

The various functions of the working iffe table are explained

below:

1. $x$ (column 1): age.

2. $5_{x}$ (column 2): This is the economic activity rate within each age group.

3. $W_{x}$ (column 3): This is the age-specific economic activity rate for the beginning age of each age group which are obtained by averaging the rates for successive pairs of 5 year activity rate given in column 2 .

4. $1_{x}$ (column 4): This is the number of persons who survive to exact age $x$ from a group of 100,000 persons born alive.

5. $1 W_{X}$ (column 5) : This represents the number of persons who survive and are in the labour force at each exact age $x$ from 100,000 persons born alive. These values are directly computed by multiplying activity rates (column 3 ) by the corresponding values of survivors (column 4 ) that is,

$$
1 w_{x}=\left(I_{x}\right) \cdot\left(w_{x}\right)
$$

6. $5_{x}$ (column 6) : This is the ${ }_{5}{ }^{2}$ function of the abridged life table, the stationary population in each age interval representing the number of persons who would be alive within each age group in a hypothetical 
population replenished annually by a constant number of 100,000 live birth and subject to the given age-specific rates of mortality.

7. $5^{L W_{x}}$ (column 7) : This shows the number in the stationary population expected to be in the labour force at each age interval. This is obtained by the relationship:

$$
5^{L}=\left(L_{x}^{L}\right) \cdot\left(S^{W}\right)
$$

8. $T_{X}$ (column 8) : This is the $T_{x}$ column of the 11 fe table, representing the remaining total number of man-years that would be lived by the survivors at the given year of age and in all the following years. It may be expressed as -

$$
T_{x i}=\sum_{x=1}^{\infty}\left(5^{L} \cdot x\right)
$$

9. TWx (column 9): This represents the total number of man-years lived

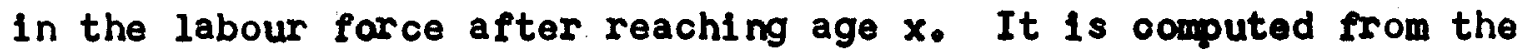
values in column 7 as follows:

$$
T W_{x 1}=\sum_{x=1}^{\infty}\left({ }_{5} W_{x}\right)
$$

10. $e_{x}^{0}$ (column 10): This to the average life expectancy of persons in the stationary population, measured from exact years of age, that is,

$$
e_{x}^{0}=\frac{T_{x}}{I_{x}}
$$

11. $e^{\mathrm{W}} \mathrm{Wx}$ (column 11): This is the average number of working 11 fe remaining at exact year of age $x$, that is -

$$
e^{o} W_{x}=\frac{T W_{x}}{l_{x}}
$$

\section{Other relevant statistics from working life table}

12. Average number of inactive ilfe (column 12): The difference between mean expectancy of life and mean expectancy of working life will give the mean number of inactive life, 1.e.,

$$
e_{x}^{0}-e^{0} w_{x}
$$


13. Average remaining number of years of labour farce activity (column 13) : This is a straight forward computation for ages beyond the age at which the activity rate is the maximum, i.e.,

$$
\frac{T W x}{1 W x}
$$

For ages till the age at which maximum aotivity rate is, some modification is required. Since only the working life of persons who have already entered the labour force is of interest here, the contribution of future entrants should be eliminated. This is obtained by eliminating what the labour force would have been if the worker rate had already gained the maximum level. Thus the activity rate, for the younger ages are replaced by hypothetical maximum activity rate (i.e., the maximum activity rate in the table). Accordingly, $1 W x,{ }_{5}^{L W_{x}}$ and $T W_{x}$ should be recalculated. Thus, using the recalculated figures and the same formula (TW $\dot{x}^{\circ} l W_{x}$ ) the avarage remaining number of years of labour force activity can be computed for ages below the age of maximum activity rate.

14. Column 14 shows the net increase or decrease in the number of economically active population which is obtalned by taking the successive differences of column 5 .

15. Accession or entry to labour force (column 17): This is the net number of persons entering the labour force (Ax) in the interval between two successive years of age (ar between two successive age groups) after allowing for mortality. For this, the mortality rate between successive years of age (or between successive age groups) is required. This is obtained by applying the ilfe table mortality rate to the economically active stationary population in each age interval, on the assumption of equal mortality rates for economically active and inactive persons. The life table mortality rate used in this calculation is obtained as -

$$
q_{x}=\frac{1_{x}-1 x+5}{5^{L} x} \quad x 1000
$$

The multiplication of this $q_{x}$ values in each group by ${ }_{5}{ }^{L W}$ gives the first estimate of $A_{x}$. This first estimate should be adjusted on a pro-rata basis to obtain the accession (entry) rate $\left(a_{x}\right)$ per 
1000 inactive persons among the survivors of the stationary population (column 18); and it is computed as -

$$
a_{x}=\frac{A x}{5^{L}-5^{L / x}} \times 1000
$$

16. Loss to labour force due to death : The number of deaths of economically active persons $Q_{x}^{d}$ (column 15) is obtained, first by applying the life table mortality rate to economically active stationary population in each age interval (since this is 5 year rate and it is applied to a five year age group of the population, the result must be divided by five) and then is adjusted on a pro-rata basis (the same adjustment is done for net entries to labour force). The death rate per 1000 active population (column 16) is computed as -

$$
q_{x}^{d}=\frac{Q_{x}^{d}}{5^{L W_{x}}} \times 1000
$$

17. Loss to the labour farce from retirements: For the computation of net retirements (column 19) a net retirement rate (column 20) for each age interval is applied to the total stationary population. These retirement rates are obtained by taking differences between specific activity rates for successive ages after the age at which the activity rate is maximum (prior to this point these differences give the net entry rate) - (Since this is a five year rate and it is applied to a 5 year age group, the result must be divided by five) and then is adjusted on a pro-rata basis. Thus, the retirement rate per 1000 active population (column 20) is computed as :-

$\frac{\text { Number of net retir ements }}{5^{L W} x}$

18. Similarly, the crude rates of replacement of the labour force by entries and its depletion by deaths and retirements are derived by applying the age-specific rates from the working 11 fe table to the figures for corresponding age groups in the actual labour force and in active population and summing up the result for all ages. The division of the total estimated number of entries into the labour' force, total estimated number of annual retirements from 
labour force and the total estimated number of annual loss by death, by the total number of labour force gives the annual crude rates of entries, retirements and loss by death respectively.

The replacement rate which can be interpreted as a sort of rate of natural increase of the labour force, is obtained as the difference between the crude rate of entries and the sum of the crude rates of retirements and loss by death.

The replacement ratio which may be interpreted as an index of the pressure on the labour market represented by the demands of entering workers for jobs, in proportion to the number of jobs being vacated by retirement and death - is calculated as follows :-

Annual number of entries into the

Replacement Ratio $=\frac{\text { labour force }}{\begin{array}{l}\text { Annual number of retirements }+ \text { Annual } \\ \text { number of losses by death }\end{array}} \times 100$

\subsection{REVIEW OF LITERATLRE}

The basic demographic determinants of labour force, like the relative size of the labour force in proportion to the population and various measures of participation in the labour farce by specific characteristics are important in determining the productive capacity of the country. The labour force participation rate relate to the demographic characteristics of the labour force as an aspect of its qualitative development as well as of the arganization of the society and the style of life (Durand, 1975). In a study like the present one, therefore, it is necessary to describe the type of labour participation expected in an urban set-up like that of Kabul. As such, some theoritical formulations supplemented by stude es in labour force is the main concern of this section.

While dealing with the linkages between population and labour force, Stolnitz (1974) described that urbanization will tend to reduce male activity rates at the extremes of working life span. In fact, 
several other studies also (Turnham 1971, Standing 1978, Sheehan 1979) found the truncation of work participation rate at younger and older age groups with economic development. Urban areas being better developed than rural areas, the need and opportunity for work among these age groups are found to be low. Another effect of urbanization is that it tends to ralse that fraction of female labour farce who work away from the family (Stolnitz, 1974). One would, thus, expect to find a reduction in young and older age group activity rates in Kabul city during 1965-86 period. Moreover, an increase in the percentage of women workers in modern sector activity is also expected.

To elaborate on the Sheehan study (1979) it was found that in Khartoun currently married women had lower participation rate whereas women who are themselves head of the households have higher rates. In other words, women who have to fend for themselves are found to be participating more in the labour force. Thus, in Kabul city, it is expected that a higher proportion of those who are not currently married will have high participation rate. Furthermore, Khartoum study has found that the presence of children depress female participation rate. Thus, Kabul city with a high fertility rate one would expect low female participation. Education is another factor affecting female activity rate (Sheehan 1979, Peek, 1979). Educated women were found to participate more and that should be true for Kabul ol ty also.

A modern city is a territorial unit which arises with the separation of certain activities from primary production and their concentration at points where their performance can be most satisfactory from the point of view of the largest number of persons. The city's population is, therefore, always a dependent group. A continuous exchange of goods and services with the villages and towns round 
about is necessary to the very existance of a city (Hawley,1950). In other words, ofty will take care of its primary needs through its interaction with rural areas.

These transformations in the industrial structure will lead to concomitant changes in the occupational structure as well (Singelmann and Brouning, 1980).

The United Nations study on migration, population growth and employment in metropolitan areas of selected developing countries (1985) had occupational composition of metropolital employment and extent of sexual division of labour as two of the specified five objectives. The examination of cities from 26 countries for 1950, 1960, 1970 and 1980 revealed that production workers made the largest category. Over the period there was decline in this category in favour of modern sector jobs like professional, technical and related, clerical and related,etc. This shift from blue color to white color workers was found to occur in the course of economic development. The large share of production related work in cities was also found in Bangalore (Rao \& Tewar1, 1979). One would expect that Kabul city like many other cities in less developed countries might have been developing over the years and that there will be an over concentration of workers in production and related activities; but this concentration will be more in 1965 than in 1986.

The United Nations (1985) has also found that among the female workers many will be in the professional and clerical job. They have found it to be more so in predominantly Muslim metropolitan areas like Algier, Damascus, etc. This is another pattern that could be expected in Kabul city.

Studies relating female labour farce participation and fertility are many. For example, in North-western Iran, Good et.al (1980) 
found that there was a general and almost monotonic decrease in the number of living children, children ever born and ideal number of children with an increase in the rank of occupational group. Members of modern occupational groups had considerably lower children ever born and the difference between number of living children and ideal number of children was significantly smaller. They also found that of all indicators of social status they have considered, viz. income, education, occupation of husband, ownership of modern items and ownership of agricultural land, education had one of the most powerful and consistent effect on the number of living chlldren and the women's education shows the strongest and most consistent relationship to two intermediate variables - use of contraception and age at marriage. This is to be expected as education and occupation are two important components of status and that they are highly positively correlated.

Gamrah (1980) observed the same pattern in Cairo where mothers In the occupational groups of technical and professional works, directors and managers and clerical work had significantly lower marital fertility, while the women working in sales and commerce had the highest fertility among economically active women. However, economically active women, on the whole, had lower fertility than inactive women.

The study of Mexico city was not much different either. Smith (1981) found that the wife's potential wage had a significant negative effect on traditional sector work and a significant positive effect on modern sector work. He also found that the potential wage had a significant negative effect on family size. The results of his study suggest expansion of that type of female employment as a means of lowering fertility in less developed countries which could raise the opportunities cost of children. According to him, the decline in traditional sector employment opportunities as modernization occur is one of the factors leading 
to the fertility deoline In less developed oountries.

With the help of Jakarta data, Sethuraman (1976) has shown

that the fast growing cities in less developed countries are gaining lot of workers who pursue informal sector activities as they all can not get work in modern sector.

This tendency has been substantiated by other studies also. For instance, Jatoba (1989) found that in urban Brazil, nearly 23 percent of urban non-agricultural workers were working in informal sector in 1979. Similarly, in urban Costa Rica (Pollack, 1989), 38 percent and in urban Panama (Camazon et.al., 1989), 23 percent of the total workers were engaged in informal sector activities. This is a situation that is being increasingly accepted as a part of urban employment, particularly in less developed countries and Kabul city cannot be an exception. Even though Kabul city census data are not good enough to examine this aspect, it is felt that most of them will be classified into trade and/or production related work increasing its magnitude. Labour under utilization is very common in many of the labour surplus less developed economies. But neither its magnitude nor its nature is properly understood mainly because of the difficulty in defining them. Under utilization can take the form of open unemployment, underemployment or 'di scouraged workers'. Open unemployment refers to persons who are actively seeking job and is comparatively easy to obtain data than the other two types. Underemployment, be it in terms of skill or time, is aimore widespread symptom of under-utilization than open unemployment (Smith, 1971). But the informations are not easily available. Still warse is the situation th respect to 'discouraged workers'. They are the people who are avallable for work but not actively seeking job as they find the labour market to be too tight for them to 
get any job (Standing, 1978). All the same, studies have given some Idea of its magnitude in urban areas. In Hong Kong (Fan, 1975) in 1971, 72000 persons were unemployed. Two-thirds of the unemployed were found to be males and one-third females. In 1983, in Brazil (Jatoba, 1989), 64 percent were unemployed with 6.6 percent for males and 5.9 percent for females. Unemployment was found to be very high for the youngsters aged 10-17 and 18-24 (11.4\% and 11\% respectively) and the same was high for males than for females. In 1980, in Guatemala (Arturo et.al, 1989) city, open unemployment rate was 3.7 percent, Open unemployment and di scouraged workers accounted for 9.2 percent and visible underemployment was 7.6 percent. Thus, together the under-utilization was to the tune of 16.8 percent. In 1983 (Camazon et.al., 1989) the unemployment rate in urban Panama was 5.7 percent. The unemployment rate in Greater Santiago (Pollack and Uthaff, 1989) in 1985 was 17.7 percent. This was a great come-down from early 1980 s when it was more than 30 per cent. In Manila in 1985 (Alonzo, 1989), the unemployment rate was 22 percent.

The differences in manitude should not bother anyone as definitions are always different from country to country. The one factor to bear in mind here is that a high degree of under-utilization of labour has become characteristic of many less-developed countries, particularly in urban areas and that open unemployment alone is not a sufficient measure for it. All the same, data constraints make one rely on open unemployment information alone which should be seen as the absolute minimum prevailing situation. This is in this way that the unemployment section of this study should be seen. 


\section{CHAPTER III}

PROFILE OF KABUL CITY 


\subsection{INTRCDUCTION}

Profile, as the word 'profl 1e' suggests, provides a brief descriptive account of the characteristics wich will give the reader an 1 dea about the general characteristics of the area under study. The major features covered here are: the size, distribution and growth, nationality and mother tongue, eex-age structure, marital status distribution, household composition, literaoy and educational attalnment, fertility, mortality and migration of the population of Kabul ofty.

\subsection{SIZE, DISTRIBUTION AND GRONTH OF THE POPULATION}

According to 1986 Census of Kabul oity, the total population of the elty was 1,301,289 which is 51 percent of the total estimated urban population of the country. 1 The density of population for the city as a whole was 4,373 persons per sq.Km. In 1979 whioh has increased to 6,109 persons per sq.Km. In 1986. The percentage distribution of the populas tion among the eleven districts along with growth is shown in Table 3.1

Table 3.1 The percentage distribution and the growth rate of the population of Kabul city by districts in 1979 and 1986

\begin{tabular}{|c|c|c|c|c|c|c|c|c|c|c|c|c|}
\hline \multirow{2}{*}{ Year } & \multicolumn{11}{|c|}{ D1striots } & \multirow[b]{2}{*}{ Total } \\
\hline & 1 & 2 & 3 & 4 & 5 & 6 & 7 & 8 & 9 & 10 & 11 & \\
\hline 1979 & 10.8 & 4.9 & 10.4 & 6.8 & 7.4 & 13.8 & 12.0 & 11.3 & $6: 1$ & 9.0 & 9.5 & $\begin{array}{l}100,0 \\
(931400)\end{array}$ \\
\hline 1986 & 6.5 & 3.7 & 6.6 & 8.7 & 9.8 & 11.7 & 11.3 & 7.9 & 9.4 & 8.2 & 16.2 & $\begin{array}{c}100.0 \\
(1301289)\end{array}$ \\
\hline $\begin{array}{l}\text { Percent } \\
\text { change } \\
\text { durling } \\
1979-86\end{array}$ & 15.8 & 3.3 & -1168 & 7.9 & 87.0 & 18.4 & 58.0 & 2.1 & 15.2 & 26.2 & 139.8 & 39.7 \\
\hline
\end{tabular}

Source: Central Statistical Offloe, Final Results of the 1986 Population Census of Kabul City, Vol.I, P.12, Kabul, 1988. Last row computed from P.10, same sourow.

1 According to 1965 (Maroh 1986-Warch 1987) Stati st1cal Year Book of Afghanistan the total estimated (on the basis of 1979 populabion Census) settlod population of the country in 1986 mas 14928,8 thousands of which 2562.3 thousands wore living in urban centres. 
As Table 3.1 shows the population of Kabul city is not distributed equally among the eleven districts. The eleventh district, with 16 percent of the total population is the most populated area of the city, while the second district with a share of 3.7 percent of the total population is the least populated part of the city. It is suspected that the differential in the distribution of the population of the city is mainly because of the differences in areas, the number of the residential units and socio-economic conditions. But the area of each of the districts are not avallable.

The population of Kabul olty has Inoreased by 37.0 thousand persons during June 1979 to December 1986 period giving an annual growth rate of 5.2 percent. (However, the growth rate of population was much mare during $1965-79$ period - 8.1 percent per annum). Females were growIng much faster than the males, the average annual growth rate for the farmer being 5.8 peroent and that of the later being 4.8 percent. The situation prevaling among the females may be the natural situation; whereas the low growth rate of males is an artificial situation created by the peculiar political situation that prevalled in the city during the reference period which led to an increase in the adult male outmigration. In other words, it is a highly fertile population grouling rapidly which, if uncheoked, will double itself before the end of the present century.

But, as 18 seen in Table 3.1, the growth of the population differs from district to district. While some of the districts like eleventh and nineth had a very high total net growth, some others like first, third and elghth had a negative growth $1.0 .$, the number of their population has decreased during 1979-86 period. The main reason for this negative population growth is the movement of population - either 
out of the city or to other districts in the city. For example, the old Kabul clty was located in the first district. According to now plan of the city, some of its houses were destroyed by municipality and the land were used for the construction of roads and markets. Thus the residents of those areas were shifted to some other districts. The decrease in the percentage population of the third and eighth distriots was mainly because of out-migration elther because of political considerations (leading mainly to family out-migration) or because of milltary law leadIng to adult male out-migration.

One reason for the larger share of population observed in the eleventh district could be its area. It has a large area./ Moreover, the municipality has recently distributed land at low cost enabling the homeless people to construct houses. The number of houses in this district constitutes 14.02 peroent of the total number of houses $(129,718)$ of Kabul city which 1 s considerably higher than that of other districts. The district's location also is important. It is located away from the centre of the city and hence has comparatively low rent attracting more people. The main reason for a large share of the ninth district in total city population was the construction of new houses (apartments) by government in this district which was distributed to some of the government employees (including those who were living in other districts before) during 1979-86. Another major attraction of these two districts is that they are situated along the highway - the eleventh district along the high-way from the North of the country and the ninth district along the highway from the East of the country. Accessibility to highway is an important factor in population concentration (Hawley, 1950).

$2 /$ Personal observation. 


\subsection{NATIONALITY AND MOTHER TONGUE}

Nationality, according to the 1986 population census, refers to a group of people who have common culture, language and religious customs.

More than half $(57.1 \%)$ of the total population living in Kabul clty belonged to Tajek nationality (see Table 3.2).

Table 3.2 The percentage distribution of population by nationality and sex, Kabul city, 1986.

\begin{tabular}{lccc}
\hline Nationality & Male & Female & Total \\
\hline Pushtoon & 25.1 & 24.8 & 24.9 \\
Tajek & 56.8 & 57.5 & 57.1 \\
Hazara & 12.8 & 12.5 & 12.6 \\
Uzbak & 0.9 & 0.7 & 0.8 \\
Turkman & 0.5 & 0.5 & 0.5 \\
Nooristani & 0.1 & 0.1 & 0.1 \\
Balooch & 0.1 & 0.1 & 0.1 \\
Hindu-Sikh & 1.0 & 1.1 & 1.1 \\
Others & 2.7 & 2.7 & 2.7 \\
& & & 100.0 \\
Total & 100.0 & 100.0 & $(1301289)$ \\
\hline
\end{tabular}

Source: Same as Table 3.1, p.24.

Though it is true that the majority of the citizens of Kabul city are Tajek, the proportion shown seems to be exceptionally high. It is felt that some error might have crept into the data because of the nonunderstanding of the meaning of nationality by some and also because of the possibility of inadvertently classifying some of the Dari-speaking population as Tajek. $3 /$

3/ All Tajeks are Dar1-speaking people; but all people who speak Dari are not Tajeks. 
About a quarter of the city population belonged to Pushtoon nationality and slightly over a tenth of the population belonged to Hazara. These three nationalities together account for almost 95 per. cent of the Kabul city population.

Table 3.3, where the distribution of the population by naticine ality in different districts is given, reveals that about 70 percenc of the Pushtoon nationality were living in five districts, namely $9,11,5,8$ and 7. Simllarly, 60 percent of the Tajek population vere concentrating In five districts $(11,7,4,9 \& 10)$; and about farty-three percent of Hazw ara was in the sixth district. Nearly 50 percent of Nooristani was riw ported as the residents of three districts, namely 11,10 and 9. Whilo the majority of Balooch were living in the tenth, fifth and first disew tricts, almost all of Hindu-sikh nationality were the residents of the fourth, tenth, second and first districts. In sum, the tendency seews to be for people of the same culture to be together rather than spreading out in different parts.

The mother tongue of a person is defined as that language which was the usual language of his household during his childhood. "itu children who were not able to speak at the time of census, the usual language of the conversation of their household was considered as tireir wother tongue.

The percentage distribution of the population by mother tongut is presented in Table 3.4 and it reveals that the mother tongue of nearly threefurourth of the population was entered as Dari and another 23 poi... cent as Pushto accounting for 97.4 percent of population.

It has to be noted in this context that the Hazaragi language, an Indopendant language, has not been taken in the classifioation of the population by mother tongue. It is possible that they got included li. 


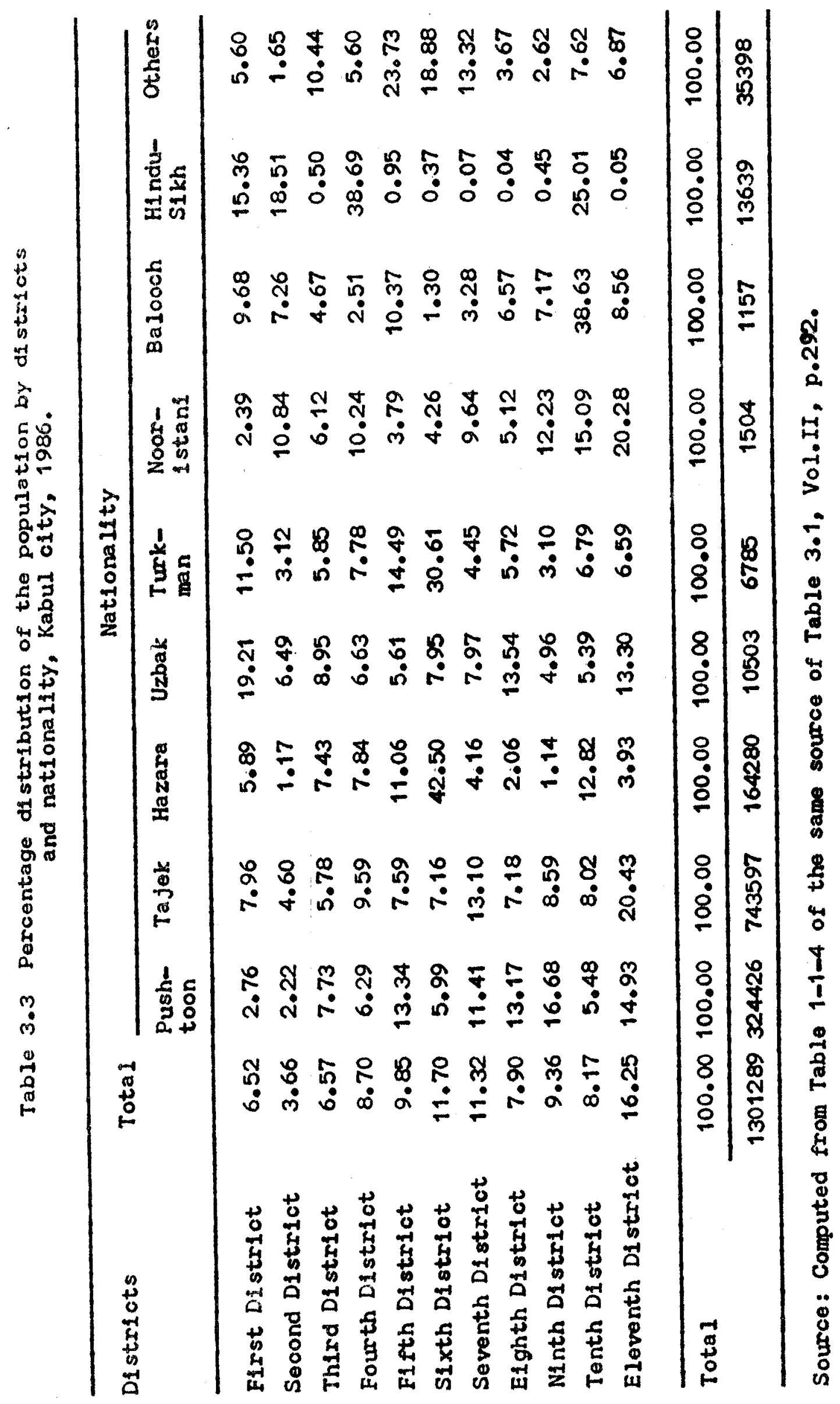


the Dari group ralsing its proportion to a very high level.

Table 3.4 The percentage distribution of the population by mother tongue, Kabul city, 1986.

\begin{tabular}{|c|c|c|c|c|c|c|c|c|c|c|}
\hline & \multicolumn{9}{|c|}{ Mother Tongue } & \multirow{2}{*}{ Total } \\
\hline & Pushto & Dar1 & $\begin{array}{l}\text { Uz- } \\
\text { bak1 }\end{array}$ & $\begin{array}{l}\text { Tuk- } \\
\text { mani }\end{array}$ & $\begin{array}{l}\text { Noor- } \\
1 \text { stant }\end{array}$ & $\begin{array}{l}\text { Bal- } \\
\text { oo- } \\
\text { ch1 }\end{array}$ & $\begin{array}{l}\text { Hin- } \\
\text { di \& } \\
\text { Pun- } \\
\text { Jabi }\end{array}$ & $\begin{array}{l}\text { Other } \\
\text { Inter- } \\
\text { nal } \\
\text { lang- } \\
\text { uages }\end{array}$ & $\begin{array}{l}\text { Other } \\
\text { fore- } \\
\text { lgn } \\
\text { lang- } \\
\text { uages }\end{array}$ & \\
\hline $\begin{array}{l}\% \text { of } \\
\text { Popu- } \\
\text { la- } \\
\text { tion }\end{array}$ & 22.6 & 74.8 & 0.8 & 0.9 & 0.1 & 0.1 & 1.0 & 0.2 & 0.0 & $\begin{array}{l}100.0 \\
(1301289)\end{array}$ \\
\hline
\end{tabular}

Source: Same as Table 3.1, p.26.

\subsection{SEX-AGE STRUCTURE OF THE POPULATION}

\subsubsection{Sex Structure}

The masculinity proportion of the 1986 population was 50.95 , showing an excess of nearly 25000 males over females. But, this, when compared to the 1965 situation of Kabul city, is considerably low, as in 1965 the excess was to the tune of 52000. The low masculinity prom portion of Kabul city population can be also seen by comparing it with that of Tehran city $-52,6$ in 1976.

The sex ratio for the olty for 1965,1979 and 1986 works out to be 127,110 and 104 respectively. The main reason is the out-migration of adult males aged 15-39 during 1979-86 period because of the military law according to whioh male population aged $18-39$ must serve 5-7 years in army in two phases. Those who were not willing to serve in army, in that circumstances, were leaving the city. Thes abnormality of the sex ratio of the population of Kabul ofty can be seen by comparing the sex ratio of the age group 15-39 in 1986 with that in 
1965, a normal situation. In 1965, there were 136 males per 100 females in this age group compared to 83 in 1986 (Table 3.5).

Table 3.5 Sex ratio of the population of Kabul city by broad age group in 1965 and 1986

\begin{tabular}{ccc}
\hline \multirow{2}{*}{ Age Group } & \multicolumn{2}{c}{ Sex Ratio } \\
\cline { 2 - 3 } & 1965 & 1986 \\
\hline $0-14$ & 110.9 & 107.9 \\
$15-39$ & 136.4 & 83.0 \\
$40-64$ & 151.8 & 136.3 \\
$65+$ & 183.3 & 177.7 \\
\hline Tota 1 & 127.1 & 103.9 \\
\hline
\end{tabular}

Sources:

1) Computed from Table of p.12, Population of Greater Kabul 1965. Statistical Department, Mini stry of Planning, Kabul, 1968.

2) Computed from the Tables $2-2-2$ to $3-2-2$ of the same source of Table 3.1, Vol.II, pp.269-270.

The sex ratio of 1965 represents peace time sex ratio of a rapidly growing urban centre in any of less developed countries, while the sex ratio of 1986 is a peculiar situation created by war.

A comparison of the sex ratio of the population of Tehran city in 1976, which was 110,95 for total population and 114.31 for the age group 15-39, also indicates the abnormality of the sex ratio of Kabul city population in 1986.

The district-wise differences in sex ratio is given in Table 3.6 for 1979 and 1986 as for 1965 the same data is not available. On the whole, except in district 1, all other districts have shown a decline in sex ratio during the period under consideration.

The low sex ratio in the 15-39 age group comes out very clear. ly for each district in the city (Table 3.7). 


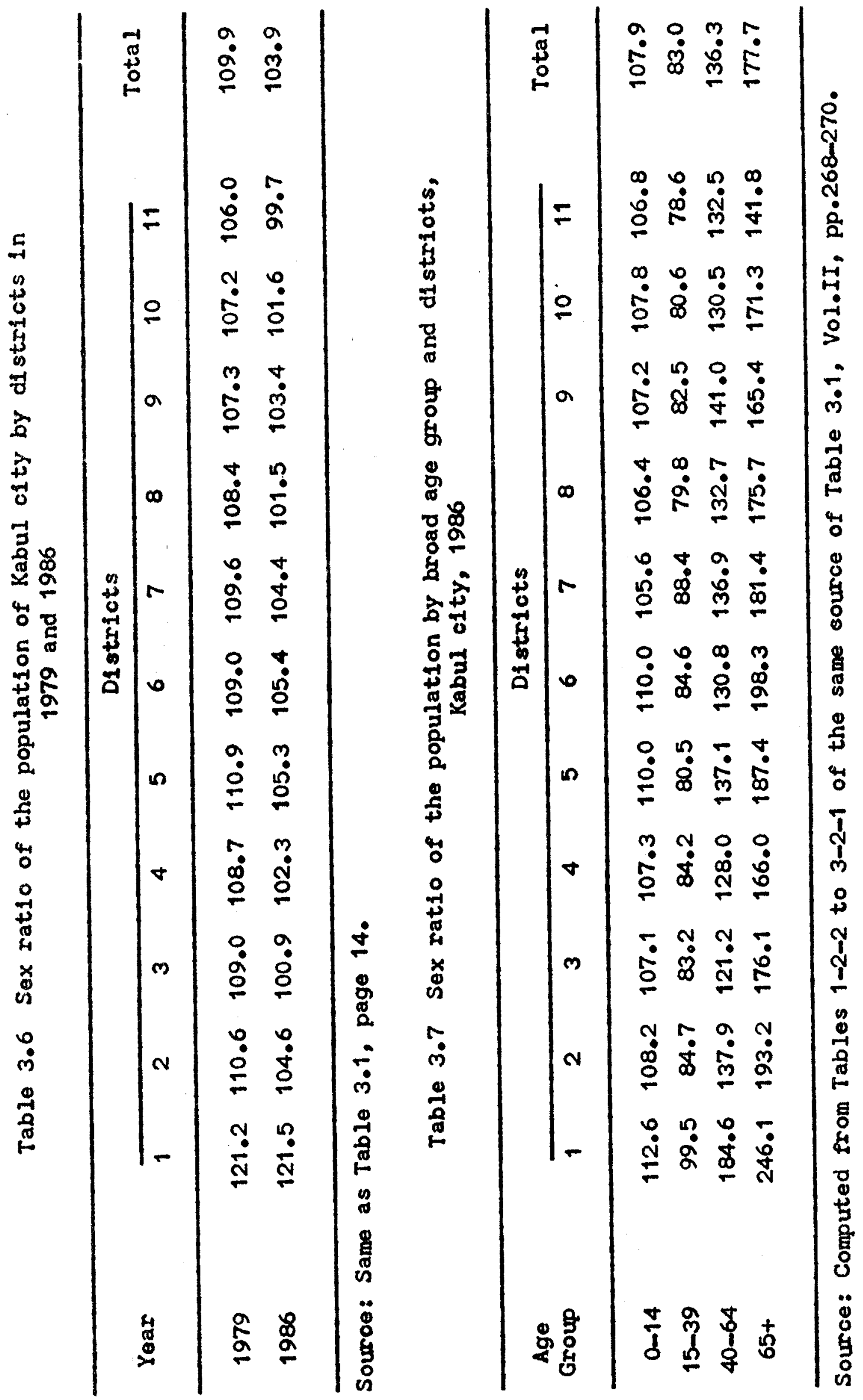




\subsubsection{Age Structure}

The age structure of Kabul city population (Table 3.8) has Indicated a very young population in 1986 with slightly over 48 percent of the total population falling the 0-14 year age group. The population aged 65 years and above formed only less than 3 percent. The very young age structure of the 1986 population of Kabul city also can be seen by comparing it with that of Tehran city, as only 36.8 percent of the total population of Tehran city in 1976 was under 15 years of age and the share of the population of 65 years and above, in total, was 3.3 percent.

Table 3.8 The percentage distribution of the population of Kabul ofty by broad age group and sex in 1965 and 1986

\begin{tabular}{|c|c|c|c|c|c|c|}
\hline \multirow{2}{*}{$\begin{array}{c}\text { Age } \\
\text { Group }\end{array}$} & \multicolumn{2}{|c|}{ Male } & \multicolumn{2}{|c|}{ Female } & \multicolumn{2}{|c|}{ Total } \\
\hline & 1965 & 1986 & 1965 & 1986 & 1965 & 1986 \\
\hline $0-14$ & 42.0 & 49.3 & 48.2 & 47.5 & 44.8 & 48.4 \\
\hline $15-39$ & 39.1 & 29.7 & 36.4 & 37.1 & 37.9 & 33.3 \\
\hline $40-64$ & 15.3 & 17.6 & 12.9 & 13.4 & 14.2 & 15.6 \\
\hline $65 t$ & 3.6 & 3.4 & 2.5 & 2.0 & 3.1 & 2.7 \\
\hline Total & $\begin{array}{c}100.0 \\
(243600)\end{array}$ & $\begin{array}{c}100.0 \\
(663036)\end{array}$ & $\begin{array}{c}100.0 \\
(191600)\end{array}$ & $\begin{array}{c}100.0 \\
(638253)\end{array}$ & $\begin{array}{c}100.0 \\
(435200)\end{array}$ & $\begin{array}{c}100.0 \\
(1301289)\end{array}$ \\
\hline
\end{tabular}

Source: Same as Table 3.5 .

Between 1965 and 1986 major difference is observed only among male population. The share of children has increased and that of adults in the 15-39 age group has decreased. (In this context it should be wentioned that in magnitude all the age group has gained population during this period as one would expect in a less developed country). This may be because of the adult male out-migration mentioned in the context of 
sex composition. Consequently the wedian age of the male population has cowe down erom 18.79 years in 1965 to 15.37 years in 1986. The corresponding median age for females has remalned more or less the same for the two years under consideration - a nominal increase from 16.10 to 16.21 yoars.

A comparison of median age of total, male and female population with the corresponding figures for Tehran city, again, shows the very young population of Kabul city in 1986. As in Tehran city, the comparative median age for 1976 worked out to be $20.53,20.85$ and 20.16 years respectively for total males and females.

With such a young age structure one would expect a high age dependency ratio 4 for 1986 than for 1965 and the data has borne this out. The age dependency rat10 in 1965 was 92 compared to 104.7 in 1986. This shows that adult population in the city was more than dependent age group population in 1965 and the situation got reversed In 1986. Tehran city in 1976 had only an age dependenoy ratio of 67 which is even lesser than the 1965 situation in Kabul city.

The age pyramid given below in figure 3.1 also wakes the agosex composition of the population of Kabul city in 1986 abundently clear, and its comparison with the age pyramid of Tehran city (figure 3.2) brings out very olearly the abnormality of the age structure of the wales of Kabul city in the 15-39 age group which is the result of ma le adult out-migration due to military law mentioned earlier.

4 The age dependency ratio represents the ratio of the combined child population (under 15 years of age) and aged population (population 65 years and ever) to the population of working age (population aged 15-64) generally expressed as percontage. 

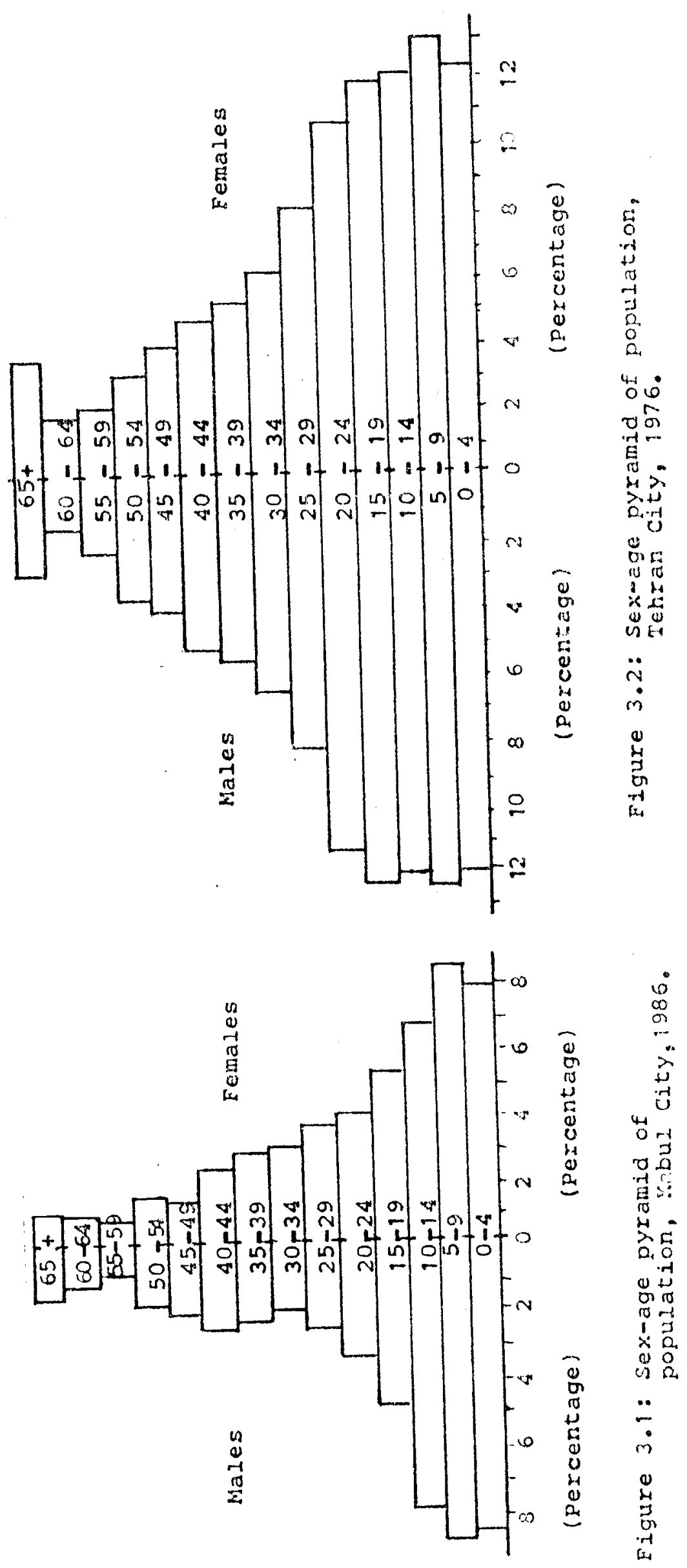


\subsection{MARITAL STATUS}

Marital status information is provided for population aged 10 years and above in the census and there were 861,490 persons in this categary. Among them 44.62 percent were never married, 50.88 per cent were currently marrled, 4.43 percent were widowed and 0.03 percent was divorced (Table 3.9). The corresponding flgures for Tehran city works

Table 3.9 Percentage distribution of the population aged 10 years and above by marltal status and sex,

Kabul city, 1986

\begin{tabular}{lccc}
\hline $\begin{array}{l}\text { Marital } \\
\text { Status }\end{array}$ & Male & Female & Total \\
\hline $\begin{array}{l}\text { Never married } \\
\begin{array}{l}\text { Currently } \\
\text { warrled }\end{array}\end{array}$ & 49.10 & 40.00 & 44.62 \\
$\begin{array}{l}\text { Widowed } \\
\text { Divorced }\end{array}$ & 1.50 & 52.46 & 50.88 \\
Not reported & 0.02 & 7.45 & 4.43 \\
\hline Total & 0.04 & 0.04 & 0.03 \\
& 100.00 & 0.05 & 0.04 \\
\hline
\end{tabular}

Source: Computed from Tables $1-1-3$ to $3-1-3$ of the same source of Table 3.1, Vol.II, Pp.271-273.

out to be $41.57,53.11,4.35$ and 0.97 respectively in 1976 - showing a higher proportion of currently married and divorced population. It should be mentioned in this context that the higher proportion of never married and widowed in Kabul city is the outcome of the peculiar situation created by war.

The almost negligible figure of divorce $(0.03$ which is even 32 times less than that of Tehran city - 0.97) indicates the stability of famlly life in Kabul c1ty. But, of the 280 divoroed persons in the clty, slightly more than two-thirds (67.5\%) were females. The same is 
true for Tehran oity where, in 1976, out of the 33129 divorced persons, 69.36 percent were females. This could be beoause most of the divorced men remarry; whereas women will not do so. This situation may be a reflection of the society's disapproval of divorce and their tendency to hold women responsible for the divorce resulting in their finding it difficult to remarry. It could also be possible that women do not want to remarry for fear of their earlier experiences being repeated.

An examination of the age-specific marital status distribution has shown that the proportion married in the 10-14 year age group is very negligible (less than 1\%); whereas in the 15-19 age group 4 percent of males and 20 percent of females were married (see Table 3.10 ).

On the whole, the proportion remaining unmarried in each age group was high among males compared to females as in generally found in any less developed countries. On the other hand, the proportion widowed was higher among women in each age group compared to that of men in the same age group for which cultural explanation has already been given. A comparison of married population in the 15-19 age group with 1965 population census of Greater Kabul shows a considerable increase in the age at marriage. The percentage of married population in this age group during 1965-1986 decreased from $7.1,40.0$ and 20.0 to $4.3,19.8$ and 12.3 for males, females and total population respectively. The same is true for total population (all age groups) where the percentage of married persons for males, females and total population decreased from $58.5,73.7$ and 64.8 in 1965 to $49.3,52.2$ and 50.9 in 1986 .

Notice that the decline of the proportion married among males was only from 7 percent to 4 percent while that of females was from 40 to 20 percent for the 15-19 age group persons. In other wards, the increaso in age at marriage which refiects from this information could be 


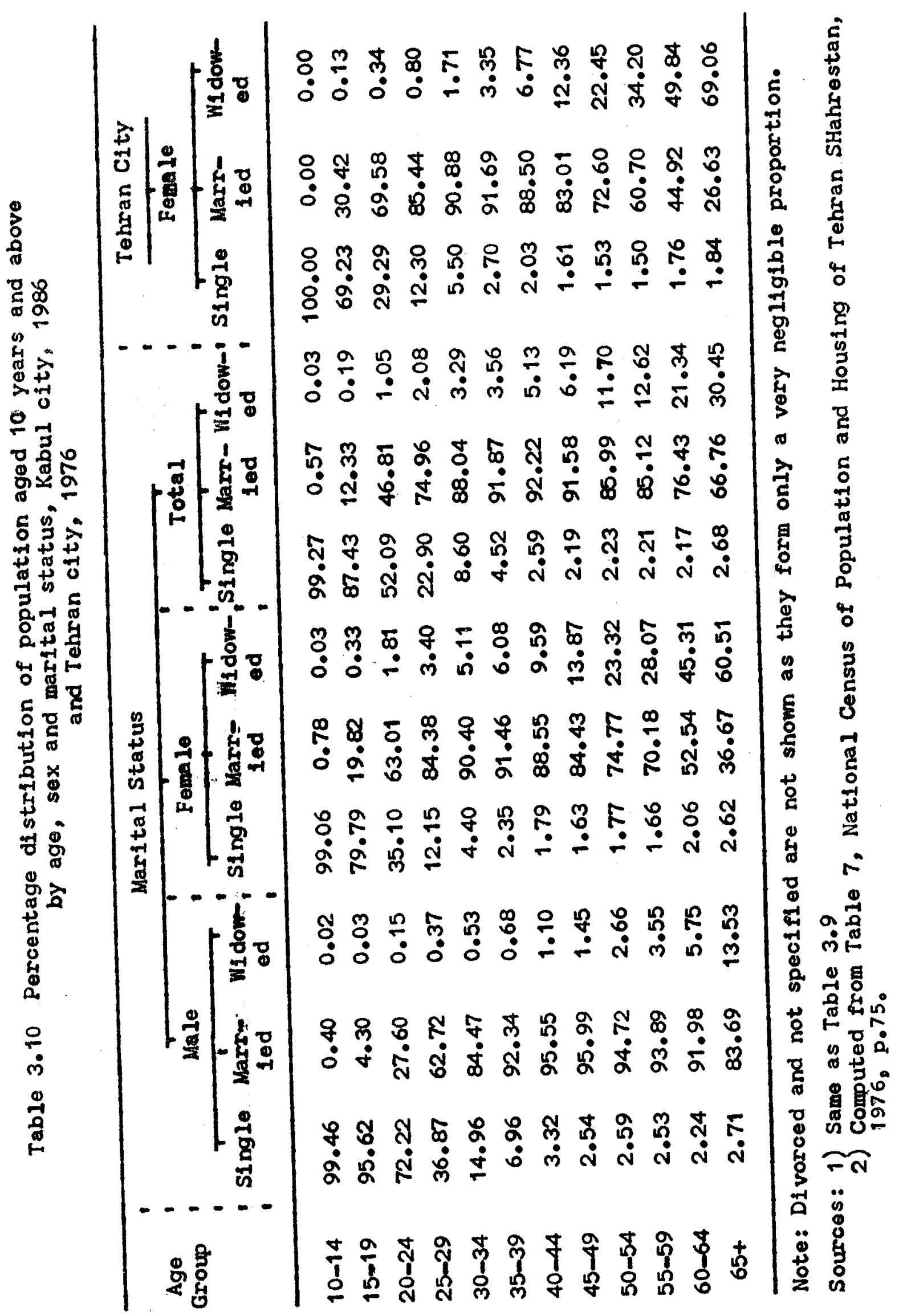


due to a decline in the eligible bachelors who have out-migrated due to polltical/military considerations.

Even those aged 20-24 years, only 28 percent of males and 63 percent of females were married. A comparison of the percentage of married females in the 15-19 and 20-24 age groups with the corresponding figures of Tehran city - 30.4 percent and 69.2 percent - gives a higher age at marriage for Kabul oity.

Among the older group, 65 years and over, nearly 61 percent of women and about 14 percent of men were widowed. The proportion female widowed in each age group in the age interval of 15 to 39 years was very high compared to the female widowed in the same age group of Tehran clty (Table 3.10). This again reflects the effect of war which usually increases the deaths of males of prime age.

\subsection{HOUSEHOLD COMPOSITION}

A household in the 1986 census oonsists of one or more persons who are living together, have common (total or partial) inoome and expenditure and usually are taking food together.

The number of households of Kabul clty in 1986 was 196,499 and the average size of the household was 6.62 persons (very large compared to the average household size of Tehran city which was only 4.61 persons in 1976). A comparison of these figures with that of previous censuses of 1965 and 1979 shows that the average annual growth rate of households during 1965-79 and 1979-86 was 5.65 and 4.10 percent respectively. It has been pointed out earlier that the population growth rate was 8.1 percent during 1965-79 and 5.2 percent during 1979-86. But, still the average household size has increased from 6.1 in 1979 to 6.6 in 1986. The same was around 6.2 in 1965. Again, checking up with the 
trough observed on the adult males in the sex-age pyramid, one is bound to think that if other things remalned constant the average household size in 1986 would have been much more than the observed 6.6 persons. The percentage distribution of the households by the size of household ( $T a b l e ~ 3.11$ ) shows large households to be very common in Kabul city•

Table 3.11 The percentage distribution of the households by the size of household, Kabul city, 1986.

\begin{tabular}{lllllllllll}
\hline & \multicolumn{8}{c}{ Size of Household } & (number of persons) \\
\hline 1 & 2 & 3 & 4 & 5 & 6 & 7 & 8 & 9 & $10-14$ & $15+$
\end{tabular}

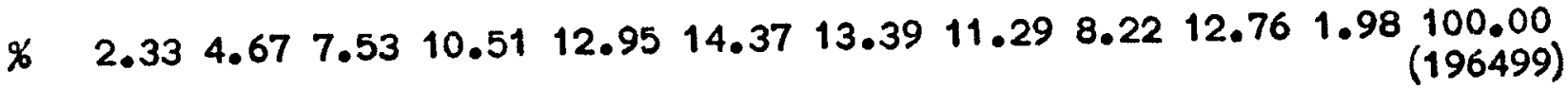

Source: Computed from the Table $0-2-1$ of the same source of Table 3.1, Vol.II, P.228.

Nearly two-thirds of the households have 6 persons or more. Two possible reasons can be given for this. The first and most important is the high birth rate prevailing in the country. In this oontext it should be pointed out that nearly 70 percent of the total households are nuclear households (Central Statistics Office, 1988). Secondly, the economic difficulty in setting up new households coupled with the socio-cultural acceptance of joint/extended family living arrangements contributed to the prevalence of large household size.

The average household size of the different districts also were wore or less the same, 6-7 persons, except in the first district where it was only 5 persons (Table 3.12 ).

Information about the percentage distribution of households by district and size of household is given in Table 3.13. . 


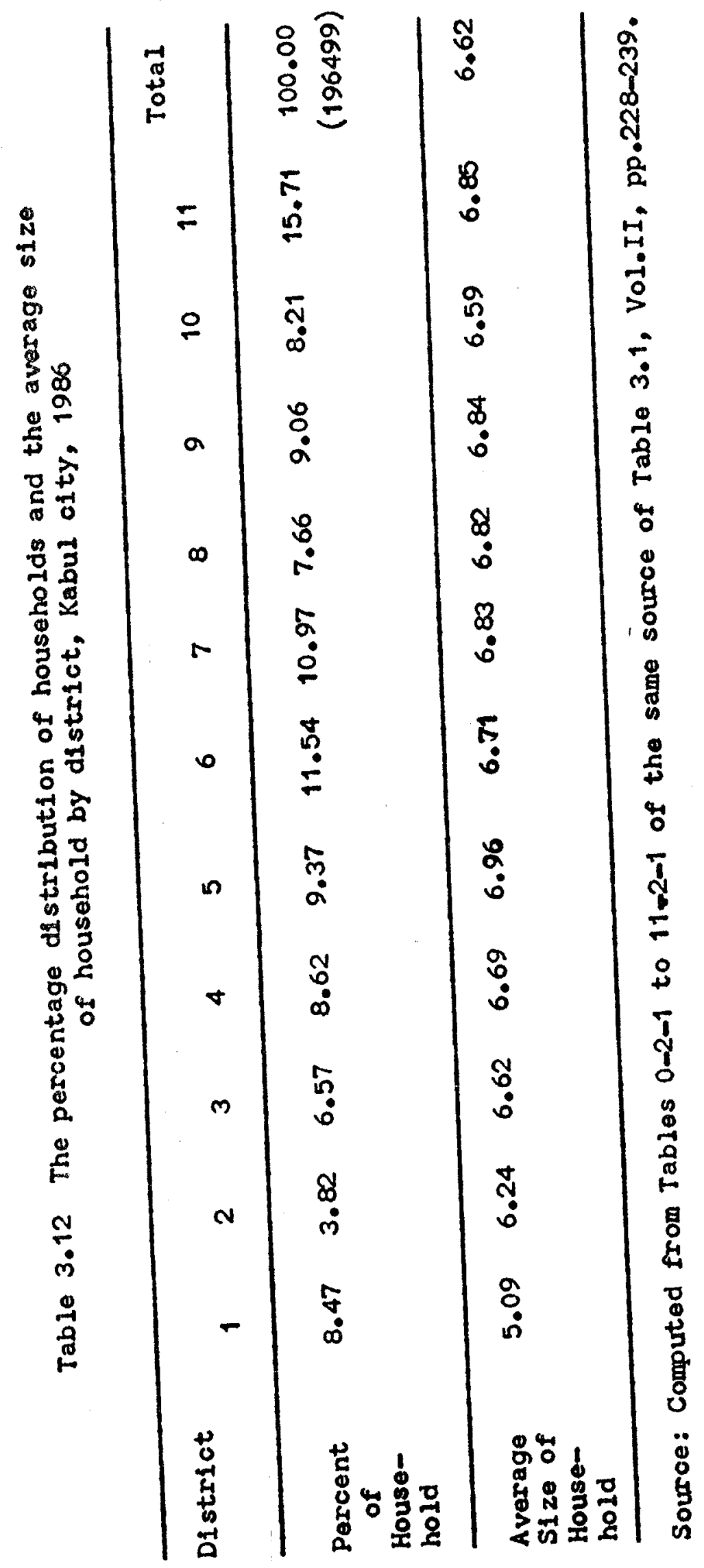




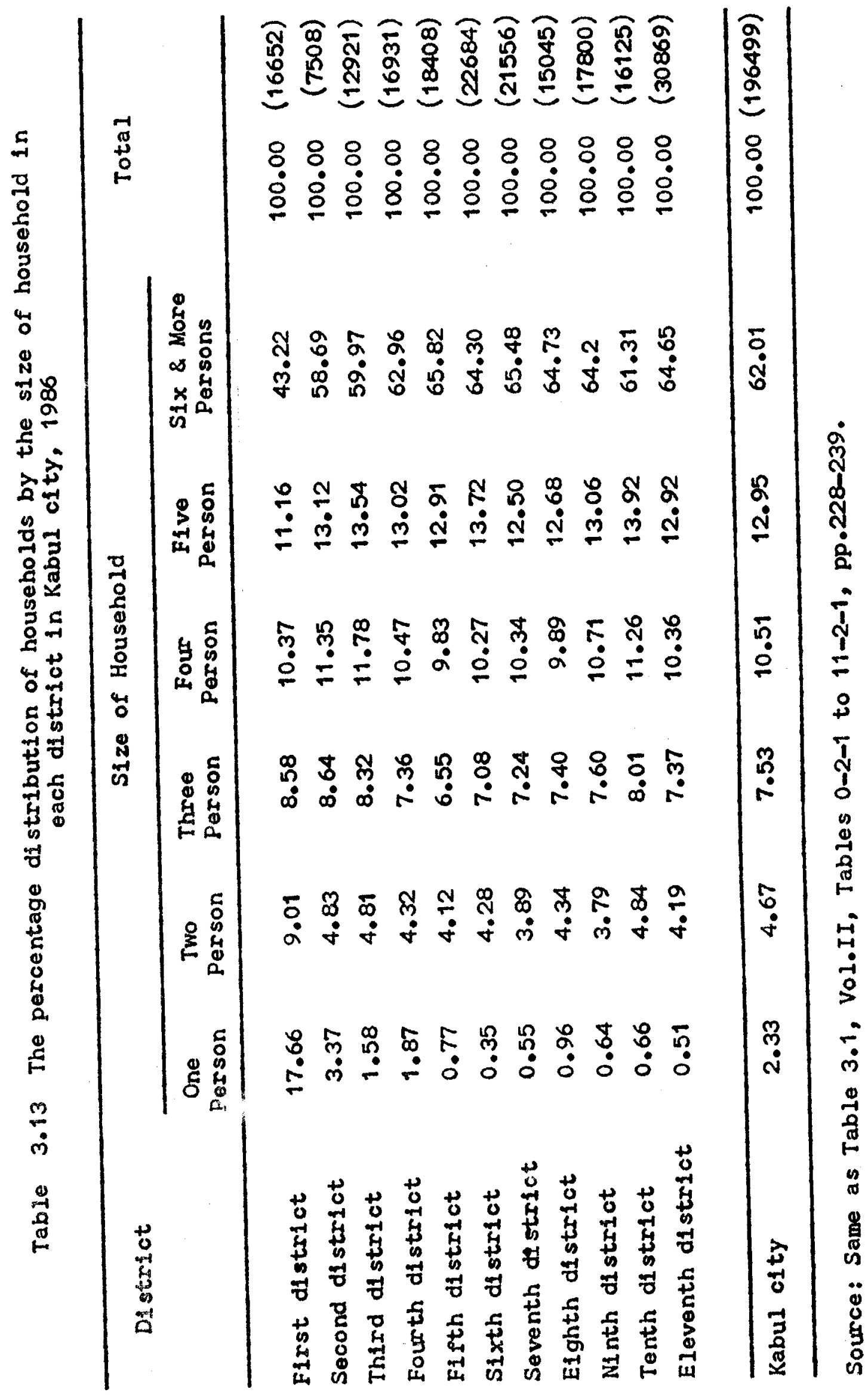


One to two person households are very few in all the districts except in the first district where they constituted about 27 percent. This, couplod with the comparatively small average household size in this district, makes it kind different from other districts. One reason for this could be the type of residential units available for the inhabitants of this district. Fifty-eight percent of the total households in this district had only one room whereas a large number of households in other districts had two or more rooms (see Table 3.14). More than 35 percent of all houses in other districts had three or more rooms and first district had, in this category, only 16 percent.

Table 3.14 The percentage distribution of households by the number of rooms available in each district

in Kabul city, 1986

\begin{tabular}{|c|c|c|c|c|c|c|c|c|c|c|c|c|}
\hline $\begin{array}{l}\text { Dist- } \\
\text { rict }\end{array}$ & 1 & 2 & 3 & 4 & 5 & 6 & 7 & 8 & 9 & 10 & 11 & $\begin{array}{l}\text { Kabul } \\
\text { City }\end{array}$ \\
\hline
\end{tabular}

$1 \quad 58.1 \quad 32.025 .326 .222 .6 \quad 27.020 .522 .6 \quad 18.826 .324 .627 .01$

1 or $2 \quad 83.7 \quad 64.959 .0 \quad 58.1 \quad 56.7 \quad 63.8 \quad 57.0 \quad 56.0 \quad 51.6 \quad 59.457 .0 \quad 60.17$

$3+\quad 16.335 .141 .041 .943 .3 \quad 36.243 .044 .048 .4 \quad 40.643 .039 .8$

Source: Computed from Tables $0-4-14$ to 11-4-14 of the same source of Table 3.1, Vol.II, pp.378-389.

\subsection{LITERACY AND EDUCATIONAL ATTAINMENT}

\subsubsection{Literacy}

Literate, according to the census of Kabul city, is a person Who can read, write and understand the meaning of any simple sentence. The crude literacy rate of the total population of Kabul city works out to be 42.2 percent in 1986. There was a considerable differ- 
ence between male and female 11 teracy rates : 53.7 and 30.3 percent respectively. The effective 11 teracy rate $5 /$ for the total population of the city was 50.6 percent : 64.3 percent for males and 36.4 percent for females. A comparison of the effective literacy rates with the corresponding rates that prevalled in 1965 (32.4, 42.3 and 19.2 percent respectively for total male and female population) shows a comparatively slow growth of literacy in the city.

A comparison of the effective literacy rate of the 1986 population with the corresponding rate of the population of Tehran city 73.0 percent in 1976, also show the low level of literacy in Kabul city. Though a considerable difference between male and female literacy rates prevalled also in Tehran oity (males: 79.3 , females: 66.0), the proportion of literate females is much higher in Tehran city. In other words, while the ilterate females of Tehran city farmed 74.5 percent of the literate nales, the corresponding figure for Kabul city was only $54.4 \%$. Literacy differential among the different nationalities living In Kabul city (Table 3.15) has shown that the numerically minority comin unities like Nooristani, Hindus and Uzbak had more literate population (71.68\%, 66.74\% and $60.0 \%$ respectively). The reason for this is that these minorities in Kabul city have comparatively favourable economic condition which enable them to attend school. Male-female literacy differential is considerable for all nationalities. Among them this gap is highest for the nationality of Pushtoon and is lowest for Uzbak. This difference again is a reflection of cultural situation.

$5 /$ Percentage of literate population per 100, population aged five years and above. 


$$
-: 46:-
$$

Table 3.15 Percentage distribution of population aged 10 years and above by nationality, literacy and sex,

Kabul city, 1986

\begin{tabular}{lccc}
\hline Nationality & $\begin{array}{c}\text { Male } \\
\text { Literate }\end{array}$ & $\begin{array}{c}\text { Female } \\
\text { Lterate }\end{array}$ & $\begin{array}{c}\text { Total } \\
\text { Literate }\end{array}$ \\
\hline Pushtoon & 75.63 & 35.58 & 56.05 \\
Tajek & 71.16 & 41.86 & 56.61 \\
Hazara & 55.68 & 20.52 & 38.69 \\
Uzbak & 67.79 & 49.42 & 60.00 \\
Turkmen & 62.23 & 26.21 & 45.75 \\
Nooristani & 85.46 & 56.93 & 71.68 \\
Hindu-Sikh & 81.25 & 51.93 & 66.74 \\
Others & 74.74 & 42.07 & 58.72 \\
\hline Total & 70.48 & 37.92 & 54.45 \\
\hline
\end{tabular}

Source: Computed from Tables 1-2-4 to 3-2-4 of the same source of Table 3.1, Vol.II, pp.295-297.

The effective ilteracy rate for the different districts was found to be different (Table 3.16). Third district with 61 percent 11terates had the highest literacy rate and highest sex ratio of literates. Kabul University and also comparatively more number of schools are located in this district. The first district with 40.17 percent had the last position. In this regard, the majority of the male inhabitants of the first district are traditionally shopkeepers and sales workers.

Table 3.16 Effective literacy rates by districts, Kabul oity, 1986

\begin{tabular}{llclc}
\hline Districts & Male & Female & Total & F/M $\times 100$ \\
\hline First district & 49.19 & 28.92 & 40.17 & 47.18 \\
Second district & 65.44 & 41.39 & 53.72 & 60.17 \\
Third district & $\mathbf{7 4 . 5 7}$ & 47.40 & 61.00 & 63.41 \\
Fourth district & 68.29 & 43.63 & 56.08 & 62.64 \\
Fifth district & 61.25 & 27.99 & 45.05 & 43.40 \\
Sixth district & 55.99 & 24.72 & 40.84 & 41.51 \\
Seventh district & 66.33 & 35.17 & 51.11 & 50.69 \\
Eighth district & 66.46 & 38.51 & 52.56 & 57.34 \\
Ninth district & 60.57 & 31.73 & 46.40 & 50.53 \\
Tenth district & 66.93 & 41.71 & 54.37 & 61.75 \\
Eleventh distriot & $\mathbf{7 1 . 0 8}$ & 42.2 & 56.57 & 60.09 \\
Total (Kabul city) & 64.33 & 36.37 & 50.62 & 54.39 \\
\hline
\end{tabular}

Source: Computed from Table 0-1-9 of the same source of Table 3.1, Vol. II, p. 322 . 


\subsubsection{School Enrolment}

The results of 1986 census shows that out of a total population aged 5 years and above, about 280 thousand were enrolled in different levels of educational institutions (25.8\%), in which the share of females was 40.2 . This is low compared to the corresponding figures prevalled in 1976 in Tehran city. As the school enrolled population of Tehran city formed 34.5 percent of the total population aged 5 years and above, the share of females was 47.2 percent.

Enrolled among males aged 5 years and above is 30.3 percent and the corresponding figure for females works out to be 21.2 percent (though it shows some difference, the difference could be considerable if there was no adult male out-migration from the city)which, compared to that of Tehran oity -36.0 percent and 32.8 percent, again shows the lov level of enrolment and higher male-female differential.

The percentage distribution of the school enrolled population in different grades (Table 3.17) shows that 47.4 percent of those who

Table 3.17 The percentage distribution of the sex-wise population enrolled in school by grade, Kabul city, 1986.

\begin{tabular}{llllll}
\hline \multirow{2}{*}{ Sex } & \multicolumn{5}{c}{ Grade } \\
\cline { 2 - 6 } & $1-5$ & $6-8$ & $9-12$ & $13+$ & Total \\
\hline Male & 47.8 & 26.3 & 19.0 & 6.9 & $100.0(167360)$ \\
Female & 46.8 & 24.0 & 22.3 & 6.9 & $100.0(112660)$ \\
\hline Total & 47.4 & 25.4 & 20.3 & 6.9 & $100.0(280020)$ \\
\hline
\end{tabular}

Source: Same as Table 3.1, p.29.

are currently enrolled are in the 1-5 grade. This is also true for Tehran city where about 46 percent of the total enrolled population fall in this category. 


\subsubsection{Educational Attainment}

The percentage of the literate population aged 10 years and above by educational attainment is given in Table 3.18. This table shows that the majority of the literate population was currently in school. This is to be expected as nearly half the population are below 15 years of age. This figure for females exceeds that of males. The reason behind this may be the out-migration of the school-going male population, especially after finishing medium school.

The male-female differential in each level of education is also observed. In each educational category, the share of males was higher than that of females. This, again, is an expected pattern as in less developed countries the need for female education is seldom felt. For people with economic problems educating boys will be more meaningful and rewarding than girls who are seen more as home makers than bread winners. This is supplemented by the cultural feeling which is less favourable for female education.

Highly educated people form only a very small proportion of the ilterate population even among males. This can be clearly seen by comparing the share of the post-graduates in literate population of Kabul city -1.31 percent for males, 0.32 percent for females and 0.97 percent for total with the corresponding figures of Tehran city which works out to be $2.11,0.49$ and 1.43 percent respectively in 1976. It is suspected that a good proportion of highly educated people have migrated to other countries because of adverse political situation. 


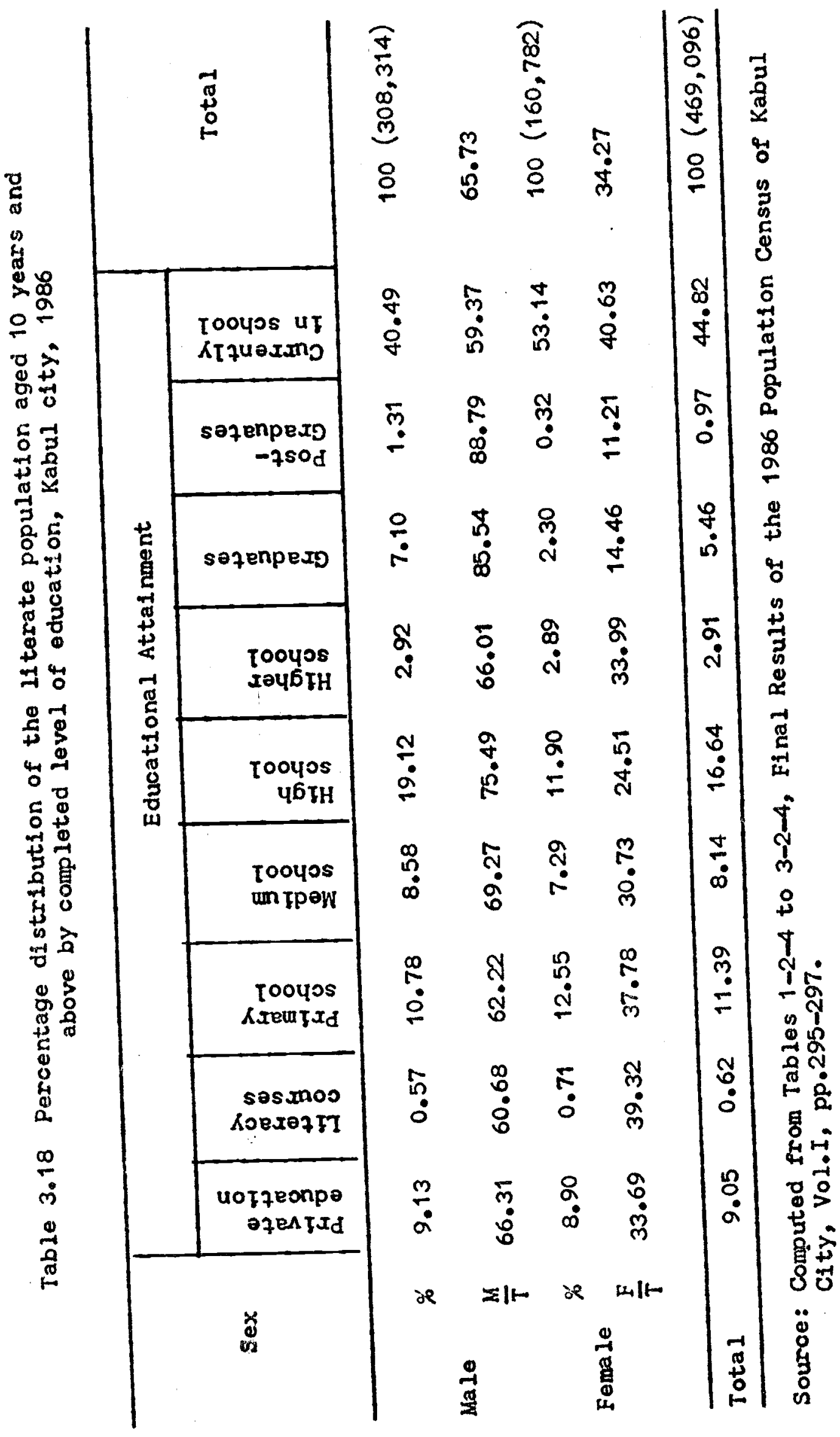




\subsection{FERTILITY, MCRTALITY AND MIGRATION}

\subsubsection{Fert111ty}

It is not possible to obtain the correct level of fertility and mortality of the population of Kabul city, as even the simplest statistical data required for such an estimation are not avallable. Using Rele's Method (1967) of estimation of Gross Reproduction Rate (GRR) and Crude Birth Rate (CBR) from age-sex distribution, in this section, an attempt is made to estimate, roughly, these measures for this city. The reason for selecting this method is that it needs only age-sex distribution of population and a rough estimate of life expeca tancy of birth $\left(e_{0}^{\circ}\right)$ [for Kabul oity 1 t $1 \mathrm{~s}$ assumed to be 50 years] which are avallable for Kabul city. Moreover, this method does not assume the population to be stable, quasi stable or closed to migration. It 1s, therefore, useful for estimating fertility levels for subnational population. $6 /$ The results of the caloulation is given in Table 3.19. The crude birth rate for the city as a whole works out to be nearly 42 and the total fertility rate around 6 . Rele's Method is based on child-women ratio and in most countries $0-4$ children are a gross under-estimation (UN, 1956). As such the figures given above could be on the lower side. In other words, actual CBR and Total Fertility Rate (TFR) could be more than the estimated figure. These figures show that fertility level is not only higher than the urban fertility of many developing countries, but it is also higher than the rural fertility of some developing countries. For example, the rural CBR of Indi a in 1986 was 34.2 and the rural Hindus and Muslims had a

6/ For a technical discussion of its wider application, see J.R. Rele, Fertility Analysis Through Extension of Stable Population Concepts, ly, 1967. 
Table 3.19 Fertility indices by districts, Kabul city, 1986

Fertility Indices

District

\begin{tabular}{llll}
\hline CWR & GRR & TFR & CER
\end{tabular}

\begin{tabular}{lllll}
\hline First district & 0.76664 & 2.95 & 6.05 & 36.83 \\
Second district & 0.64570 & 2.49 & 5.10 & 36.42 \\
Third district & 0.63061 & 2.43 & 4.98 & 38.34 \\
Fourth district & 0.69568 & 2.68 & 5.49 & 40.41 \\
Fifth district & 0.82025 & 3.16 & 6.48 & 40.68 \\
Sixth district & 0.819315 & 3.16 & 6.47 & 39.98 \\
Seventh district & 0.78963 & 3.04 & 6.23 & 43.58 \\
Eighth district & 0.73254 & 2.82 & 5.78 & 40.06 \\
Ninth district & 0.86564 & 3.33 & 6.84 & 48.06 \\
Tenth district & 0.70166 & 2.70 & 5.54 & 40.52 \\
Eleventh distriot & 0.75825 & 2.92 & 5.99 & 44.09 \\
\hline Kabul city & 0.758366 & 2.92 & 5.99 & 41.55 \\
\hline
\end{tabular}

Source: CWR is computed from Tables 1-2-2 to 3-2-2 of the same source of Table 3.1, Vol.II, p.268-270.

Note $:$ CWR $=$ Child Women Ratio

GRR = Gross Reproduction Rate

GRR of 2.18 and 2.43 and a TFR of 4.48 and 5.01 respectively(Government of India, 1987-88). The universal marriage of women (proportion married $15-49: 86.21 \%$ ), low age at marriage (mean age at marriage for females : 17.33 years and for males : 17.53 years), low status of women, religious interest, low work participation (proportion of working women aged 10 years and above : 8 percent), low level of living and high infant mortality (more than 100) are the major factors responsible for this high level of fertility.

Distriot-wise differential (Table 3.19) shows that third dise trict with a TFR of about 5 has the lowest fertility level in the city. 
It should be noted that this district had the higher female literacy rate and the higher female economic activity rate. The negative relationship between these factors and fertility are well documented (see UN, 1973). The highest fertility rate of the ninth district could be due to low literacy level and low participation rate coupled with the highest proportion of working population in agriculture and related activities. More than 18 percent of the workers engaged in agriculture and related activities are residing in this district.

\subsubsection{Mortality}

As stated earlier, data on mortality of Kabul olty is not avallable. The available data for the oountry show a very high level of mortality. Crude Death Rate (CDR) was estimated to be 30 and life expectancy at birth $\left(e_{0}^{0}\right) 35$ years in Afghan Demographic Survey (197273). The corresponding figures in the first population census, 1979, worked out to be 28.67 and 40 years respectively. Infant Mortality Rate (IMR), according to 1979 census, was 182 for the country as a whole and 188.99 and 129.93 for rural and urban areas respectively. These rates are among the highest in the world. The United Nations estimate of IMR during 1980-85 for Afghanistan is still higher - 193 and $e_{0}^{0}=37$ (UN, 1987). Though the 1979 census gives a CDR of 7.3 for urban population, it is not a correct estimation as with this CDR, Afghan urban population must have a $e_{0}^{0}$ of atleast 60 years. But, it was only 49 (Rumzi, 1985). The results of a socio-health survey of Khair Khana (eleventh district) [1984] also reject the urban CDR of 1979 census. According to this survey, the CDR of eleventh district was found to be about 20 and IMR, 101. Since the report of this survey has mentioned that these figures colncide with the results of 
Multi-purpose Survey of Kabul City (1983) and Survey of Qalai Ahmad Khan (1984) and other surveys so far done in Kabul city, one could accept them for the city as a whole - showing a high level of mortal ity.

\subsubsection{Migration}

The 1986 Kabul City Census gives detalled information on migration. The place of birth data indicated that 40 percent of the 1986 population of Kabul city were migrants which is considerably highor than the corresponding figure - 29 percent of 1965 . About 7.64 percent ware born in Kabul province, 32.28 percent in other provinces and 0.14 percent born outside the country.

In figure 3.3 is given the percentage distribution of migrants by place of birth including only those provinces having a significant flow of people towards Kabul city. Parwan and Kabul provinces together account for slightly over two-fifths of the total migrants. The contribution of other provinces were comparatively low. All the same, where the contribution of Wardak, Logar, Ghazni and Laghman ware also taken into account, these six provinces together account for two-thirds of Kabul city total migrants. The remaining one-third of the raigrants carie from the remaining provinces.

Host of the migrants are short-distance migrants. Parwan is a neighbouring province of Kabul suffering from internal skirmishes forcm ing people to migrate. As this province has no boundary with any foreign country, emigration is not easy as in the case of some other provinces like Nangarhar, Paktia, Kandahar and Herat with similar circumstances which has resorted to emigration. 
$\%$

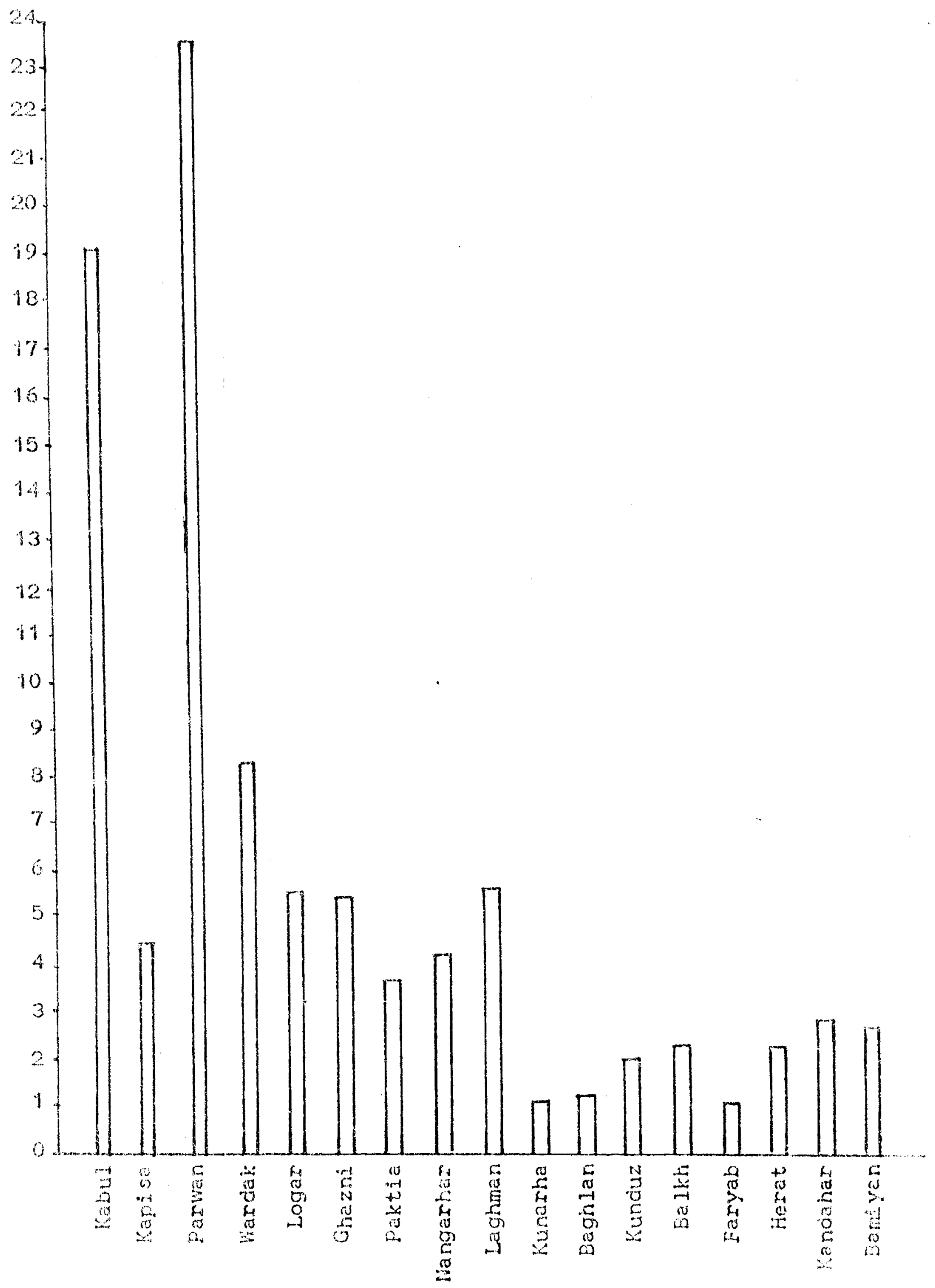

provinee of Birth

Ploure 3.3 fercentage Hgeants of Kabul City by Solective 


\section{a. Households by Number of Migrants}

The 1986 census data reveals that 69 percent of the total households in the clty had atleast one migrant in the family (Table 3.20) . Of the one person household, more than four-fifth were migrant households as one would expect. Further, nearly sixty percent of the total two persons households were all migrant households.

Distribution of the migrant population shows that except sixth district, a third or more of the population of each district were migrants. In the case of the eleventh district, 55 percent were migrants. Next in line comes fifth and ninth district in that order. This is to be expected as they form the entry points from different parts of the country - that is eleventh district is the entry point from North, fifth from West and ninth from East. The sixth district, with only 29 percent of migrant population has no easy access to any highway, thus attracting lesser migrants.

\section{b. Age Structure of Migrants}

The definition of migrant as a person enumerated in Kabul city, but born elsewhere, encompasses persons who came to the city at any time during their life time. Thus, it follows that the migrant's age distribution as recorded at the time of 1986 census enumeration may differ considerably from that at the time of in-migration to the city; and will have been modifled by factors such as (a) duration of residence in Kabul city, (b) age-selective out-migration or return migration and (c) age-selective mortality.

On the basis of the aval lability of data we shall concentrato in this section, only on age and sex composition of migrants and nonmigrants and the migrants' duration of residence in Kabul city. 


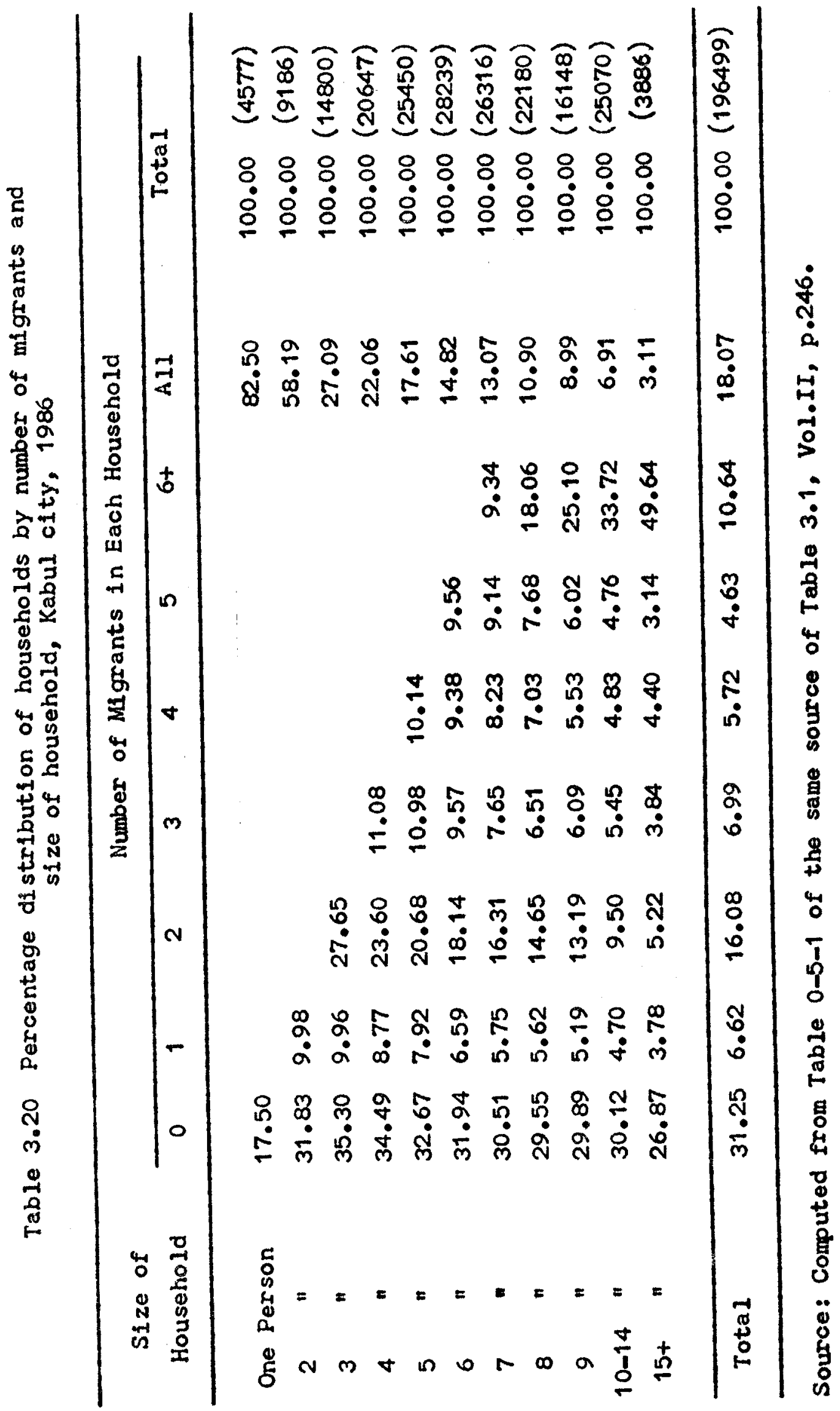


(i) Age and Sex Composition of Migrants and Non-migrants

The percentage distribution of life-time migrants in Kabul city by age and sex is given in Table 3.21. The excess of adolescents and young adults, generally observed among migrants to the cities in other developing countries, is not found among the migrants of Kabul city. For example, about 46 percent of the total migrants of Tehran city in 1976 were concentrated in the 20 years span covering ages 20 39 and 82.2 percent of them were in the prime working ages 15-59. Thesi percentages for Kabul city in 1986 were only 24 percent and 63 percent

Tablo 3.21 Percentage distribution of life-time migrants and non-migrants by age and sex, Kabul city, 1986

\begin{tabular}{|c|c|c|c|c|c|c|}
\hline \multirow{2}{*}{ Age } & \multicolumn{3}{|c|}{ Migrants } & \multicolumn{3}{|c|}{ Non-migrants } \\
\hline & Ma 10 & - Female & Total & Male & Female & Total \\
\hline $0-4$ & 3.05 & 3.10 & 3.07 & 26.31 & 25.85 & 26.08 \\
\hline $5-9$ & 11.43 & 11.09 & 11.27 & 21.73 & 20.90 & $21 \cdot 32$ \\
\hline $10-14$ & 15.16 & 13.67 & 14.44 & $15 \cdot 35$ & 14.03 & 14.69 \\
\hline $15-19$ & 9.72 & 10.86 & 10.27 & 9.33 & 10.37 & 9.85 \\
\hline $20-24$ & $7 \cdot 31$ & 9.62 & 8.43 & 6.18 & 7.21 & 6.69 \\
\hline $25-29$ & 6.55 & 9.35 & 7.90 & 3.94 & 5.06 & 4.50 \\
\hline $30-34$ & 5.74 & 9.33 & 7.47 & 2.46 & 3.76 & 3.10 \\
\hline $35-39$ & 6.88 & 8.60 & 7.71 & 3.06 & 3.46 & 3.26 \\
\hline $40-44$ & 8.03 & 7.91 & 7.97 & 3.00 & 2.67 & 2.84 \\
\hline $45-49$ & 7.10 & 4.31 & 5.76 & 2.23 & 1.66 & 1.95 \\
\hline $50-54$ & 6.15 & 4.6 & 5.40 & 1.72 & 1.72 & 1.72 \\
\hline $55-59$ & 3.24 & 1.83 & 2.56 & 1.13 & 0.81 & 0.97 \\
\hline $60+$ & 9.64 & 5.73 & 7.75 & 3.56 & 2.50 & 3.03 \\
\hline Unspecified & 0.00 & 0.00 & 0.00 & 0.00 & 0.00 & 0.00 \\
\hline Total & $\begin{array}{l}100.00 \\
276958)\end{array}$ & $\begin{array}{c}100.00 \\
(258526)\end{array}$ & $\begin{array}{c}100.00 \\
(535484)\end{array}$ & $\begin{array}{c}100.00 \\
(386078)\end{array}$ & $\begin{array}{c}100.00 \\
(379727)\end{array}$ & $\begin{array}{c}100.00 \\
(765805)\end{array}$ \\
\hline
\end{tabular}

Source: Computed from Tables 1-1-8 to 3-1-8 of the same source of Table 3.1, Vol.II, pp.317-321. 
respectively. The possible reason for this may be the milltary law and war situation mentioned earlier. Nearly 40 percent of the migrants were below age 20. The number of migrants rises from the youngest age group to a maximum at ages $10-14$ followed by a general tendency to decline with age. This, however, does not mean that the largest volume of in-migration took place at ages 10-14, for the number in any particular age group includes not only migrants who were in that group at the time they entered Kabul city; but also survivors of earlier cohorts of younger migrants. The age at which maximum inmor-out-migration takes place may, however, be inferred from changes in the percentage of migrants in successive age groups in any normal population (Zacharia, 1968). Between any two consecutive 5 year age groups, the greatest increase is noted between ages $0-4$ and 5-9; and the greatest decrease between the ages 10-14 and 15-19. From this we may infer that the age group of maximum in-migration volume was close to 5 years and that of maximum out-migration volume around 15 years. But, this is an absurd situation. The corresponding figures, when computed and compared for Tehran city in 1976, it gives the years to be 15 and 35 as against Kabul city -5 and 15.

It is of importance here to note that children born to migrants are non-migrants. The very small proportion of children in 0-4 age group (Figure 3.4) shows perhaps a decline in family migration of young couples to the city during the four years prior to 1986. It is only to be expected as the city has lost its attraction as a metropolitan area where young people generally migrate mainly in search of job. In fact, Kabul's polltical situation and military law have been responsible for large scale out-migration. Notice that nearly 48 percent of non-migrants are low 10 years of age; whereas the corresponding proportion for migrants were only 14 percent. The differences observed in the age distribution of the 

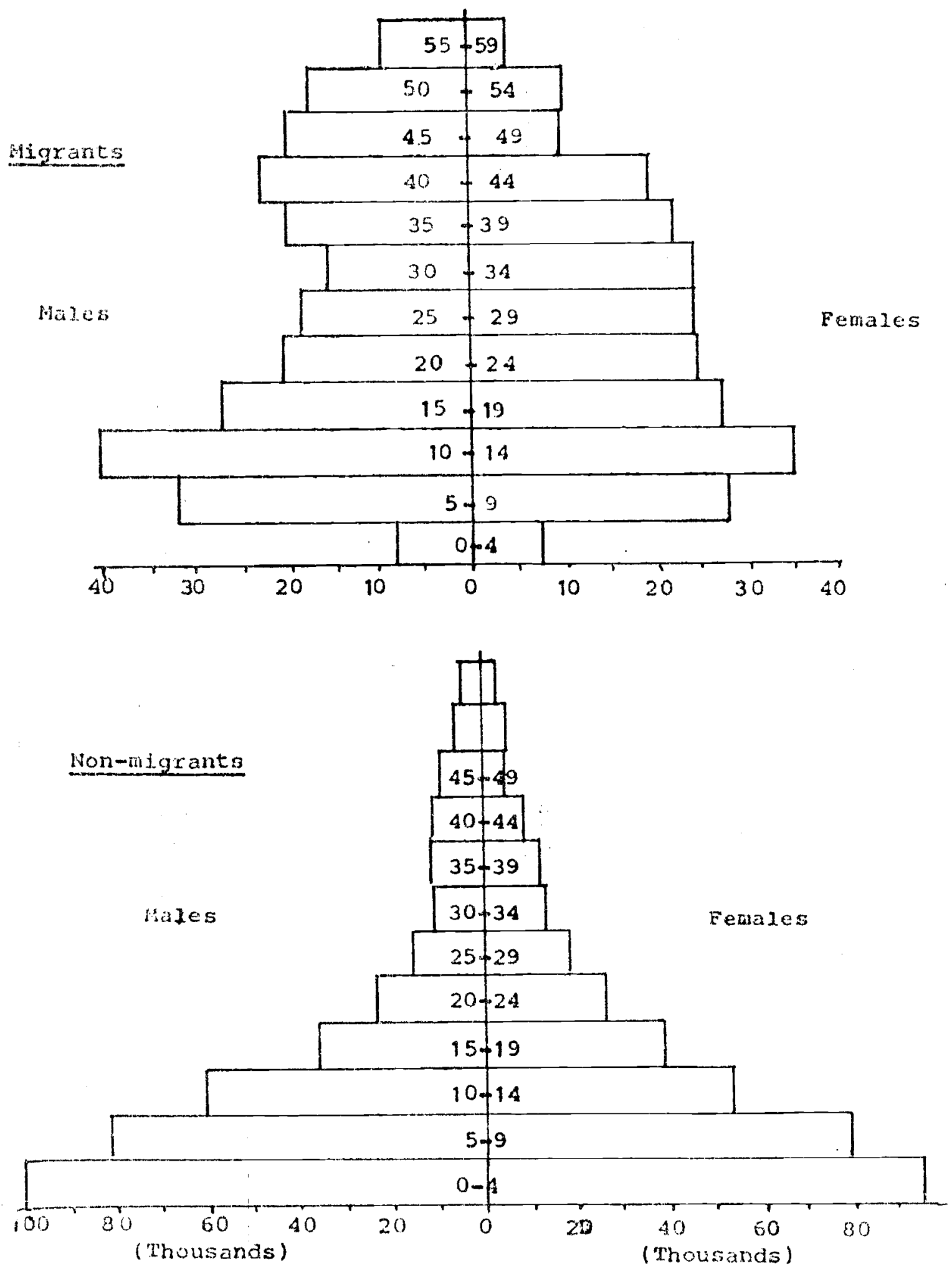

Figure 3.4 : Age pyramids of migrants and non-migrants in Kabul City, 193 i 
two groups arises because of the differences in their main source of growth. Births add population at the base of the pyramid as observed among non-migrants. The very broad base observed here includes children born in Kabul city among the migrants also.

A comparison of the male and female migrants shows that male migrants, on an average, are older than female migrants; the median age being 27.54 and 25.89 years respectively.

The proportion of female migrants in the age group 15-39 years was about 48 percent; while for males the proportion was only 36 percent. But the proportion of males above age 40 is much more than the corresponding proportion of females in each age group. Because more males in the 40 plus age group wigrate to the city for work or to join their family as the military law is not applicable to those aged 40 years and over.

\section{(11) Duration of Residence of the Migrants in Kabul City}

Duration of migrant's stay in Kabul city is an important factor in determining the shape of the age distribution at the time of enumeration. Other things being equal, the average age of migrant should bear a positive relation to duration of residence. The age distribution of migrants, in Kabul city, by duration of residence shows this tendency (see Table 3.22) for both males and females.

Table 3.22 Median age of migrants by duration of residence and sex, Kabul oity, 1986

\begin{tabular}{lccccc}
\hline & \multicolumn{5}{c}{ Duration of Residence } \\
\cline { 2 - 6 } & $0-1$ & $1-4$ & $5-7$ & $8-9$ & $10+$ \\
\hline Male & 15.14 & 17.63 & 21.22 & 25.03 & 40.57 \\
Female & 16.57 & 18.35 & 21.67 & 24.63 & 35.03 \\
Total & 15.93 & 18.01 & 21.47 & 24.58 & 37.39 \\
\hline
\end{tabular}

Source: Computed from Tables 1-1-8 to 3-1-8 of the same source of Table 3.1, Vol.II, $p p=319-321$. 
Usually the female migrants are younger in the urban centres of developing countries; but in Kabul city, the situation is reverso for those who have come to the city since 1979. The years from 1979 to 1986 being years of political disturbance, adult males were reluctant to come to the city. But the situation prior to 1979 shows an expected age pattern with males older than females.

\section{Sex Composition of Migrants}

The sex ratio of migrants and non-migrants by broad age group is given in Table 3.23 below. This table reveals the abnormality of sex

Table 3.23 Sex ratios of migrants and non-migrants by broad age groups, Kabul city 1986, Tehran olty 1976

\begin{tabular}{cccccc}
\hline & \multicolumn{2}{c}{ Migrants } & & \multicolumn{2}{c}{ Non-migrants } \\
\cline { 2 - 3 } \cline { 5 - 6 } & Kabul & Tehran & & Kabul & Tehran \\
\hline \multirow{2}{*}{$0-4$} & 105.53 & 104.5 & & 103.48 & 104.62 \\
$5-14$ & 115.09 & 113.62 & & 107.93 & 104.88 \\
$15-39$ & 81.17 & 122.72 & & 85.02 & 103.73 \\
$40-59$ & 140.87 & 127.71 & & 119.74 & 99.43 \\
$60+$ & 180.20 & 95.77 & 144.67 & 90.79 \\
\hline Total & 107.24 & 120.47 & 101.67 & 103.76 \\
\hline
\end{tabular}

Source: Far Kabul city, computed from Tables 1-1-8 and 3-1-8 of the same source of Table 3.1, Vol.II, pp.320-321.

For Tehran city, computed from Table 2, National Census of Population and Housing - 1976, Tehran Sharestan, Serial No.3,p.5.

ratios by age for both migrants and non-migrants in Kabul clty. Both of them have more or less the same pattern - the sex ratios for migrants and non-migrants increase upto age 15 then decrease in the age group 1539 and again increase at the higher ages. This is a pecullar situation observed in Kabul clty, perhaps, due to the out-migration of male agod 15-39 brought about by military law and return migration to the city 
after age 40. A comparison of the sex ratios of migrants and non-migrants in each age group with the corresponding figures of Tehran city also makes the abnormality of the sex ratio in Kabul clty abundantly clear.

The sex composition of migrants from different provinces shows (Table 3.24) that only migrants from 7 provinces, viz. Jouzjan, Foryab, Ghoor, Zaba l, Paktika, Badakhshan and Paktia had a sex ratio above 115;

Table 3.24 The sex ratio and the percentage distribution of migrants by province of birth, Kabul city,1986

\begin{tabular}{lcclcc}
\hline $\begin{array}{c}\text { Province of } \\
\text { birth }\end{array}$ & Sex ratio & $\begin{array}{c}\text { Percentage } \\
\text { of } \\
\text { migrants }\end{array}$ & $\begin{array}{c}\text { Province of } \\
\text { birth }\end{array}$ & Sex ratio Percentage \\
of \\
migrants
\end{tabular}

Source: Computed from Tables $2-1-6$ and $3-1-6$ of the same source of Table 3.1, Vol.II, pp.305-306.

but their contribution to the total migrants was very small. The migrants who entered Kabul city at different periods of time had quite different sex ratios, but followed the same pattern by 


$$
-: 63:-
$$

age - all of them have low sex ratios in the age group 15-39 (Table 3.25), indicating that even among migrants of longer duration 15-39 age group have generally lower number of males than females for reasons already mentioned.

Table 3.25 Sex-ratios of migrants by age and by duration of residence, Kabul city, 1986

\begin{tabular}{|c|c|c|c|c|c|}
\hline \multirow{2}{*}{$\begin{array}{l}\text { Age } \\
\text { Group }\end{array}$} & \multicolumn{5}{|c|}{ Duration of Residence } \\
\hline & $0-1$ & $1-4$ & $5-7$ & $8-9$ & $10+$ \\
\hline $0-4$ & 105.23 & 105.72 & 0 & 0 & 0 \\
\hline $5-14$ & 117.59 & 115.97 & 113.11 & 112.28 & 121.67 \\
\hline 15-39 & 74.80 & 79.62 & 86.32 & 88.14 & 77.50 \\
\hline $40-59$ & 156.33 & 149.00 & 133.66 & 140.91 & 139.37 \\
\hline $60+$ & 183.89 & 210.71 & 164.56 & 145.83 & 184.97 \\
\hline Total & 107.38 & 108.29 & 105.94 & 105.88 & 107.63 \\
\hline
\end{tabular}

\section{d. Educational Attainment of Migrants and Non-migrants}

Compared with non-migrants, migrants have a higher percentage of illiterate persons. As it can be seen from Table 3.26, more than 55 percent of the migrants were 1111 terate and the corresponding figure for non-migrants was only 35 percent. The same is true for males and females separately.

The migrant-non-migrant differentials are quite high particularly among females. It may be the outcome of the higher differeno tial of the female educational facilities between Kabul oity and the rest of the country. This is supplemented by cultural feelings which are comparatively more favourable to female education in Kabul city. 


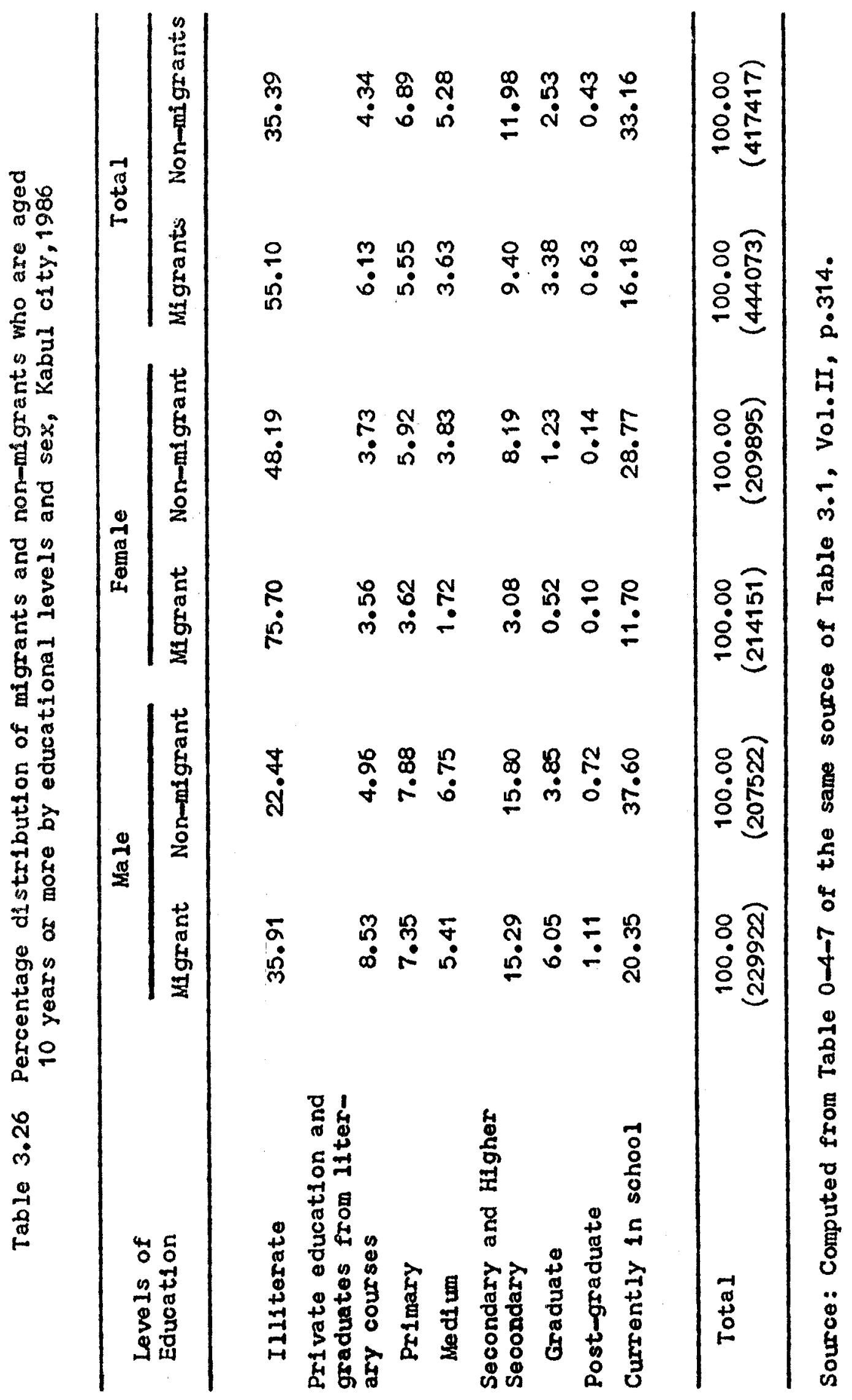




\subsection{SUMMARY}

Kabul clty has a rapldly growing population and in 1986 its population was $1,301,289$. This population is distributed among the eleven districts within the city. The overall density of the population was 6,109 persons per sq.Km. in 1986. The overall sex ratio of the city was 103.9; but, an abnormally low sex ratio was observed for the 15-39 age group, i.e., 83 males per 100 females.

Nearly half the population of the city was in the 0-14 age group, making it an young population. Nearly 45 percent of the population belonged to never married category and that goes well with the age composition. Widowhood claimed only a small share; but the divorcees were almost negligible.

The average household size was very high in the city -6.62 persons. Nearly two-thirds of the households had 6 persons or more. The effective literacy rate was comparatively low. It was 64.3 percent for males and 36.4 percent for females. Minority nationalities had a higher literacy rate than others. About 26 percent of the population aged 5 years and above have enrolled in school. Highly educated persons (Graduate and above) formed only a very small proportion $(6.43 \%)$ of the literate population.

The estimated crude birth rate of the city wast $\sqrt[n e a r l y]{49}$ and the total fertility rate was 6 . Social surveys done in the city revealed a crude death rate of about 20 and infant mortality rate of 101 . Of the 1986 population of the city, 40 percent were migrants and twofifths of them had come from Parwan and Kabul provinces. Atleast one migrant was found in 69 percent of the total househords of the city. Of the one person households, more than four-fifths were migrant households. Migrants were more illiterate than non-migrants. 


\section{CHAPTER IV}

\section{LEVEL OF LABOUR FORGE PARTICIPATION AND OTHER RELATED FINDINGS}




\subsection{IETRODUCTION}

fruman resources are a critical factor in economic developinent and one can ill-afford to let them remain unutilized or underutilized or nalutilized. The basic reason why many present developing societies are being plagued by pressing problems like poverty, unemployment, litulnutrition, illiteracy and squalor is precisely due to the poor upgrading and iuproper utilization of human resources (Sabhanayakatn, 1988). Ai assesment of the existing stcck of the economically active population in a disaggregated form is the primary requirement for the proper development and utilization of human resources available in Kabul city. This chapter is an attempt in this direction.

\subsection{ACTIVITY RATES}

The economic activity information is collected only for those who are 10 year of age and above in the Kabul city census. Accordingly, when the activity rate was calculated, it worked out to be 65 percent for males and 8 percent for females.

In Kabul city the crude activity rate has registered a decline over the 21 years period between 1965 to 1986 . It fell from 27.4 to 24.4. This decline was mainly due to a decline in male activity rate from 46.5 to 42.8 . During this period female activity rate has registered an increase from 3.03 to 5.35. This increase may be due to the out migration of adult males and consequent need for some women to earn extra money and/or the preference shown by some employers for female workers as they are comparitively cheap. The general activity rate is very much the same as that of 1976 Tehran city where the rate was 65 percent for males and 10 percent for females. 
The wide male female differential in work participation rate, as can be seen from table 4.1 , is common for all districts.

Table 4.1 : Economic Activity Rates by Districts Kabul City, 1986

\begin{tabular}{|c|c|c|c|c|c|c|}
\hline \multirow[b]{2}{*}{ District } & \multicolumn{3}{|c|}{ Crude* } & \multicolumn{3}{|c|}{ Refined* * } \\
\hline & Male & Female & Total & Male & Female & Iota므. \\
\hline First & 53.55 & 5.22 & 31.72 & 76.38 & 7.84 & 46.29 \\
\hline second & 45.08 & 6.03 & 26.05 & 65.48 & 8.70 & 37.69 \\
\hline Third & 42.09 & 8.21 & $25 \cdot 23$ & 61.15 & 11.17 & 36.36 \\
\hline Eourth & 43.11 & 6.96 & 25.24 & 63.99 & 10.18 & 37.19 \\
\hline Fifth & 40.03 & 3.21 & 22.09 & 62.03 & 4.96 & 34.22 \\
\hline sixth & 43.41 & 3.24 & 23.85 & 67.00 & 5.02 & 36.89 \\
\hline Seventh & 42.69 & 4.30 & 23.90 & 64.72 & 6.57 & 36.36 \\
\hline Eighth & 40.73 & 5.88 & 23.44 & 62.06 & 8.77 & 35.34 \\
\hline Nineth & 42.00 & 5.84 & 25.22 & 66.50 & 9.16 & 38.16 \\
\hline Tenth & 43.47 & 6.64 & 25.21 & 65.08 & 9.44 & 37.33 \\
\hline Eleventh & 40.15 & 5.48 & 22.79 & 61.90 & 8.22 & 34.65 \\
\hline Total & 42.79 & 5.35 & 24.43 & 64.86 & 8.05 & 36.90 \\
\hline
\end{tabular}

* Economically active population per 100 total population.

* Economically active population per 100 population aged 10 years and above.

Source: Computed from the same source of table $3.1 \mathrm{pp} .56,71,87,103,119$, $135,152,169,185,201,217$ and Vol.II,pp.268-270 and 329-331.

This difference was found to be maximum for the first district and minimun for the third district. Female work participation rate is highest in thixd district where some industries preferred to employ wonien to save on labour cost. Moreover the females of the third district had the highest literacy rate and the lowest level of fertility among all districts which enable them to enter labour force. 
4.3. AGE-SEX SPECIEIC ACTIVITY RATES

Activity rate of persons belonging to different age groups are found to differ all over the world. The activity rate of prine age males (25-49) are found to be above 90 percent, whereas the activity rate at the extremes of the working life span will be low for the youngsters who will only be entering the labour force while the elderly will be retiring. But these two process will differ according to the level of development of the economy and in less developed countries these rates are found to be comparitively high because of the need to participate due to poverty and the availability of opportunity to job. In an urban setup opportunity will be more in the informal sector.

Female participation is more the result of cultural and social norms and financial need. Thus no generalization can be made about their participation. Generally their activity rate will be rach below that of males.

Age-sex specific activity rates given in táble 4.2 and figure 4.1 bring out very clearly male-female differential in economic activity rate for both Kabul city and Tehran city. Interestingly the maximum female activity rate for both the cities was found in the same age group (25-29) which touched the same level 19 percent. For males the curve indicate a central plateau pattern where the adjucent age groups from 30-49 of Kabul city and from 30-44 of Tehran city are having more or less the same rates (around 96 percent and 97 percent respectively).

The participation in economic activity by female children is low in Kabul city and in Tehran city while that of older women is almost negligible for Kabul city and noticeable proportion of them in Tehran 


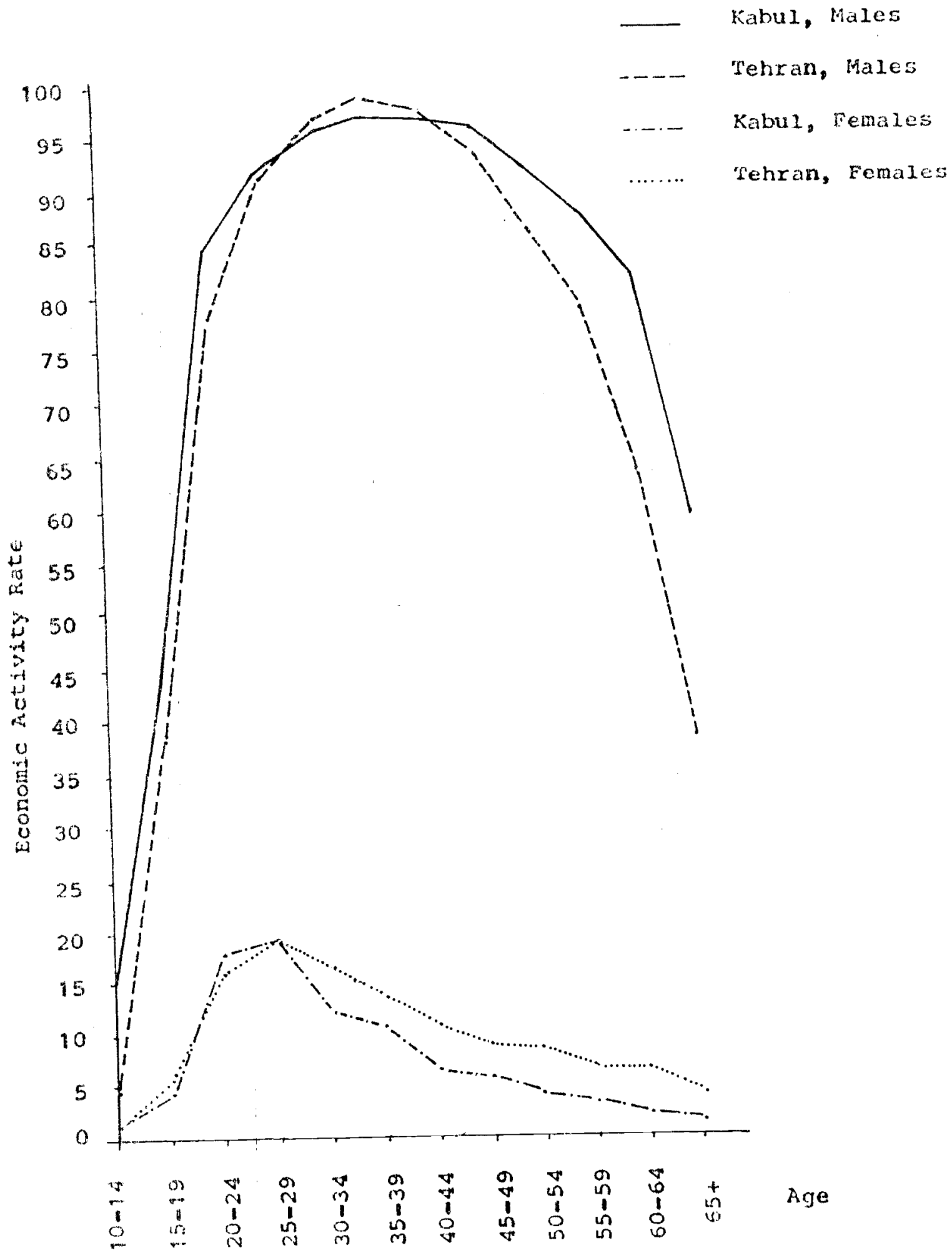

1igure 1.1: rge-Sex Specific Activity Rates, Kabul City, 1986 Tehran city, 1976. 
dity were working.

The pattern of sex-age specific activity rates is found to be in tune with expectation.

Table 4.2 : Sex-age Specific Activity Rates, Kabul City -1986, Tehran City - 1976.

\begin{tabular}{ccccc} 
Age & \multicolumn{1}{c}{ Kabul city $(1986)$} & \multicolumn{1}{c}{ Tehran City $(1976)$} \\
\cline { 2 - 4 } $10-14$ & 13.26 & 1.03 & 4.75 & 1.04 \\
$15-19$ & 43.88 & 4.52 & 37.89 & 5.13 \\
$20-24$ & 84.08 & 17.84 & 77.47 & 16.83 \\
$25-29$ & 91.52 & 18.96 & 90.91 & 18.97 \\
$30-34$ & 95.61 & 12.27 & 96.31 & 16.39 \\
$35-39$ & 97.08 & 10.32 & 98.07 & 13.18 \\
$40-44$ & 96.69 & 6.30 & 97.18 & 10.62 \\
$45-49$ & 95.71 & 5.58 & 93.77 & 8.66 \\
$50-54$ & 92.17 & 3.65 & 86.84 & 7.84 \\
$55-59$ & 87.13 & 2.91 & 77.71 & 6.20 \\
$60-64$ & 81.71 & 2.17 & 63.07 & 6.12 \\
$65+$ & 58.20 & 1.66 & 38.49 & 4.12 \\
\hline Tot & 64.86 & 8.05 & 65.23 & 9.86 \\
\hline
\end{tabular}

Source: 1) Computed from tables $02-1-10$ and $03-1-10$ of the same source of table $3 \cdot 1$, Vol.II pp.330-331.

2) Computed from table 16 of National Census of Population and Housing 1976, Tehran Sharestan Serial No.3,p.190.

4.4. MARITAL STATUS SPECIFIC FEMRLE ACTIVITY RATES BY AGE

Activity rate by marital status is given only for females for the data are available only for them. But it is not a matter of concern as male participation generaliy will not very much on the basis of marital status (United Nations, 1989). 
The Kabul city's situation patterns of participation in economic activity by women of different marital status groups is shown in table 4.3 and figure 4.2. The lowest level is for currently

Table 4.3: Marital Status specific Activity Rates by Age, Female Population, Kabul City, 1986.

\begin{tabular}{|c|c|c|c|c|c|}
\hline Age & $\begin{array}{l}\text { Never } \\
\text { Married }\end{array}$ & $\begin{array}{c}\text { Currentiy } \\
\text { Married }\end{array}$ & Widowed & Divorced & Unspecified \\
\hline $10-14$ & 0.99 & 3.94 & 23.33 & 28.57 & 2.73 \\
\hline $15-19$ & 4.82 & 3.28 & 7.69 & 33.33 & 0.00 \\
\hline $20-24$ & 29.78 & 11.28 & 14.60 & 41.67 & 7.14 \\
\hline $25-29$ & 47.09 & 14.82 & 20.73 & 38.10 & 25.00 \\
\hline $30-34$ & 38.38 & 10.28 & 24.72 & 37.93 & 0.00 \\
\hline $35-39$ & 30.50 & 8.74 & 25.64 & 61.90 & 40.00 \\
\hline $40-44$ & 20.07 & 4.77 & $17 \cdot 64$ & 42.11 & 33.33 \\
\hline $45-49$ & 15.79 & 4.03 & 13.75 & 27.27 & 0.00 \\
\hline $50-54$ & 9.20 & 2.26 & 7.56 & 23.81 & 20.00 \\
\hline $55-59$ & 8.46 & $2 \cdot 18$ & 4.37 & 16.67 & 0.00 \\
\hline $60-64$ & 4.26 & 1.70 & 2.61 & 16.67 & 0.00 \\
\hline $65+$ & 3.85 & 1.80 & 1.45 & 13.33 & 10.00 \\
\hline Total & $\begin{array}{c}7.39 \\
(12535)\end{array}$ & $\begin{array}{l}8.32 \\
(18502)\end{array}$ & $\begin{array}{c}9.57 \\
(3024)\end{array}$ & $\begin{array}{l}35.45 \\
(189)\end{array}$ & $\begin{array}{l}5.58 \\
(11)\end{array}$ \\
\hline
\end{tabular}

Source: Computed from tables 1-2-10 to 6-2-10 of the same source of table $3 \cdot 1$, vol.II pp.332-337.

married women. In general their financial protection is guarantied by their husbands thereby reducing the need for labour force participation. The never married group shows a steep increase in labour force participation: rate reaching the maximum in the 25-29 age group following with is a continous decrease. The same pattern is observed for widows (excluding the very yound age group), but the 


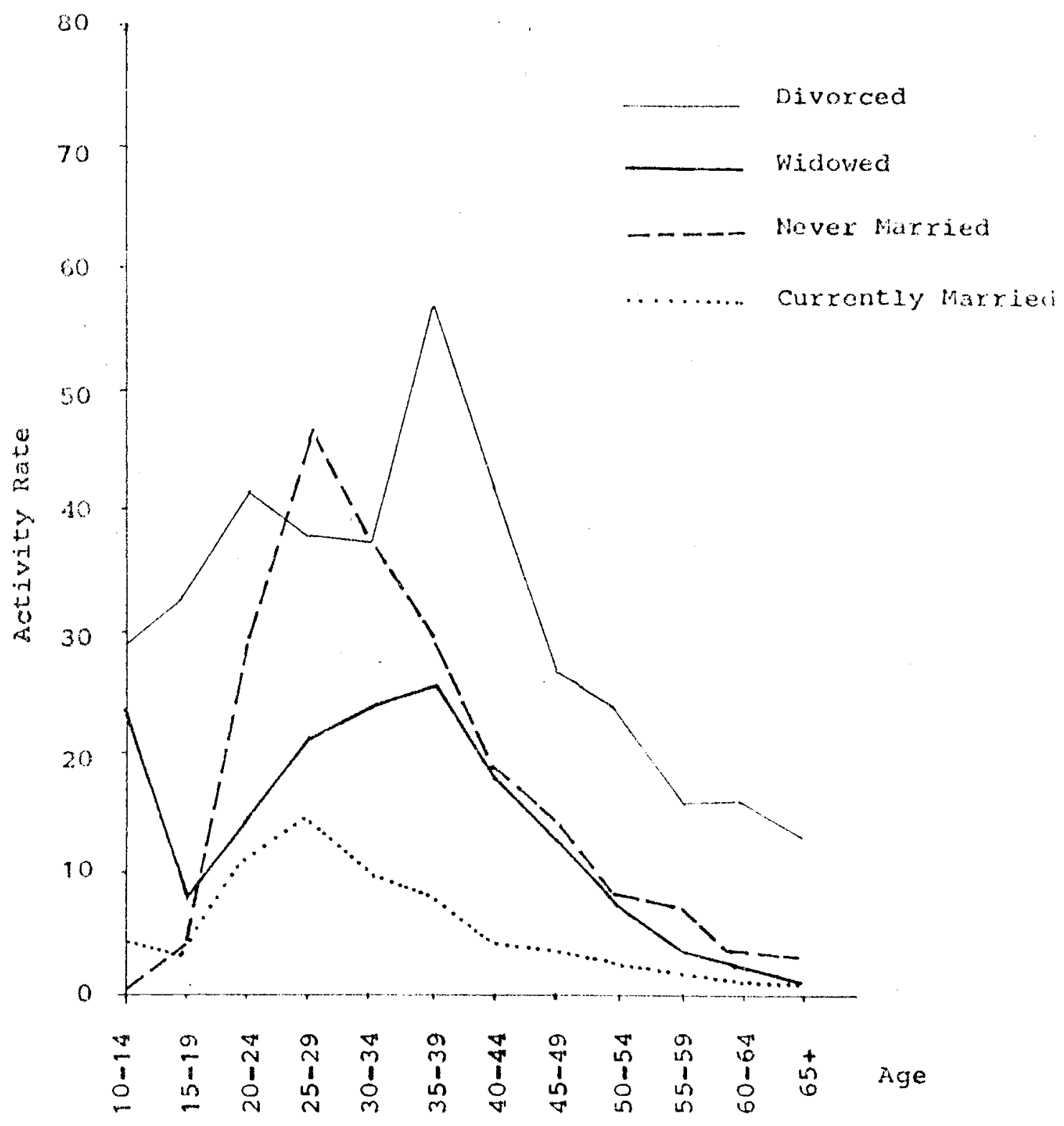

Fitue 4.2: Marital status specific Female Activity Rates by Age, Kabul City, 1986. 
rates were much lower than that of never married group and the maximum participation was reached in the 35-39 age group. The highest level of participation was observed among the divorced reflecting the cultural situation. The society disapproves of divorce and even her own parents would not be willing to support her. In other words for them: self-supporting becomes indispensible. 4.5. EDUCATION SPECIFIC ACTIVITY RATES

Education plays a major role in labour force participation depending upon the structure of the economy. In an urban set up where non-agricultural activities predominantes the role of education is of special interest. An increase in enrolment means less children will be available for work and better jobs for them later (United Nations, 1968 ).

As it is shown in table 4.4 the high activity rates of Kabul city population was observed in high levels of education. Table 4.4 : Education Specific Activity Rates, Kabul City, 1986

\begin{tabular}{lrrr}
\hline Completed level of education & \multicolumn{3}{c}{ Activity Rate } \\
\cline { 2 - 4 } Illiterate & 81.96 & 2.22 & 28.46 \\
Private education & 85.71 & 6.19 & 58.92 \\
Literacy course & 93.22 & 19.53 & 64.25 \\
Primary & 91.64 & 7.85 & 59.98 \\
Medium & 93.08 & 20.80 & 70.87 \\
Secondary & 93.39 & 70.50 & 87.78 \\
Higher secondary & 92.13 & 91.32 & 91.85 \\
Graduate & 90.67 & 88.46 & 90.35 \\
Post-graduate & 91.59 & 88.82 & 91.28 \\
Curgentiy in school & 6.29 & 1.39 & 4.30
\end{tabular}

Source: Computed from tables 1-2-4- to 3-2-4, and 1-2-12 to 3-2-12 of the same source of table $3 \cdot 1$, Vol.II pp.295-297 and 356-358. 
The highest activity rate by female workers was found to be in higher secondary level of education, followed by post-graduate and graduate. Women with some secondary schooling hold third position in this order. Females with low levels of education had generally the lowest activity rate. While the activity rate of male workers were high in each level of education, the highest rate for them was found in secondary level of education. All male workers with some completed level of education had an activity rate of more than 90 , except the category of"private education" where it was nearly 86 percent. The high activity rates of male and female workers in the category of "Literacy courses" is mainly because these courses are especially for illiterate workers, the majority of whom are already employed.

\subsection{ECONOMIC DEPENDENCY RATIO}

Economic dependency ratio which is a measure of actual economic burden of the labour force is given in table 4.5. It shows a very high dependency ratio and it has increased during 1965-86 period. This ratio which was 109.3 for males, 156.1 for females and 265.4 for total population of Greater Kabul in 1965 increased respectively to $133.7,175.7$ and 309.4 in 1986. Two possible reason can be given for this. one is the increase in the number of students whose share in economically inactive population increased from 23 percent in 1965 to 37 percent in 1986, and the other is the effect of war in the country which made a part of the working population in the age group 15-39 to leave the city. The high dependency ratio of Kabul city can be also seen by comparing it with that of Tehran city. The economic dependency ratio in Tehran city works out to be 101.73 for males, 126.24 for femaleis 
Table 4.5 : Economic Dependency Ratio by Sex and Districts, Kabul City, 1986

\begin{tabular}{|c|c|c|c|c|c|}
\hline District & & lle & Female & Tot & :al \\
\hline First District & 80.30 & $(28.62)$ & $134.94(87.36)$ & $215 \cdot 24$ & $(115.99)$ \\
\hline Second District & 108.06 & $(46.77)$ & $175.81(118.55)$ & 283.87 & $(165.32)$ \\
\hline Third District & $115 \cdot 28$ & $(53.24)$ & $181.02(121.76)$ & 296.30 & $(175.00)$ \\
\hline Fourth District & 113.99 & $(48.60)$ & $182.17(120.28)$ & 296.15 & $(168.88)$ \\
\hline Fifth District & 139.22 & $(56.89)$ & $213.42(134.28)$ & 352.65 & $(192.22)$ \\
\hline Sixth District & 121.76 & $(46.01)$ & $197.52(125.07)$ & 319.28 & $(171.07)$ \\
\hline Seventh District & 122.44 & $(49.72)$ & $196.02(125.28)$ & 318.47 & $(175.00)$ \\
\hline Eighth District & $127 \cdot 38$ & $(53.53)$ & $199.17(129.46)$ & 326.55 & $(182.99)$ \\
\hline Nineth District & 121.69 & $(44.41)$ & $191.19(117.63)$ & 312.88 & $(162.03)$ \\
\hline Tenth District & 113.06 & $(46.64)$ & $183.58(121.27)$ & 296.64 & $(167.91)$ \\
\hline Eleventh District & 131.12 & $(54.15)$ & $207.68(134.44)$ & 338.80 & $(188.59)$ \\
\hline Total & 133.68 & $(54 \cdot 18)$ & $175.70 \quad(85.38)$ & 309.38 & $(139.56)$ \\
\hline
\end{tabular}

Note: Figures in brackets are calculated excluding children less than 10 years of age. Source: Some as Table 4.1

and 238.40 for total population in 1976.

As one would expect, the female dependency ratio was much higher than that of males in all districts (see table 4.5).

The majority of districts had a dependency ratio more than 312 , indicating a very heavy burden on economically active population. While this burden is heavier on the workers of the fifth district (353), the vorkers of the first district, comparatively have small number of dependents $(215)$.

4.7 GROSS YEARS OF ACTIVE LIFE

Gross years of active life shows the average number of years a person would spend in active life during a given working life span, if 
that person follows a given age-specific activity rate schedule. For Kabul city gross years of active ilfe was calculated for males using 1986 age-specific activity rates schedule and defining the working life span to be 55 years from 10 to 64 . The results shows (table 4.6 ) that each male spends about 44 years in active life or 80 percent of their working life span in active participation. If the 15-19 age Table 4.6: Gross years of active life for males in aged 10 years and over and 10 to 65 years, Kabul city, 1986.

\begin{tabular}{|c|c|c|c|}
\hline $\begin{array}{l}\text { Age Interval } \\
\text { (exact ages) }\end{array}$ & $\begin{array}{l}\text { Number of years in } \\
\text { age interval }\end{array}$ & $\begin{array}{l}\text { Specific } \\
\text { activity rate }\end{array}$ & $\begin{array}{l}\text { Average number } \\
\text { of active years } \\
\text { in age interval. }\end{array}$ \\
\hline-11$)$ & $\ldots$ & $(3)$ & $(4)=(3) \times(2)$ \\
\hline $10-14$ & 5 & 13.26 & 0.663 \\
\hline $15-19$ & 5 & 43.88 & 2.194 \\
\hline $20-24$ & 5 & 84.08 & 4.204 \\
\hline $25-29$ & 5 & 91.52 & 4.576 \\
\hline $30-34$ & 5 & 95.61 & 4.781 \\
\hline $35-39$ & 5 & 97.08 & 4.854 \\
\hline $40-44$ & 5 & 96.69 & 4.835 \\
\hline $45-49$ & 5 & 95.71 & 4.786 \\
\hline $50-54$ & 5 & 92.17 & 4.609 \\
\hline $55-59$ & 5 & 87.13 & 4.357 \\
\hline $60-64$ & 5 & 81.71 & 4.086 \\
\hline $65-90$ & 25 & 58.20 & 14.55 \\
\hline rotal $(10-65)$ & 55 & & 43.945 \\
\hline rotal $(10-90)$ & 80 & & 58.495 \\
\hline
\end{tabular}

Source: The figures of column 3 is taken from table 4.2 .

group is excluded from the computation reducing the working life span to 45 years, gross years of active life was found to be 41 years 1918 of the working life span). This is true for almost all countries far 
males, whether developed or developing. This is in tune with what prevails in the capital cities of many other developing countries. For example the gross years of active life of Tehran male population in 1976 was 41.20 years in the age range of 10 to 65 and 50.82 years in the age range of 10 to 90 . But for the 10-90 age group, between Kabul and Tehran the difference is noticeable 1.e. 58.5 years for Kabul (738 of the working life span of $10-90$ years) and 50.8 years for Tehran (63.58). This shows a comparitively higher level of oldage work participation in Kabul compared to Tehran.

For females, the gross years of active life when worked out separately gives 4.3 years for $10-64$ years and 4.1 years when the working life span was truncated at the extremes i.e. for 15-19 age group.

\subsection{WORKING IIFE TABLE}

An abridged working life table for males in Kabul clty is constructed using age-specific labour force participation rate of 1986 census. This is a current working life table and is sufficient to help those who are concerned with labour market dynamics in deciding the job prospects and replacement needs. Though central statistics office of Afghanistan collected information about mortality during the last 12 month prior this census, neither was it published, nor was it given for use here even after repeated requests. The most probable reason for this may be that the death rate is either very high or there is no improvement in the mortality levels compared to the 1979 situation. Therefore the $\left(l_{x}\right)$ function is taken from abridged life table for male population of urban Afghanistan, 1979 (Rumzi, 1985), 
under the assumption that there is no improvement in mortality levels during 1979-86. The rationality of this assumption lies in the fact that the war in the country has practically increased the death rate for the country as a whole.

In Kabul city the war may not have lead to an increase in death rate because of the comparatively higher concentration of health facilities, but the wax may not have allowed an improvement in the mortality situation. Further, this $I_{x}$ (of urban Afghan population) is applied for Kabul, as almost half of the total urban population was living in this city.

According to table 4.7 out of a group of $1,00,000$ male babies born alive 78,156 were alive at the age of 10 , the age at which labour force participation starts. At age 65 the number of alive were 40,975 of which 23,847 were in the labour force.

The labour force curve show in Figure 4.3 shows maximum partio cipation between 25-34 years and it closely follows the population till mid 40s. A sharp fall in labour force participation takes place after age 50.

\section{8 .1 Length of Working Life}

The table ( $t$ able 4.7) shows that a person aged 15 years in 1986 could expect to be in labour force for 39 years (column 11). Two important things to be noted here is that, it is an average period of time and that it applies only to men of a given age in the labour force. At the other extreme a man of 65 years could expect 6.69 years of active 1ife. Column 12 gives the average inactive years - this is the difference between expectation of 1 ife and expectation of working life. From age 30 onwards the number of inactive years shows to be more or less the 


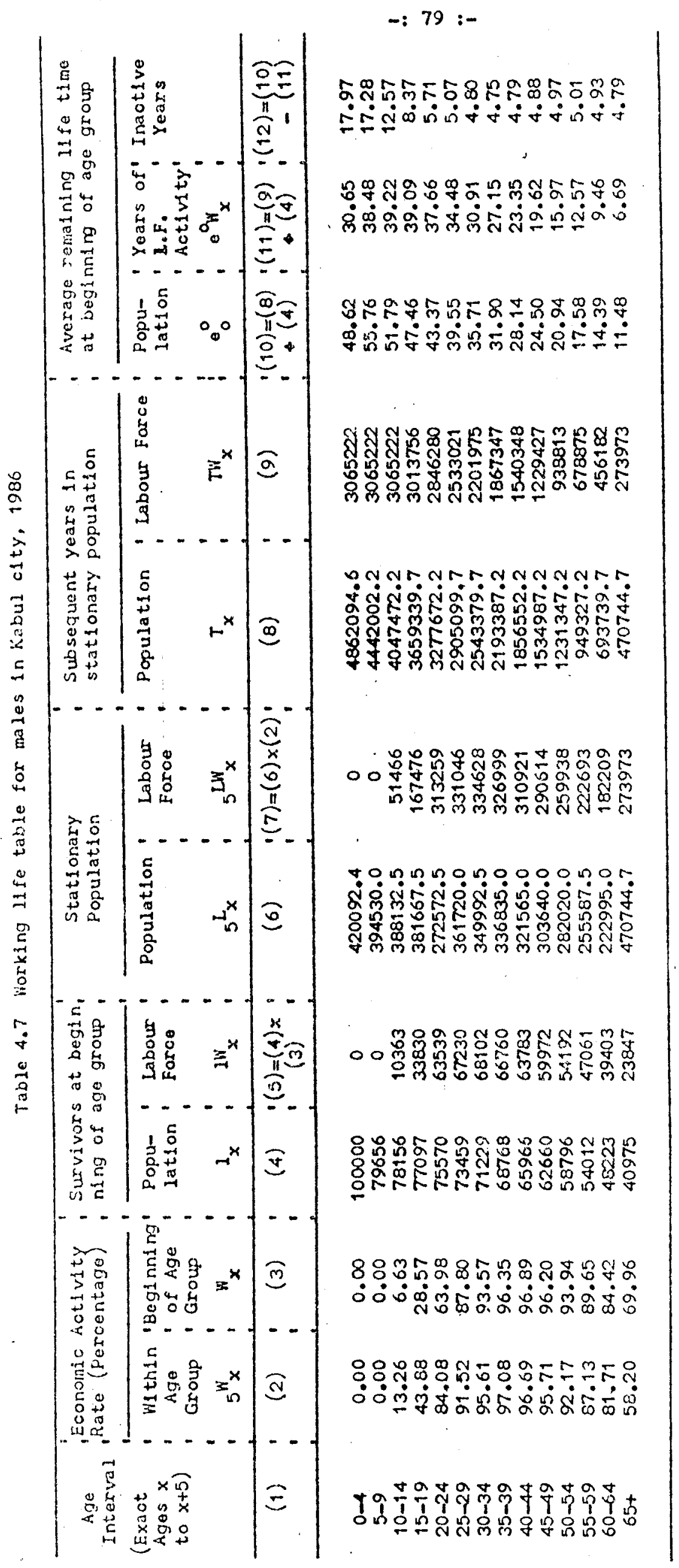




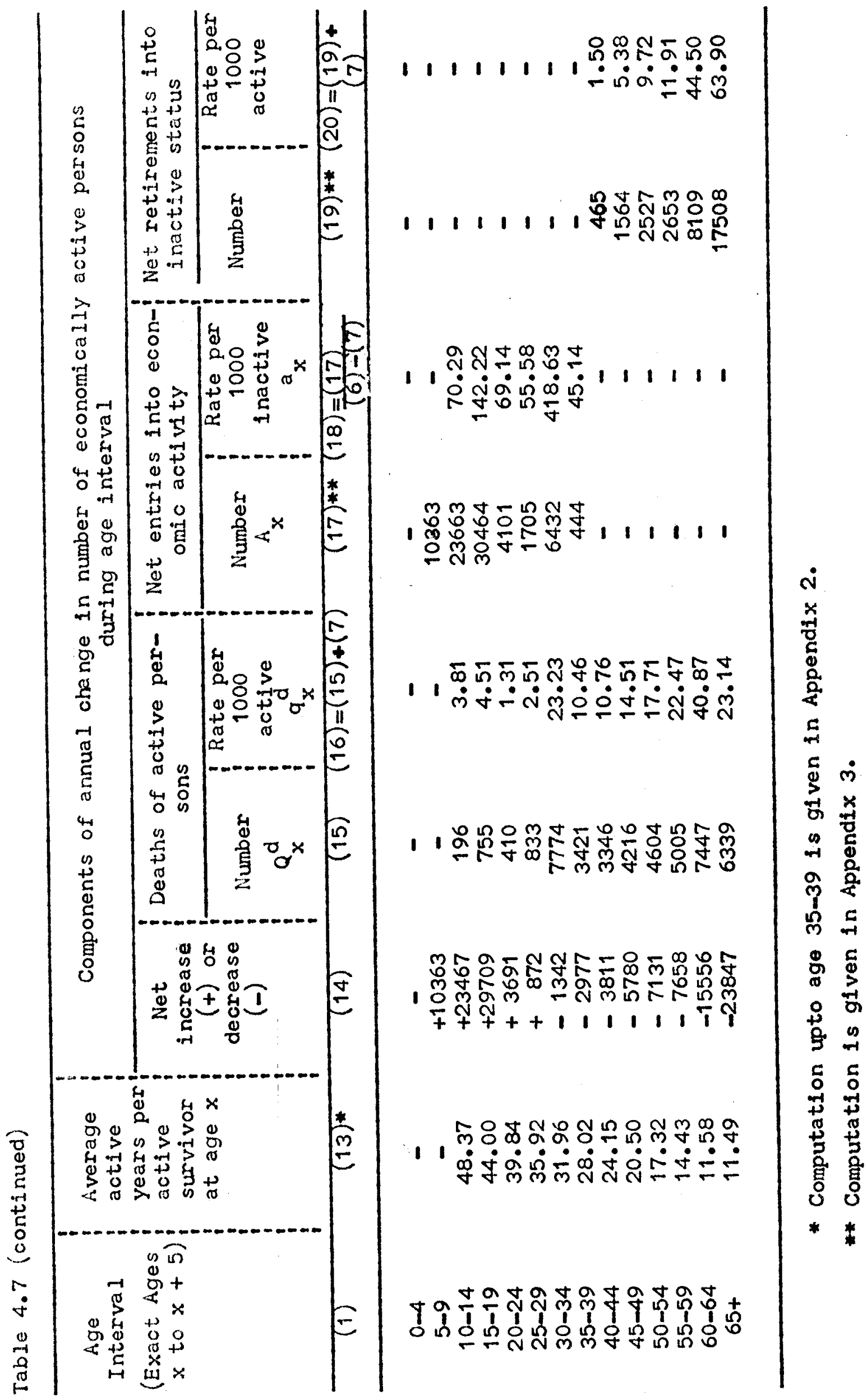




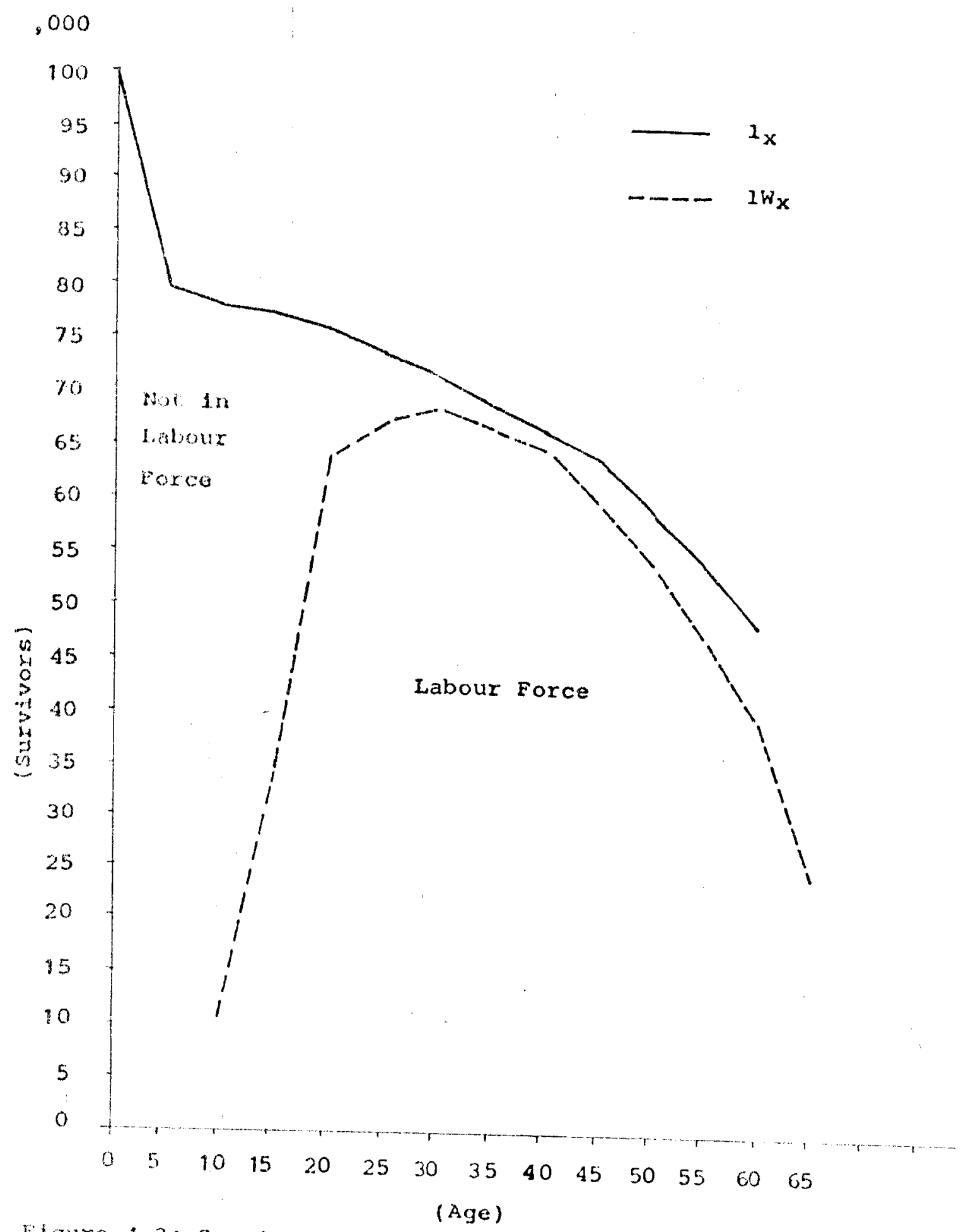

Figure 4.3: Survivors of 100,000 males born alive, Kabul City, 1986. 
sabio for subsequent years as well.

on the average the length of economically active years to be lived by male Kabul inhäbitants was 30.65 years. With $e_{0}^{0}=48.62$ they had 17.97 years of inactive life.

\section{8 .2 Loss of active years by mortality}

This is the difference between the gross years of active life and the expectation of active life either at birth or at the age of entry into labour force (taken as age 10).

\footnotetext{
Active Age Groups $10-64 \quad 10-90$

1. Gross years of active iffe $43.95 \quad 58.50$

2. Expectation of active life at birth $27.91 \quad 30.65$

3. Expectation of active iffe at age 10 $35.71 \quad 39.22$

4. Loss of active life by mortality at

i) birth $(1-2)$

16.04 27.85

ii) at age $10(1-3)$ 8.24 19.28

It shows that out of a population maximum years of 55 years assumed in this study $(10-64)$ the male gross years of active life was found to be nearly 44 years. But the expectation of active life at age 10 was nearly 36 year giving a loss of 8 years by mortality. similarly if the maximum period is increased to 80 years the loss will be 19 years.
}

\section{8 .3 Loss of active years by retirement}

Column 19 of table 4.7 shows the absolute numbers of Kabul city males leaving labour force due to retirement and column 20 express 
these numbers as specific rates per 1000 active males. The separation rates by age due to retirement are fairly stable and low (less than 12 per 1000) until age 60, thereafter the rates increase rapidly to 44.5 per 1000 male workers aged $60-64$ and 63.90 per 1000 among males of aged 65 years and above. This is an expected pattern seen in all othex countries either developed or developing. Further it is found that half of Kabul city economically active population retired after 65 year of age (median age of retirement: 65.35 years).

\subsubsection{Labour force accession (entry)}

This is a key factor in labour market dynamics, as labour force is directly affected by the magnitude of labour force accessions that take place each year. column 17 of table $\$ .7$ shows that absolute numbers of males entering into labour force of Kabul city for the first time at various ages from the stationary (inactive) population in 1986 and column 18 of this table express these numbers as specific rates per 1000 males in the stationary inactive population. Accordingly about 84 percent enter the labour force when theywere below 20 years of age and nearly 40 percent of them in 15-19 age group. The annual rate of entry which usually reaches its maximum, in younger ages $(10-24)$ in less developed countries, however its first peak was found to be in 15-19 age group, a very high rate of entry was observed in 30-34 age group showing abnormal situation resulting from a drastic abnormal decrease in the number of labour force between age groups 30-34 and 35-39 (see column 5 of table $4.7)$.

Further it is found that half of the Kabul city labour force entered before they were 16 years - the median age of entry worked out to be 15.75 years. 


\subsubsection{Replacement rate and Replacement ratio}

The rate of replacement of the labour force (the difference between the annual crudd rate of entries and the sum of the crude rates of retirements and losses by death) was found to be 24.1 per 1000 male population of Kabul city. The components per 1000 were: entries: 43.5 , retirement:7.2 and loss by death:12.2. These components (annual crude rates per 1000 of the labour force) are obtained from the totals at the foot of the appendix 4, as explained in methodology.

The labour force replacement ratio, the number of entries into the labour force for 100 of the total losses (death and retirements), for Kabul city was found to be 225 .

4.9. SUMHARY

In Kabul city the crudd activity rate has registered a decilne over the 21 years period between 1965 and 1986, mainly due to a decline in male activity rate. However the female activity rate has shom an increase. The wide male-female differential in work participation is cominon for all districts. This difference was found to be maximua for the first district and minimum in the third district, where the female work participation rate also was found to be high.

The maximum female activity rate (198) was found to be in the 25-29 age group. For males the rates indicate a central plateau pattern where the adjucent age groups from 30 to 49 were having mort or less the same rates of around 96 percent. The participation in economic activity by female children and older women were almost negligible. 
The examination of marital status specific female activity rate by age shows the lovest level for currently married women, as their financial protection is guarantied by their husbands. The Level of work participation of widowed was higher than currently warried women but lower (except the very yound age group) than never warried. But among females the highest level of participation was found for divorced women reflecting the cultural situation.

Activity rates were higher among educated persons.

The economic dependency ratio was very high in Kabul city. As one would expect the female dependency ratio was much higher than that of males in all districts. The majority of districts had a dependency ratio of more than 312 indicating a very high burden on economically active population.

The gross years of active life of Kabul city male population was found to be 44 years constituting 80 percent of their working life span. For females the gross years of active life when worked out separately gives 4.3 years for $10-64$ years and 4.1 years for $15-59$ years of working life span.

On the average the length of economically active years to be lived by male inhabitants of Kabul city in 1986 was 30.65 years. With $e_{0}^{\circ}=43.62$ they had 17.97 years of inactive 1ife. The loss of active life by thortality was found to be 8 years.

The retirement rate was found to be fairly stable and low (1ess than 12 per 1000 ) until age 60 , but their-after the rates increased rapidy. Further it was found that half of Kabul city econouically active population retired after 65 years of age - median age 
of retirement being 65.31 years.

It was observed that 84 percent of the population entered the labour force when they were below 20 years of age and the median age of entry was found to be 15.75 years.

The annual crude rates of entry, retirement and loss by death per 1000 of the labour force worked out to be $43.5,7.2$ and 12.2 res.o pectively, giving a replacement rate of 24.1 per 1000 male population of Kabul city and the labour force replacement ratio was found to be 225. 


\section{CHAPTER V}

COMPOSITION OF ECONOMICALLY ACTIVE POPULATION 
5.1. INTRODUCTION

This chapter deals with the structure and characteristics of economically active population in Kabul city. The following characteristics are taken into consideration : age, sex, education, marital status (only for females), Industry and occupation. It also examines the migrant-non-migrant differences in occupations.

\subsection{AGE-SEX COMPOSITION}

The age pyramid, given in Figure 5.1, makes the age-sex composition of economically active population in Kabul city in 1986 abundantly clear. About 41 percent of the total economically active population was below 30 years of age, showing a low level compared to that of Tehran city which is 44.5 percent. The share of economically active population aged 65 years and above was 4.3 percent which is almost double the corresponding figure of Tehran city -2.3 percent.

The total economically active population of Kabul city was $317871^{1}$ of which the share of females was 10.7 percent which is more or less the same with that of Tehran city (11.77\%), showing low female work participation in both cities. However, a comparison with the 1965 situation has shown that the share of female workers in the labour force of Kabul city during the 21 year period between 1965 and 1986 has increased more than two times, as in 1965 it was only 4.87 percent. But it is still very low.

The sex ratio of the economically active population also help to show the low participation of females in economic activities. In Kabul, there were 832 male economically actlve population for every 100 female economically active population. This ratio does not differ very much from the corresponding figure for Tehran city (749). The low level 


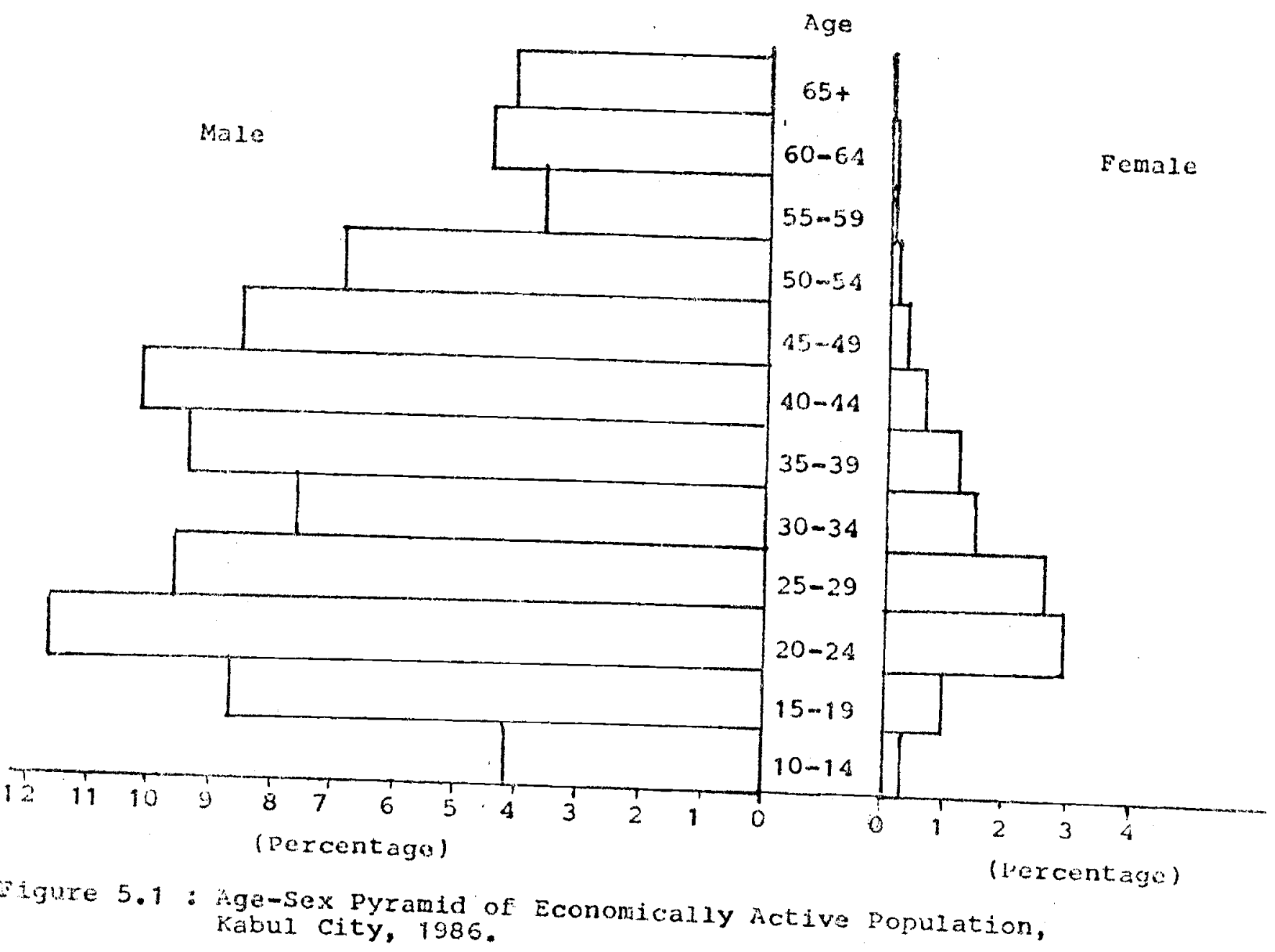


of the females in the labour force is mainly because of the cultural barriers. These are male dominant societies in which females are not expected to involve themselves in production activities as it is viewed as the monopoly of males. The low status of women and the large family size also does not enable them to enter labour force. However, the sex ratio of economically active population of Kabul city has decreased considerably from the level that prevalled in 1965, as in 1965 there were 1955 male workers per 100 female workers. It is a good sign of development.

The sex ratio of the economically active population for the different districts is given below in Table 5.1. The highest (1413) and lowest (517) sex ratio of economically active population were observed in sixth and third districts respectively. The difference in

Table 5.1 Sex-ratio of economically active population by districts, Kabul city, 1986

\begin{tabular}{lllllllllllll} 
District & 1 & 2 & 3 & 4 & 5 & 6 & 7 & 8 & 9 & 10 & 11 & $\begin{array}{c}\text { Kabul } \\
\text { City }\end{array}$ \\
\hline
\end{tabular}

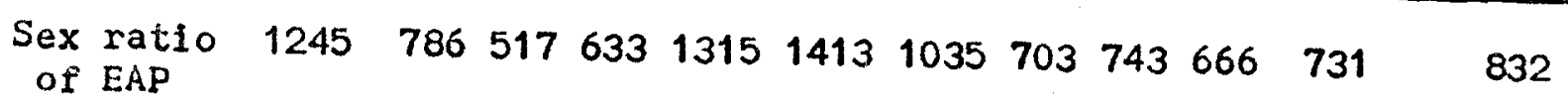

EAP : Economically active population. Source: Conputed from the same source of Table $3.1, p p .37,56,71,81,103$,
$119,135,152,169,185,201,218$.

female education may be one of the possible reasons for this, as the lowest (24.72\%) female literacy rate was found in sixth district while the fermales of the third district had the highest (47.40\%) literacy rate in the whole city. The comparatively lowest level of fertility (TCtal fertility rate $=5.02$ ) in third district also enable its female inhabitants to enter labour force. 


\subsection{EDUCATIONAL COMPOSITION}

Around 65 percent of the total economically active population of Kabul city in 1986 were literate, indicating a very high literacy rate corpared to the literacy rate of economically active population of the country (18.79\% in 1979). But this, when compared to the literacy rate of economically active population of Tehran city (74.41\%), was corm siderably low. The male-female literacy differential, unlike of total population, in economically active population is in favour of females. The literacy rate of male workers was 62.4 percent and that of females 82.6 percent. The corresponding figures for Tehran city works out to be 73.4 percent and 82.3 percent. This indicates that in both cities, females with some level of education were interested in work participation and had comparatively better opportunity to enter in labour force. The gap between male-female Iiteracy rates is much wider for Kabul city and the same is clearly shown in Figure 5.2 .

The percentage distribution of economically active population by level of educational attainment and industry is presented in table 5.2 This table reveals that the majority of the workers in agriculture and husbandry, quarrying and mining and in food and beverages industries wero iliterate among both males and females. It is true only in agriculture for Tehran city where 54 percent of total labour force was 1111 terate.

The proportion of 1111 terate workers was much higher for males compared to females in all industries. Among the educated workers the secondary school level education predominates - constituting about 22 percent of the total work force. But in Tehran city, among the educated economically active population, primary education level predominates forming nearly 19 percent of the total workers. This shows that in Kabul city the highest proportion of working population was better educated 


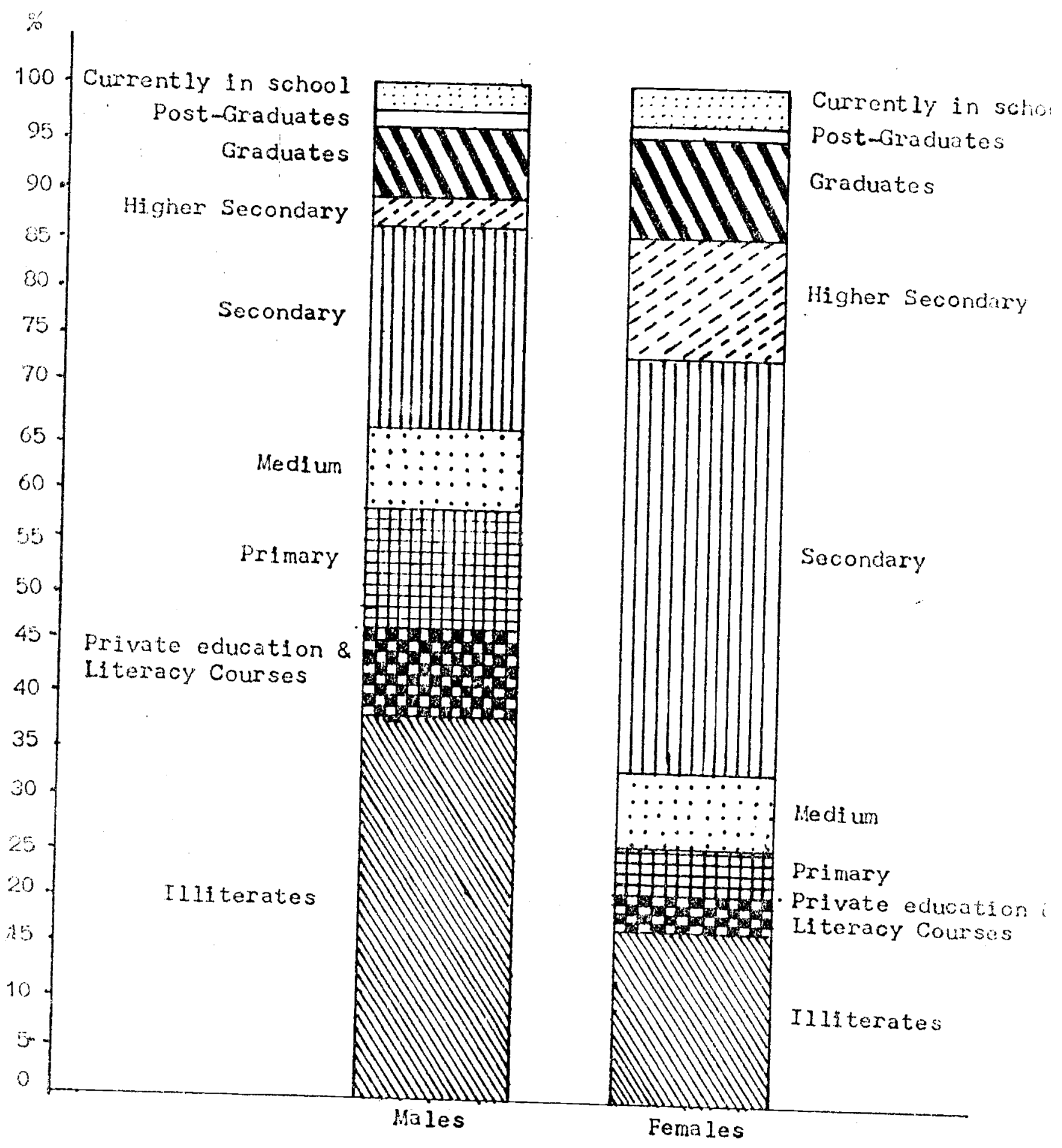

Flyure 5.2 Distribution of Male and Fernale Workers by Completed Level of Education, Kabul City, 1986 


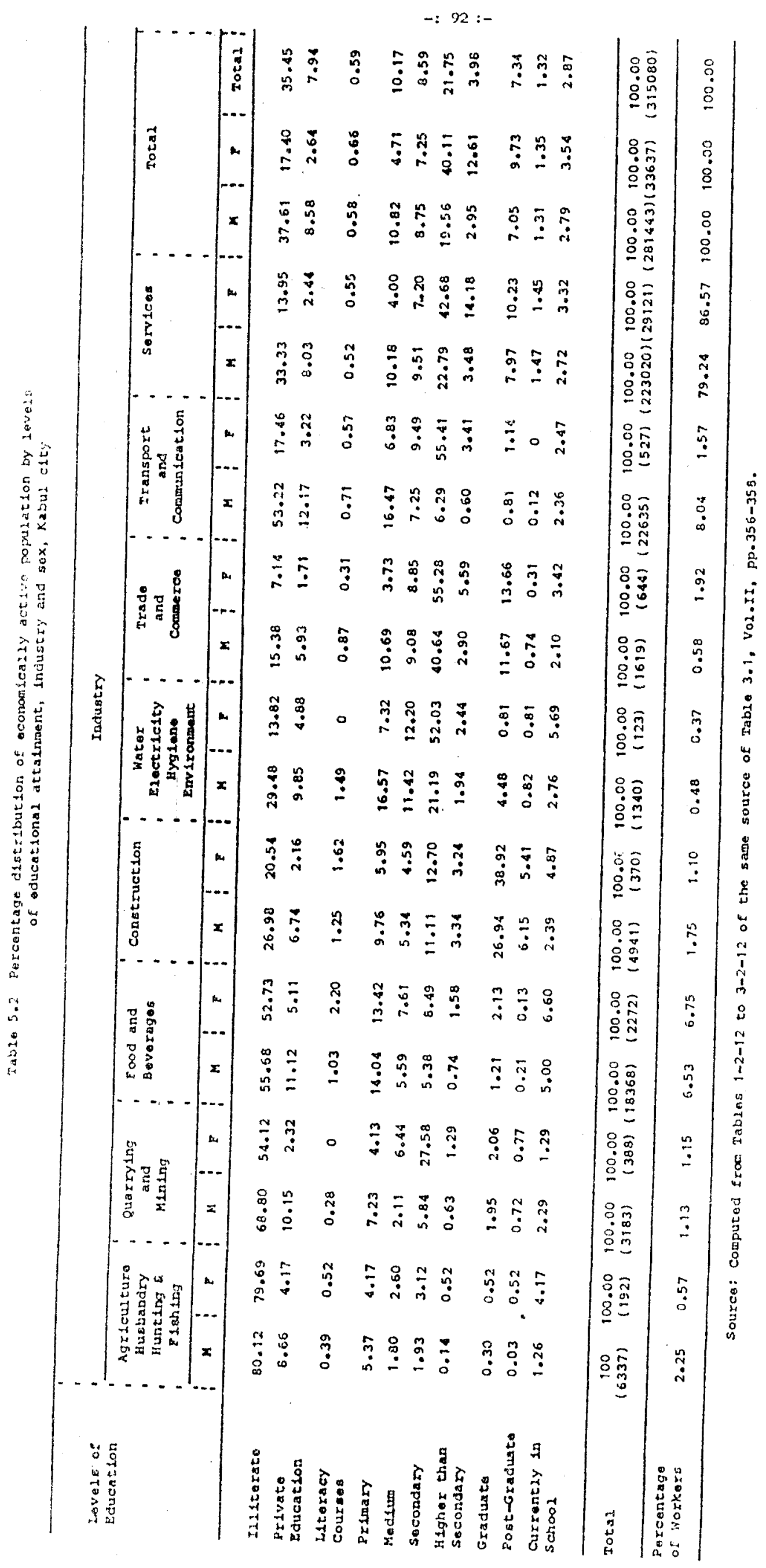


than that of Tehran city.

Tho post-graduates have only a share of 1.31 and 1.35 percent In labour force for males and females respectively. This share is low compared to the corresponding figures for Tehran city - 2.50 percent for males and 2.68 percent for females. One possible reason, besides comparatively less higher educational facilities, may be the out-migration of workers of this educational category from Kabul city because of political situation.

More than 85 percent of the total literate workers were workIng in service sector which constitutes 80 percent of the total econowically active population of Kabul city.

\subsection{MARITAL STATUS COMPOSITION}

The marital status composition of the economically active population is given in Figure 5.3. Currently married women farmed the majority with 55 percent and never married women formed the second largest group. This distribution is more or less the same as that of total fomale population. The nominal share of divorcees were mainly because in the total population itself there were only very few divorcees.

An examination of the distribution of economically active female population by marital status and occupation (Table 5.3) reveals an interesting pattern. Half of the currently married women were professional, technical and related workers. It is surmised that in a society where female work participation is not generally accepted, most of those who work must be educated and thereby appreciate the importance of work. Married women already have an earning member in the family, the male member; and probably they would be willing to take up a job if it suited their education. If clerical jobs were added to professional, technical 


$$
-94:-
$$

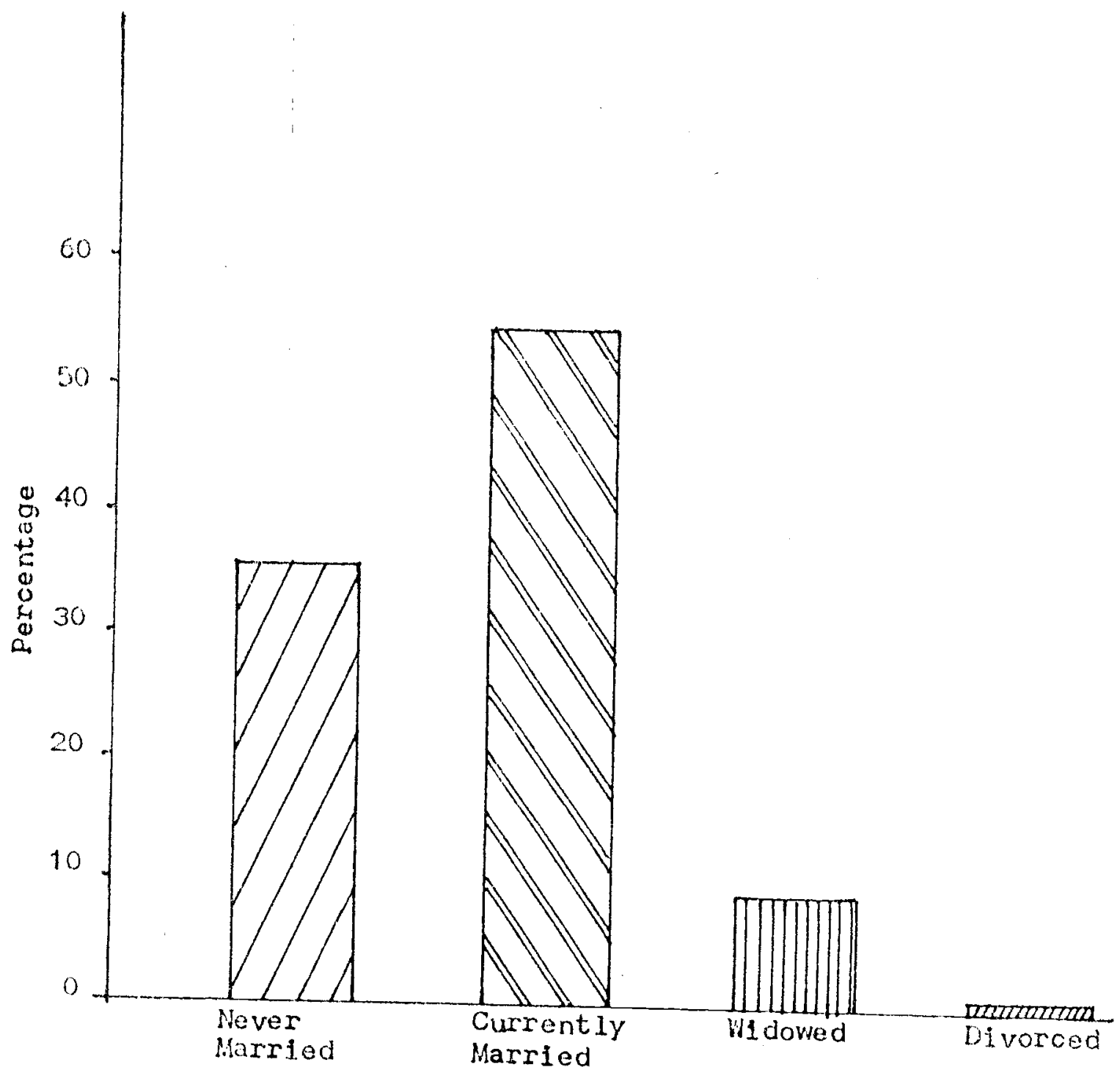

Figure 5.3. Warital Status Composition of Economically Active Fenale population, Kabul City, 1986 
Table 5.3 Percentage of economically active female population by marital status and occupation, Kabul city,1986

\begin{tabular}{|c|c|c|c|c|c|c|}
\hline \multirow{2}{*}{ Occupation } & \multicolumn{6}{|c|}{ Marital Status } \\
\hline & $\begin{array}{l}\text { Never } \\
\text { Marri- } \\
\text { ed }\end{array}$ & $\begin{array}{l}\text { Current- } \\
\text { ly Marr- } \\
\text { led }\end{array}$ & $\begin{array}{l}\text { Widow- } \\
\text { ed }\end{array}$ & $\begin{array}{l}\text { Divorc- } \\
\quad \text { ed }\end{array}$ & $\begin{array}{l}\text { Unspe- } \\
\text { cifled }\end{array}$ & Total \\
\hline $\begin{array}{l}\text { Professional, Tech- } \\
\text { nical and related } \\
\text { workers }\end{array}$ & 35.68 & 49.36 & 15.03 & 31.82 & 60.00 & 41.31 \\
\hline $\begin{array}{l}\text { Administrative and } \\
\text { managerial workers }\end{array}$ & 0.02 & 0.15 & 0.17 & 0.00 & 0.00 & 0.10 \\
\hline Clerical Personnel & 40.88 & 27.17 & 13.07 & 21.21 & 0.00 & 30.85 \\
\hline $\begin{array}{l}\text { Traders, shopkeepers } \\
\text { and other sellers }\end{array}$ & 0.79 & 0.66 & 0.60 & 0.00 & 0.00 & 0.70 \\
\hline $\begin{array}{l}\text { Hotels and Restaur- } \\
\text { ent workers }\end{array}$ & 1.81 & 3.75 & 13.13 & 7.58 & 0.00 & 3.89 \\
\hline $\begin{array}{l}\text { Agriculture and Hus- } \\
\text { bandry workers }\end{array}$ & 0.25 & 0.09 & 0.20 & 0.00 & 10.00 & 0.16 \\
\hline $\begin{array}{l}\text { Productions and Trans- } \\
\text { port workers and } \\
\text { operators }\end{array}$ & 20.58 & 18.82 & 57.80 & 39.39 & 30.00 & 22.99 \\
\hline Total & $\begin{array}{l}100.00 \\
12173)(\end{array}$ & $\begin{array}{r}100.00 \\
(18380)\end{array}$ & $\begin{array}{l}100.00 \\
(3008)\end{array}$ & $\begin{array}{l}100.00 \\
(66)\end{array}$ & $\begin{array}{c}100.00 \\
(10)\end{array}$ & $\begin{array}{r}100.00 \\
(33637)\end{array}$ \\
\hline
\end{tabular}

Source: Computed from Tables $01-2-11$ to $06-2-11$ of the same source of Table 3.1, Vol.II, pp.341-346.

and related workers, three-fourth of the workers are accounted for. Similar is the case of never married women, except that a large proportion is found in the olerical job and professional, technical and related jobs takes the second rank. A large share of widows were found in the non-modern sector activities. Perhaps they take up jobs after the widowhood and entry into modern sector occupation w1 11 be comparatively difficult because of the age factor involved. Half the divorced women were in the modern sector. It would appear that they might have obtained divorce as they are economically secure. That is, majority of these wowen must have been working while they obtalned divorce as most of 
modern sector occupations have age limitation in entry. The large share in production and transport work must be of those who took up jobs after divorce to make both onds meet as entry into these occupations generally do not have much problems.

\subsection{INDUSTRIAL COMPOSITION}

The percentage distribution of economically active population by industry and district is given in Table 5.4. The table shows that 80 percent of the total economically actlve population were engaged in service sector and among the different districts it varied only between 77 percent and 83 percent. In other words, the variation was not vary high. This share in service sector was considerably more than its share of 53 percent in 1965. The percentage of workers in service sector of Kabul city in 1986 is almost doublo of the corresponding percentage of Tehran city - 41.4. This high proportion is generally the result of transition of labour force to this seotor from other sectors which occurs in the course of development, particularly at an advanced stage (Turnhain and Jaeger 1971, Standing, 1978).

In Kabul, which is not a very advanoed society, all these workers may not be engaged in generally accepted service activities like education, medical, finance, Insurance and other social and personal service. But this cannot be varified as subdivision of service sector are not givei in the data set. It is, therefore, suspected that this large share in service sector could be due to (1) the inclusion of manufacturing activas ities and/or (2) an increased share of informal sector activities. The latter seems to be the trend in many of the big cities of less developed countries (Sethuraman, 1976). 


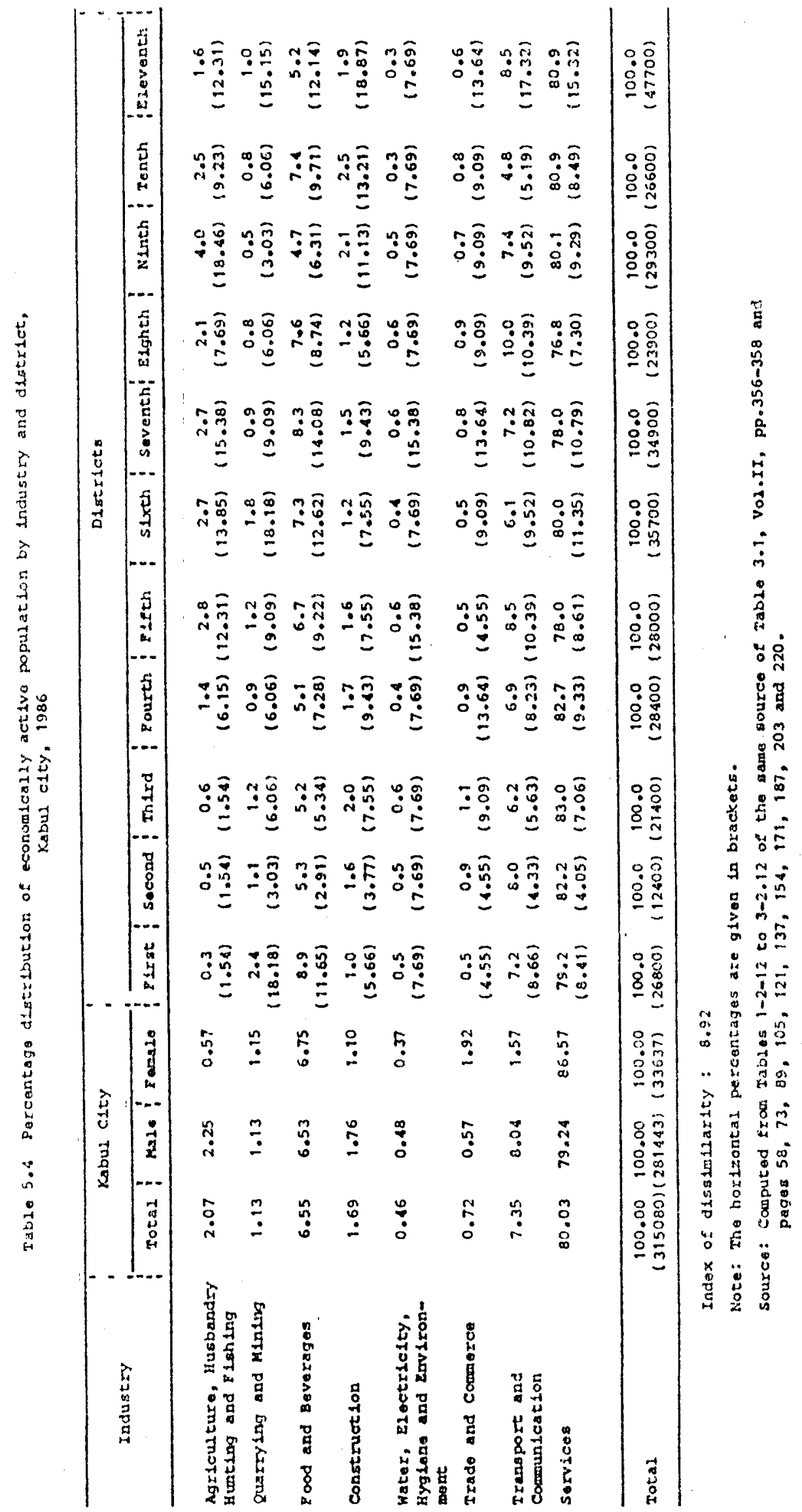


In absorbing labour force, Industries related to transport and communication had the second place. Its share in total economlco ally active population has increased from 3.3 percent in 1965 to 7.4 percent in 1986 which is more or less similar to the corresponding figure of Tehran city -8.5 percent. The highest percentage (10\%) or the workers in transport and communication was found in eighth disto rict. It is mainly because of the majority of migrants (especially from southern part of the country) settled in this district are traditionally transport workers.

The food and beverages industry, with a share of 6.6 percent in total economically active population, hold the third position and more economically active population of the first district were engaged in this type of economic activities. But the majority of total city's labour force engaged in this sector (more than 14 percent) was found in seventh district.

Agriculture and related activities which had a share of 6.2 percent in total economically active population of Greater Kabul in 1965, absorbed only 2.1 percent of the total workers in 1986 . But it is still higher compared to the corresponding figure of Tehran city 0.94 percent. The highest percentage of the workers of this category was observed in ninth district, constituting nearly 19 percent of the total workers of the city, engaged in agriculture and related activities.

Similarly, the share of construction sector in total econom mically active population decreased from 5.2 percent in 1965 to 1.7 percent in 1986, indicating very low proportion of workers in this cate gory compared to that of Tehran city -8.6 percent. The main reason for this may be the effect of political situation and war which have 
not allowed the proper development of this sector. While the higher percentage of the workers of this sector was found in tenth district, the construction workers of eleventh district constitutes 19 percent of the total workers of the city engaged in this sector.

The male-female differential in the distribution of economically active population into different industries was common for all industries. Among them this gap was especially wider for service sector and transport and communication. The highest gap among the male and female proportion in service sector is also true for Tehran city (males : $37.0 \%$ and females : $74.9 \%$ ) and the difference was much higher than that in Kabul city.

In food and beverages industry, trade and commerce and service sector, the share of females among female workers was higher than the share of males among male workers. The index of dissimilarity of 8.92 shows that 8.92 percent of the workers, either males or females, wi 11 have to shift categories to make the distribution of males and females the equal. In sum, the differences in the industrial distribution of male and female workers were not much.

The pattern of distribution of workers in each di strict is more or less the same as that of the city. But, some concentration of workers of specific occupation in some districts was observed. For example, nearly three-fourths of the total agricultural workers were in 5 districts. Similarly, half the mining and quarrying workers were in first, sixth and eleventh districts. Forty-three percent of the construction workers were in ninth, tenth and eleventh districts. Interestingly, except fifth and seventh districts all other districts have exactly the same share of water, electricity, hygiene and environment. 


\subsection{OCCUPATIONAL COMPOSITION}

There are seven major ocoupational divisions used in 1986 census and the distribution of economically active population into these divisions for different districts and for the whole city (by sex) are given in Table 5.5 .

slightly over half of the total economically active population fall into one category, viz. production-related workers. The share of this sector is usually higher than the proportion of workers in other occupational divisions. In Tehran it was 35 percent. The United Nations (1985) found in 1960 s and 1970 s in many cities in less developed countries the share of this sector varying between 30 to 50 percent. In Kabul, probably, it is because of the increase in the number of transport workers and operators, especially during 7 years period between 1979-86.

In general, occupational pattern was more or loss the same for all districts. Even then some existing differences of concentration of workers of different occupational groups is worth noting. The share is also given in Table 5.5 in peranthesis.

More than half $(52.1 \%)$ of the professional, technical and related workers were concentrated in four districts, viz. eleventh, ninth, third and fourth districts. While about 41 percent of clerical workers were found in eleventh, seventh and ninth districts, almost half of the administrators and managerial workers were the residents of the eleventh, ninth and seventh districts. Nearly three-fourths of the traders, shopkeepers and other sellers were living in 5 districts: first, sixth, fourth, eleventh and tenth. One-third of hotels and restaurant workers were found in eleventh and seventh districts. While 71 percent of the agrictanimal husbandry workers were concentrated in 


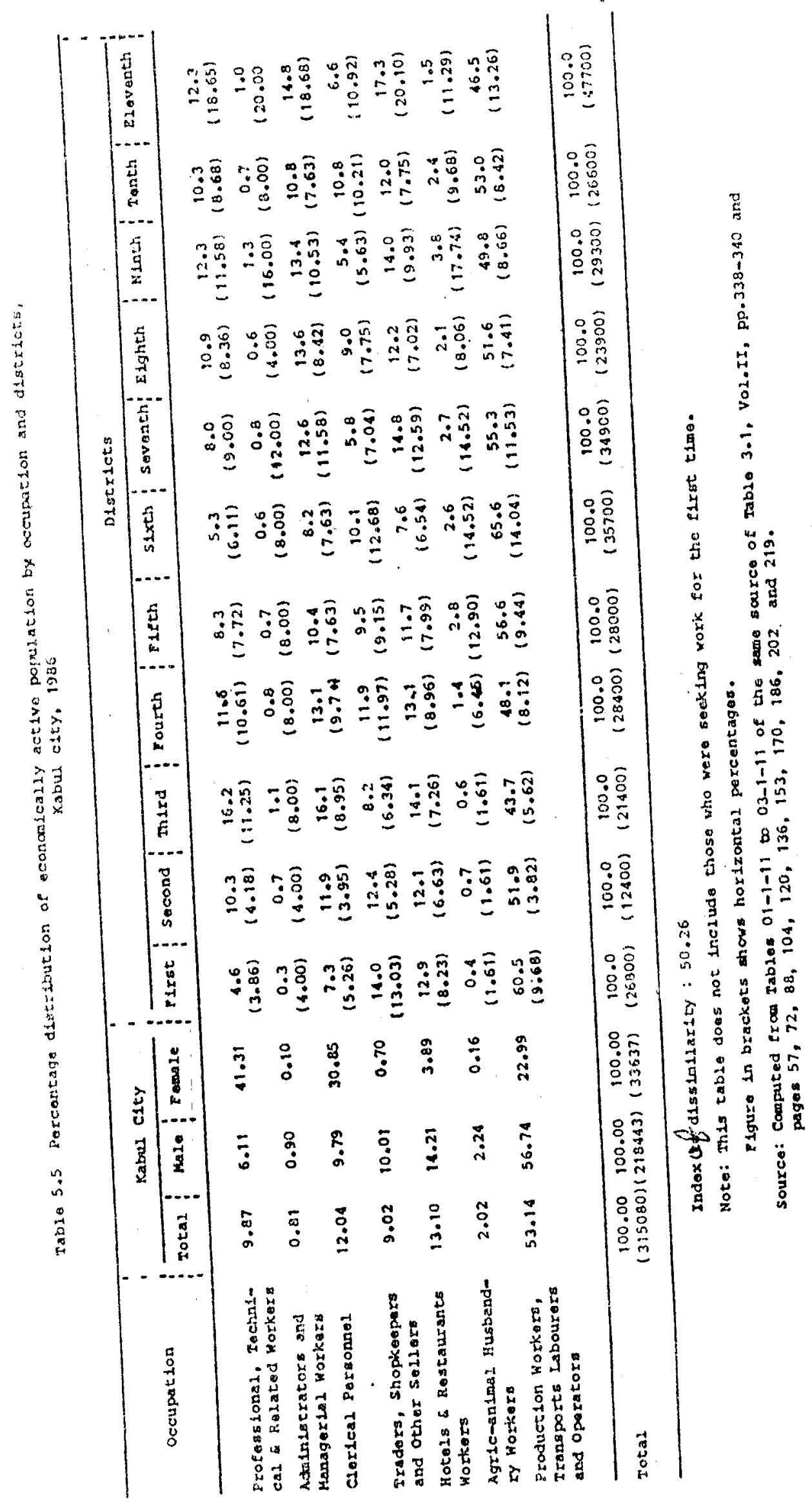


ninth, sixth, seventh, fifth and eleventh di stricts, almost two-fifths of the production-related workers were found in sixth, eleventh and seventh districts.

The male-female differential in occupational divisions is common for both Kabul and Tehran which follows almost the same pattern. The highest percentage of female labour force were professional, technical and related workers ( $41.31 \%$ in Kabul, $40.67 \%$ in Tehran) and of males production-related workers (56.74\% in Kabul, 39.34\% in Tehran). But the lowest percentage of working women in Kabul city was found to be administrative and managerial workers $(0.10 \%)$, whereas in Tehran agric-animal husbandry female workers constitute the lowest percentage of economically active women in this city $(0.13 \%)$.

Unlike industrial distribution, there was wide variation in the occupational distribution between male and female workers. The Index of dissiml larity was 56.26 showing the percentage of workers that have to shift occupations to make the two distributions the same.

\subsection{SEX-LABELLING OF OCCUPATIONAL CATEGORIES}

There is a tendency in all countries to consider certain jobs as "feminine" jobs. In Kabul city the extent to which this operates is obtained by using an index as mentioned in the methodology where the share of women in each occupational division is related to their share in total employment.

Table 5.6 shows this index for broad occupational categories. Professional, technical and related, clerical and production/related groups are where the share of women is very high compared to their overall share. Whereas administration, farming and trade were areas where womens' share was really low. These being broad categories, detalled 
situation is given in Table 5.7 .

Table 5.6 Index of female economic activity in broad occupational categories

\begin{tabular}{lrrr}
\hline \multicolumn{1}{c}{ Occupational Category } & \multicolumn{2}{c}{ Index } \\
& \multicolumn{1}{c}{ Kabul } & \multicolumn{1}{c}{ Tehran } \\
& 1986 & \multicolumn{1}{c}{1976} \\
\hline Professional, Technicians and Related Workers & 386.94 & 350.29 \\
Administrators and Managers & 0.95 & 6.01 \\
Clerical Personnel & 288.97 & 237.63 \\
Traders, Shopkeepers and Other Sellers & 6.54 & 14.57 \\
Hotels and Restaurants Workers & 36.45 & 157.25 \\
Farmers and Husbandry Workers & 1.53 & 1.16 \\
Production Workers and Transport Labourers & 215.32 & 63.06 \\
and Operators & & \\
\hline
\end{tabular}

Sources: (1) Computed from Table 03-1-11 of the same source of Table 3.1, Vol.II, p.340; and

(2) Computed from Table 18, National Census of Population and Housing, November 1976, Tehran Sharestan, Serial No.3.

Women are very much under-represented in many occupations especially in occupations like launderers, dry-cleaners and pressers; poets, authors, journalists and related workers; Protective Service workers; Agric-animal husbandry workers; Hotels and Restaurants workers and proprietors; spinners, weavers and related workers - where almost 99 percent lower than the overall female proportion.

Teaching is the profession in which women have a very high share compared to their overall share in workers. The female percentage in this occupational category in 1986 vas more than three times as high as the share of females in total economic activity. The very high concentration of females in professional occupations is also the characteristic of many other Muslim cities. For example, the share was for 
Table 5.7 Index of female economic activity in occupational groups, Kabul city, 1986

Architects, Engineers and Related Technicians

4.68

Professional of Social Sciences and Related Workers

8.69

Medical, Dental and Other Related Workers

44.61

Jurists, Judges and Related Workers

2.65

Teachers

317.81

Workers in Religion

3.12

Poets, Authors, Journalists and Related Workers

1.12

Clerical Workers

Sellers (Wholesale \& Retail Trade)

287.67

Hote 15 \& Restaurant Workers and Proprietors

5.43

1.48

Building Coretaicers, Cleaners and Related Workers

19.55

Launderers, Dry-cleaners and Pressers

1.11

Beauticians, Bath's Workers

2.95

Protective Service Workers

11.36

Agric-animal Husbandry Workers

1.39

Spinners, Weavers and Related Workers

1.64

Food and Beverage Processors

6.52

Tallors and Related Workers

26.05

Bricklayers, Carpenters and Other Construction Workers

3.43

Drivers of Transportation Means

11.17

Production and Related Workers not classified elsewhere 109.78

Other Workers whose occupation is not clessified

Source: Computed from Table 3-3-11 of the same source of Table 3.1 , Vol.II, p.351.

Algiers: 290 in 1966, Damascus: 339 in 1970, Karach1: 626 in 1970 and Tehran: 350 in 1976 (United Nations, 1985).

5.8. MIGRANTS AND THEIR WORK

Since two-fifths of the city's population are migrants, their work is exanined in brief in relation to the work of natives. 
Of the total migrants 65.58 percent were economically active and among them 6.39 percent were females. The share of migrant workers among total workers of the Kabul city was 58.50 percent, 33.39 percent and 55.82 percent for male, female and total respectively. The sex ratio of the migrant workers was 1465.83 males per 100 females.

Education by place of last work for migrant workers given in Table 5.8 makes three things clear: (1) among migrant workers 1111 teracy was high among males, (2) those whose place of last work was outside the country, a good proportion have higher level education and (3) those who came from Kabul province, their illiteracy was high. It shows that long distance migrants are mostly highly educated whereas it is not so for short distance migrants.

Table 5.8 Level of education of migrants by place of last work, Kabul city, 1986

\begin{tabular}{|c|c|c|c|c|c|c|c|c|}
\hline \multirow[t]{2}{*}{$\begin{array}{c}\text { Place of last } \\
\text { work }\end{array}$} & \multicolumn{2}{|c|}{ Ill1terate } & \multicolumn{2}{|c|}{$\begin{array}{c}\text { Secondary and } \\
\text { above }\end{array}$} & \multicolumn{2}{|c|}{ Others } & \multicolumn{2}{|c|}{ Total } \\
\hline & Ma le & Female & Male & Fema le & Male & Fema le & Male & Female \\
\hline Kabul Province & 45.9 & 39.0 & 23.4 & 41.6 & 30.7 & 19.4 & $\begin{array}{l}100.0 \\
(27611)\end{array}$ & $\begin{array}{l}100.0 \\
(1163)\end{array}$ \\
\hline Other Provinces & 541.0 & 30.0 & 29.9 & 51.3 & 29.1 & 18.7 & $\begin{array}{c}100.0 \\
(135435)\end{array}$ & $\begin{array}{l}100.0 \\
(9757)\end{array}$ \\
\hline $\begin{array}{l}\text { Outside the } \\
\text { country }\end{array}$ & 17.2 & 2.3 & 61.9 & 89.7 & 20.9 & 8.0 & $\begin{array}{l}100.0 \\
(1586)\end{array}$ & $\begin{array}{l}100.0 \\
(311)\end{array}$ \\
\hline
\end{tabular}

Source: Computed from Tables 2-5-7 and 3-5-7 of the same source of Table 3.1, Vol.II, pp.316-317.

The high proportion of iliterates among male migrants may be due to the fact that males being the accepted bread winners of the fam11y, will be on the lookout for jobs and will accept any jobs that they can get; whereas among females it is mostly educated women who seek job as their income is considered to be supplementary in nature (standing, 


$$
-106:-
$$

The occupations of non-migrants and migrants are likely to differ because of the possible differences in their characteristics and available job opportunities. In Table 5.9 is given occupational composition of migrants and non-migrants separately.

Table 5.9 Percentage distribution of migrants and non-migrants by sex and occupational divisions, Kabul city, 1986.

\begin{tabular}{|c|c|c|c|c|c|c|}
\hline \multirow{2}{*}{$\begin{array}{c}\text { Occupational } \\
\text { Divisions }\end{array}$} & \multicolumn{3}{|c|}{ Migrants } & \multicolumn{3}{|c|}{ Non-migrants } \\
\hline & Male & Fema le & Total & Ma le & Fema le & Tota 1 \\
\hline $\begin{array}{l}\text { Professionals } \\
\text { \& Techniclans }\end{array}$ & 6.21 & 36.00 & 8.12 & 5.95 & 43.97 & 12.07 \\
\hline $\begin{array}{l}\text { Administrators } \\
\text { and Managers }\end{array}$ & 1.04 & 0.18 & 9.98 & 0.70 & 0.06 & 0.60 \\
\hline $\begin{array}{l}\text { Clerical Per- } \\
\text { sonnel }\end{array}$ & 9.09 & 21.55 & 9.89 & 10.79 & 35.51 & 14.77 \\
\hline $\begin{array}{l}\text { Traders, Shop- } \\
\text { keepers and } \\
\text { Other Sellers }\end{array}$ & 11.10 & 0.97 & 10.46 & 8.47 & 0.56 & 7.20 \\
\hline $\begin{array}{l}\text { Hotels \& Res- } \\
\text { taurant Work- } \\
\text { ers }\end{array}$ & 17.60 & 6.20 & 16.87 & 9.41 & 2.74 & 8.34 \\
\hline $\begin{array}{l}\text { Cultivators } 8 \\
\text { Husbandry } \\
\text { Workers }\end{array}$ & 1.90 & 0.26 & 1.79 & 2.73 & 0.12 & 2.30 \\
\hline $\begin{array}{l}\text { Productions, } \\
\text { Transports } \\
\text { Workers and } \\
\text { Operators }\end{array}$ & 53.06 & 34.84 & 51.89 & 61.95 & 17.04 & 54.72 \\
\hline
\end{tabular}

\begin{tabular}{lcccccc}
\hline Total & 100.00 & 100.00 & 100.00 & 100.00 & 100.00 & 100.00 \\
& $(164642)$ & $(11232)$ & $(175874)$ & $(116801)$ & $(22405)$ & $(139206)$ \\
\hline
\end{tabular}

$\begin{array}{ll}\text { Index of Dissimilarity } & \text { Male : } 11.42 \\ \text { (migrant Vs. non-migrant) } & \text { Female: } 21.93\end{array}$

Source: Computed from Table 0-6-7 of the same source of Table 3.1, Vol.II, p.318.

The patterns are more or less the same for both groups. Between male and female migrants and non-migrants, the difference was more pronounced among females. While nearly four-fifths of female nonmigrants were in modern sector employment, migrant females were less 
than two-thirds in these occupational groups. Besides these production and related work absorbs a sizeable proportion of female migrafits. tion. It is a question of opportunity. There is a high concentration of male migrant and non-migrant workers in the production and related category. But the share of workers absorbed in the hotels and restaurants was almost double for migrants than for non-migrants.

The proportion of workers in certain occupational divisions is small and, therefore, in these groups absolute differences between the percentages for migrants and non-migrants may not be large even though in relative terms the differences are great. Using as an index the relative difference between percentages for migrants and for nonmigrants (Zachariah, 1968), the following differences in occupations are obtained for migrants and non-migrants (Table 5.10).

Table 5.10 Relative difference in occupational divisions for migrants and non-migrants, Kabul city, 1986

\begin{tabular}{lrrr}
\hline \multirow{2}{*}{ Occupational Divisions } & \multicolumn{3}{c}{ Relative Difference } \\
\cline { 3 - 4 } & Male & Female & Total \\
\hline Professional and Technicians & 4.44 & 19.93 & 39.13 \\
Administrators and Managers & 39.08 & 100.00 & 48.10 \\
Clerical Personnel & 17.10 & 48.93 & 40.56 \\
Traders, Shopkeepers and Other Sellers & 28.05 & 53.59 & 36.92 \\
Hotels and Restaurants Workers & 60.70 & 77.40 & 67.67 \\
Cultivators and Husbandry Workers & 35.39 & 73.68 & 24.92 \\
Production, Transports Workers & 15.46 & 200.00 & 5.31 \\
and Operators & & & \\
\hline
\end{tabular}

Source: Computed from Table 0-6-7 of the same source of Table 3.1 , Vol.II, P.318.

The above table reveals that for females: (1) very high difference in the'Production/related workers' and 'Administrator and Managers' groups; (2) high difference in the division of 'Hotels and Res- 
taurants workers' and (3) low difference in the divisions of 'Cultivators and Husbandry workers', 'Traders, Shopkeepers and other Sellers' and 'Clerical Personnel'. For males all occupational divisions except first and last had low differences. Very low difference is observed in the 'Professional and Technicians' for both males and females and in the group of 'Production. Transports workers and Operators' for males only. In sum, migrant-non-migrant differences are high among fernales than for males.

Since the pattern is more or less the same for both migrants and non-migrants, the share of migrants in each occupation category was examined (see Table 5.11). Interestingly, half or more of all occupational categories were manned by migrants. It would have been ideal if one could examine which are the exact occupations in which

Table 5.11 Share of migrants workers among total workers in each occupational group, Kabul city, 1986

\begin{tabular}{llcc}
\hline \multirow{2}{*}{ Occupational Divisions } & \multicolumn{3}{c}{$\begin{array}{c}\text { Share of Migrant } \\
\text { Workers }\end{array}$} \\
\cline { 2 - 4 } & Male & Female & Total \\
\hline Professionals and Technicians & 59.56 & 29.10 & 45.94 \\
Administrators and Managers & 67.54 & 64.71 & 67.50 \\
Clerical Personnel & 54.29 & 23.33 & 45.83 \\
Traders, Shopkeepers and Other Sellers & 64.88 & 46.38 & 64.73 \\
Hotels and Restaurants Workers & 72.50 & 53.17 & 71.89 \\
Cultivators and Husbandry Workers & 49.50 & 52.73 & 49.53 \\
Productions, Transports Workers & 54.69 & 50.61 & 54.50 \\
and Operators & & & \\
\hline Total & 58.50 & 33.39 & 55.82 \\
\hline
\end{tabular}

Source: Computed from Table 0-6-7 of the same source of Table 3.1 , Vol.II, p.318.

they are accommodated. But the available data set does not permit this kind of analysis. 


\subsection{SUMMARY}

An examination of the composition of economically active population of Kabul city shows that in 1986 a large proportion of the labour force consists of adult males. Only 8 percent of the females aged 10 years and above were economically active forming 10.7 percent of the total labour force. The sex ratio of economically active population was 832 which also shows the low participation of females in economic activities. The sex ratio varied between 1413 in sixth district and 517 in third district.

About 65 percent of the total economically active population in Kabul city were literate. The male-female literacy differential, unlike the total population, in economically active population is in favour of females.

More than half of the economically active female population were currently married and among them half were working in professional, technical and related activities. When clerical and related activities were also included, three-fourths of the married women workers are accounted for. Half the widows were found in the non-modern sector activities.

Eighty percent of economically active population were engaged in service sector. The male-female differential in the distribution of workers into different industries was common for all industries, especially so for service sector and for transport and communication. The pattern of distribution of workers in each district was more or less the same as that of the city.

Slightly over half of the total economically active population were production/related workers. Unlike industrial distribution, 
there was wide variation in the occupational distribution between male and female workers, as the index of dissimllarity was 56.26.

Professional, technical and related, clerical and production/ related groups are where the share of women is very high compared to their overall share; while administration, farming and trade were areas where the share of women was really low.

Of the total migrants nearly 66 percent were economically active and among them 6.39 percent were females. The share of migrant workers among total workers of Kabul city was $58.50,33.39$ and 55.82 percent for males, females and total respectively. The sex ratio of the migrant workers was 1465.83 males per 100 females. The migrant-non-migrant differences in occupation was more pronounced among females. While nearly four-fifths of female non-migrants were in modern sector activities, migrants were less than two-thirds in these occupational groups. Half or more of all occupational categories were manned by migrants. 


\section{CHAPTER VI}

UNDERUTILIZATION OF LABOUR 


\subsection{INTRODUCTION}

Under-utilization of human resources is a major problem in Afghanistan as in many other underdeveloped countries. In economic terminology, waste of labour or under-utilization of human resources is commonly discussed in terms of unemployment and underemployment. In the recent past "discouraged workers" also got included in this categary. In the main-strean of economic theory under-utilization of labour on a large scale is regarded as a primary cause of poverty in the underdeveloped countries. This large volume of unutilized labour has a productive potential that can be used to eliminate poverty (Roy, 1983). For an underdeveloped country like Afghanistan with surplus population and general shortage of social and private capital different and, in many respects, more formidable problems are apt to arise. The available data in Kabul city suggests that under-utilization of labour is not considerable compared to that in many other countries. This is a doubtful situation unless the war is playing a direct or indirect role in reducing the magnitude of underutilization. All the same, it appears that the situation should be viewed as not the actual situation but as the absolute minimum under-utilization in the city. Also it will become a serious problem in the near future if the present rate of population growth continues.

In this chapter, an attempt is made to discuss the situation of the under-utilization of human resources - unemployment/underemployment in Kabul city with the help of very limited data, collected in this regard in the 1986 population census. 
6.2. UNENPLOYMENT

Unemployed persons, according to 1986 Kabul Census, consist of all persons who, during the reference period, were not working but who were seeking work for pay or profit, including those who never 1 worked before. The unemployment rate in Kabul city was 3.17 percent, 3.15 percent for males and 3.30 percent for females. The age-specific unemployment rate for Kabul and Tehran is given in Table 6.1. The ta.ble reveals slightly higher unemployment rate for Tehran. But for cities of less developed countries, the rates are quite low. For exarnple, as pointed out in Chapter II, Brazil, in 1983, had an unemployment rate of 6.4 percent; urban Panama had 5.7 percent for the same year.

Table 6.1 Age-specific unemployment rates for Kabul and Tehran

\begin{tabular}{l|rrrrrrr} 
Age & \multicolumn{3}{c}{$\begin{array}{c}\text { Kabul City } \\
(1986)\end{array}$} & & \multicolumn{3}{c}{$\begin{array}{c}\text { Tehran City } \\
(1976)\end{array}$} \\
\cline { 2 - 6 } & Male & Female & Total & Male & Female & Total \\
\hline $10-14$ & 13.24 & 24.51 & 13.95 & 14.70 & 19.12 & 15.44 \\
$15-19$ & 2.30 & 7.83 & 2.85 & 11.85 & 21.78 & 12.91 \\
$20-24$ & 2.10 & 2.78 & 2.24 & 7.32 & 7.52 & 7.35 \\
$25-29$ & 1.81 & 1.37 & 1.72 & 2.71 & 2.52 & 2.68 \\
$30-34$ & 1.91 & 1.00 & 1.16 & 1.14 & 1.33 & 1.16 \\
$35-39$ & 1.57 & 1.59 & 1.57 & 0.66 & 0.92 & 0.68 \\
$40-44$ & 2.01 & 2.28 & 2.02 & 0.54 & 1.05 & 0.58 \\
$45-49$ & 2.25 & 2.36 & 2.26 & 0.71 & 0.93 & 0.73 \\
$50-54$ & 3.02 & 4.61 & 3.07 & 0.97 & 0.86 & 0.96 \\
$55-59$ & 3.67 & 4.82 & 3.69 & 1.24 & 1.14 & 1.23 \\
$60-64$ & 5.15 & 13.31 & 5.29 & 1.99 & 1.59 & 1.95 \\
$65+$ & 10.17 & 21.03 & 10.35 & 4.18 & 3.03 & 4.06 \\
\hline Total & 3.15 & 3.30 & 3.17 & 3.54 & 5.06 & 3.72 \\
\hline
\end{tabular}

Source: (1) Computed from Tables 01-1-10 to 03-1-10 of the same source of Table 3.1, Vol.II, pp.329-331.

(2) Computed from Table 16, p.190 of National Census of Population and Housing 1976, Tehran Sharestan.

1 The ratio of the number of unemployed persons, to the labour force expressed as a percentage. 
Greater Santiago in 1985 has shown an unemployment rate of 17.7 percent for the same year Manila had still higher rate - 22 percent. This table $(6 . i)$ reveals that the rate of unemployment was quite high among the young adults (aged 10-24 of Kabul city and 10-29 of Tehran city). This is true in other cities of less developed countries also. For example, in Brazil, those aged 10-17 years had the highest unemployment rate (Jatoba, 1989). This is only natural as they form the least experienced persons who enter the labour market for the fir st time in search of job. An examination of the age distribution of those who seek job for the first time in Kabul city 2/: substantiated this statement (see Table 6.2).

Table 6.2 Percentage distribution of persons seeking job for the first time by age group, Kabul city, 1986

\begin{tabular}{cccc}
\hline \multirow{2}{*}{ Age } & \multicolumn{3}{c}{ Unemployment rate } \\
\cline { 2 - 4 } & Male & Female & Tota 1 \\
$10-14$ & 42.51 & 19.52 & 38.37 \\
$15-19$ & 12.63 & 30.68 & 15.87 \\
$20-24$ & 15.33 & 30.88 & 18.13 \\
$25-29$ & 10.57 & 9.36 & 10.35 \\
$30-34$ & 2.88 & 2.79 & 2.87 \\
$35+$ & 16.08 & 6.77 & 14.41 \\
& 100.00 & 100.00 & 100.00 \\
\hline Total & $(2289)$ & $(502)$ & $(2791)$ \\
\hline
\end{tabular}

Source: Computed from Tables $01-1-10$ to $03-1-10$ of the same source of Table 3.1, Vol.II, pp.329-331.

In general, females had higher rate of unemployment than males; but the difference was much more in Tehran city. This may be reflecting the sex-wise preference of employers.

2) For Tenran city the data are not available. 
The percentage distribution of unemployed persons by age and sex (Table 6.3) also reveals that the higher proportion of unemployed persons in Kabul city falls in younger age group (10-14), constituting ahout 20 percent of total unemployed labour force; whereas only 5 percent of unemployed persons in Tehran city fall in this category and more than 68 percent of the total unemployed working population belongs to the age group of 15-24. The proportion of unemployed persons in older age group $(65, t)$ is also very high in Kabul city $(13.9 \%)$ compared to that of Tehran city $(2.51 \%)$.

Table 6.3 Percentage distribution of unemployed persons by age and sex

\begin{tabular}{rrrrrrrr} 
Age & \multicolumn{3}{c}{$\begin{array}{c}\text { Kabul City } \\
(1986)\end{array}$} & & & \multicolumn{3}{c}{$\begin{array}{c}\text { Tehran City } \\
(1976)\end{array}$} \\
& Male & Female & Total & Male & Female & Total \\
\hline $10-14$ & 19.85 & 19.80 & 19.85 & 4.74 & 6.55 & 5.31 \\
$15-19$ & 7.09 & 21.23 & 8.67 & 31.10 & 35.88 & 31.86 \\
$20-24$ & 8.70 & 23.00 & 10.30 & 36.34 & 36.56 & 36.37 \\
$25-29$ & 6.19 & 10.04 & 6.62 & 11.48 & 10.53 & 11.33 \\
$30-34$ & 3.23 & 4.17 & 3.34 & 4.04 & 3.68 & 3.98 \\
$35-39$ & 5.25 & 5.15 & 5.24 & 2.07 & 1.76 & 2.02 \\
$40-44$ & 7.33 & 3.91 & 6.95 & 1.60 & 1.42 & 1.57 \\
$45-49$ & 6.83 & 2.04 & 6.29 & 1.61 & 0.87 & 1.49 \\
$50-54$ & 7.36 & 2.75 & 6.85 & 1.83 & 0.65 & 1.45 \\
$55-59$ & 4.76 & 0.98 & 4.34 & 1.30 & 0.41 & 1.16 \\
$60-64$ & 8.25 & 2.99 & 7.65 & 1.15 & 0.46 & 1.04 \\
$65+$ & 15.50 & 4.00 & 13.90 & 2.75 & 1.23 & 2.51 \\
\hline Total & 100.00 & 100.00 & 100.00 & 100.00 & 100.00 & 100.00 \\
& $(8950)$ & $(1126)$ & $(10076)$ & $(41840)$ & $(7970)$ & $(49810)$ \\
\hline
\end{tabular}

Source: Same as Table 6.1.

Of the total number of unemployed persons of Kabul city, 88. 82 percent were males and the remaining 11.18 percent females. The corresponding figures for Tehran city work out to be 84.00 percent and 16.00 percent respectively. 
A heavy concentration of unemployed females (nearly two-thirds) In Kabul city was found in the 10-24 year age group; whereas more unemployed females (83\%) in Tehran city were concentrated in 15-29 year age group. While a large proportion of unemployed males (20\%) in Kabul city was below age 15 years, more than two-thirds of unemployed male population of Tehran city fall in 15-29 year age group.

The distribution of unemployed persons by type of unemploynent (Table 6.4) illustrates that in 1986 in Kabul city the majority of unemployed persons were seasonal. This actually reflects the situation prevailing among males as they form overwhelming majority. Among females

Table 6.4 The percentage distribution of unemployed persons by type of unemployment and sex

\begin{tabular}{|c|c|c|c|c|c|c|c|}
\hline \multirow{2}{*}{$\begin{array}{l}\text { Type of } \\
\text { unemploy- } \\
\text { ment }\end{array}$} & \multicolumn{4}{|c|}{$\begin{array}{l}\text { Kabul C1ty } \\
(1986)\end{array}$} & \multicolumn{3}{|c|}{$\begin{array}{c}\text { Tehran City } \\
(1976)\end{array}$} \\
\hline & Male & - Female & ! & Total & Male & : Female & : Total \\
\hline $\begin{array}{l}\text { Seasona } 1 \\
\text { unemploy- } \\
\text { went }\end{array}$ & 51.09 & 35.61 & & 49.36 & 3.59 & 2.87 & 3.47 \\
\hline $\begin{array}{l}\text { Currently } \\
\text { unemployed }\end{array}$ & 23.33 & 19.81 & & 22.94 & 16.23 & 15.77 & 16.16 \\
\hline $\begin{array}{l}\text { Seeking } \\
\text { work for } \\
\text { the first } \\
\text { time }\end{array}$ & 25.58 & 44.58 & & 27.70 & 80.18 & 81.36 & 80.37 \\
\hline Total & $\begin{array}{l}100.00 \\
(8950)\end{array}$ & $\begin{array}{l}100.00 \\
(1126)\end{array}$ & & $\begin{array}{r}100.00 \\
(10076)\end{array}$ & $\begin{array}{r}100.00 \\
(41840)\end{array}$ & $\begin{array}{l}100.00 \\
(7970)\end{array}$ & $\begin{array}{r}100.00 \\
(49810)\end{array}$ \\
\hline
\end{tabular}

Source: (1) Same as Table 6.1.

(2) Computed from Table 30 of the same source of Table 6.1 (2), p.310.

a large proportion was seeking job for the first time. The situation was found to be different in Tehran city where slightly more than fourfifths of the unemployed persons for total as well as for males and 
females separately fall in the category of "seeking job for the first time". The distribution of unemployed workers by type of unemployment in Tehran city seems to be a normal situation, found also in the urban centres of many other developing countries; while of Kabul city is a peculiar situation, most probably created by climatic factor and its less development.

The female unemployment rate by age and marital status

(Table 6.5) shows that the highest rate is for divorced women, followed by never-married group. Married women had the lowest unemployment rate. The highest unemployment rate of never married females was for the younger age group of 10-14. Among widowed and divorced females, unemployment rates were high in the 15-19 age group. While the unemployment rates of the first three categories of marital status, in age of 40 years and over increased with the increase of age, it is zero for divorced fernales. This is again a reflection of cultural situation where, especially in this age, self-supporting becomes indispensible for them and they have to accept any type of avaflable work that comes on their way; whereas others may not be accepting any but suitablo jobs.

Table 6.5 Female unemployment rates by age and marital status, Kabul city, 1986

\begin{tabular}{|c|c|c|c|c|c|}
\hline \multirow{2}{*}{$\begin{array}{l}\text { Age } \\
\text { Group }\end{array}$} & \multicolumn{5}{|c|}{ Marital Status } \\
\hline & $\begin{array}{l}\text { Never } \\
\text { Married }\end{array}$ & $\begin{array}{l}\text { Currently } \\
\text { Married }\end{array}$ & Wi dowed & Divorced & Total \\
\hline $\begin{array}{c}10-14 \\
15-19 \\
20-24 \\
25-39 \\
40-59 \\
60-64 \\
65+\end{array}$ & $\begin{array}{r}25.49 \\
7.86 \\
2.73 \\
1.68 \\
5.61 \\
10.00 \\
23.08\end{array}$ & $\begin{array}{r}3.70 \\
6.85 \\
2.75 \\
1.16 \\
3.06 \\
16.67 \\
18.82\end{array}$ & $\begin{array}{r}0.00 \\
23.53 \\
3.62 \\
1.27 \\
1.97 \\
11.11 \\
22.12\end{array}$ & $\begin{array}{r}0.00 \\
33.33 \\
30.00 \\
9.38 \\
0.00 \\
0.00 \\
0.00\end{array}$ & $\begin{array}{r}24.51 \\
7.83 \\
2.78 \\
1.31 \\
2.87 \\
13.31 \\
21.03\end{array}$ \\
\hline Total & 5.16 & 2.02 & 3.01 & 10.45 & 3.30 \\
\hline
\end{tabular}

Source: Computed from Tables 1-2-10 to 5-2-10 of same source of Table 3.1, Vol.II, pp.332-336. 
Of the total unemployed women of Kabul city, in 1986, 57.46 percent were never married, 33.22 percent were currently married, 8.08 percent were widowed and only 0.62 percent were divorced.

The percentage of unemployed females by age and marital status (Table 6.6) shows that while about 89 percent of never married unemployed women were below the age of 25 years, only less than 10 percent of widowed fall in this age group. Perhaps young widows get the support

Table 6.6 Percentage distribution of unemployed females by age and marital status, Kabul city, 1986

\begin{tabular}{ccccc}
\hline Age & \multicolumn{4}{c}{ Marital Status } \\
\cline { 2 - 5 } & $\begin{array}{c}\text { Never } \\
\text { Married }\end{array}$ & $\begin{array}{c}\text { Currently } \\
\text { Married }\end{array}$ & Widowed & Total \\
\hline $10-14$ & 34.31 & 0.27 & 0.00 & 19.81 \\
$15-19$ & 31.53 & 8.02 & 4.40 & 21.23 \\
$20-24$ & 23.03 & 27.27 & 5.49 & 23.00 \\
$25-29$ & 6.03 & 17.38 & 6.59 & 10.04 \\
$30-34$ & 1.55 & 8.29 & 5.50 & 4.17 \\
$35-39$ & 1.24 & 10.96 & 6.59 & 5.15 \\
$40-44$ & 0.46 & 7.22 & 14.29 & 3.91 \\
$45-49$ & 0.31 & 4.81 & 3.30 & 2.04 \\
$50-54$ & 0.46 & 4.81 & 9.89 & 2.75 \\
$55-59$ & 0.46 & 2.14 & 0.00 & 0.97 \\
$60-64$ & 0.16 & 4.55 & 16.48 & 2.93 \\
$65+$ & 0.46 & 4.28 & 27.47 & 4.00 \\
\hline & & & 100.00 & 100.00 \\
\hline Total & 100.00 & 100.00 & $(91)$ & $(1126)$ \\
\hline
\end{tabular}

Note: This table does not give age-specific unemployment rates for divorced and unspecified female since their share is negligible; but they are included in total.

Source: Computed from Tables 1-2-10 to 4-2-10 of the same source of Table 3.1, Vol.II, pp.332-335.

of their families thereby postponing the need for labour force participation. Nearly 45 percent of currently married unemployed females were in the age group of 20-29. The proportion of unemployed among widowed 3/ The total includes the 0.62 percent of unspecified unemployed females. 
was quite larger for women aged 60 years and over forming about 44 percent of the total. While the corresponding figure for currently married women works out to be nearly 9 percent, it was negligible (only 0.62 percent) for never married females.

The percentage distribution of unemployed females by type of unemployment and marital status (Table 6.7) reveals that the majority of unemployed females were those who were seeking work for the first time. The same is true for never married females; but the remaining categorles of marital status viz. currently married, widowed and divorced had their largest proportions in the "seasonal unemployed" category.

Table 6.7 The percentage distribution of unemployed females by type of unemploynent and marital status, Kabul city, 1986

\begin{tabular}{lccccc}
\hline \multirow{2}{*}{$\begin{array}{c}\text { Type of } \\
\text { Unemployment }\end{array}$} & \begin{tabular}{c} 
Never \\
\cline { 2 - 6 }
\end{tabular} & $\begin{array}{c}\text { Married } \\
\text { Marrently } \\
\text { Married }\end{array}$ & Widowed & Divorced & Total \\
\hline Seasonal unemployed & 29.83 & 37.17 & 62.64 & 71.43 & 35.61 \\
Currently " & 14.22 & 30.21 & 18.68 & 14.28 & 19.81 \\
Seeking work for & 55.95 & 32.62 & 18.68 & 14.29 & 44.58 \\
the first time & & & & & \\
\hline Total & 100.00 & $\begin{array}{c}100.00 \\
(374)\end{array}$ & $\begin{array}{c}100.00 \\
(91)\end{array}$ & $\begin{array}{c}100.00 \\
(7)\end{array}$ & $\begin{array}{c}100.00 \\
\text { (1126) }\end{array}$ \\
\hline
\end{tabular}

Note: The total includes 7 unspecified unemployed females. Source: Same as Table 6.5.

The unemployment rate was found to be different in different districts. It varies from a minimum of 1.61 percent in the second district to a maximun of 4.41 percent in ninth district (Table 6.8). One possible reason for this may be the different volume of migrants settled in these districts. While the volume of migrants is minimum (only 3.8 percent of the total migrants of the city) in the second district, it 
the distance from the centre of the city and low level of literacy, comparatively higher proportion of labour force in agriculture and related activities may also subscribe to higher unemployment rate in these districts. The main reason for the high unemployment rate of the eleventh district is its population explosion, especially due to in-migration. The highest percentage of the city's migrants $(17.65 \%)$ are settled in this district.

The male-female differential in unemployment rate is common for all districts. Among them this gap is highest for the sixth district where more than 8 percent of the total female labour force was unemployed. In general, the female unemployment rate in each district was higher than that of males, except in eleventh district where the reverse is true. This may be the outcome of the larger proportion of migrants in this district - constituting more than 54 percent of the total population of the district.

The share of each district in total unemployed persons of Kabul city was also found to be different (see last column ô Table 6.8). The eleventh district with a share of 17.65 percent had the highest share and the second district with a share of 2.94 percent had the lowest share. Sixth, ninth and fifth districts also had comparatively higher share.

\subsection{UIDEREMPLOYMENT}

Underemployment, in simple terms, means the under-utilization of a worker's time and/or skill. The necessary data are not available in the 1986 census. But an attempt is made to get some approximation of underemployment using the cross classification of occupation by education - assuming that it will give an idea of under-utilization of skill 


\section{$-: 121:-$}

There were altogether 39,828 highly educated persons in Kabul city, when "highly educated" is defined as higher secondary and above. of this, 31.51 percent were having higher secondary education, 58.06 percent were graduates and the remaining 10.43 percent were post-graduates. High level education is required mainly for modern sector employment. The following table (Table 6.9) shows the proportion of highIy educated persons engaged in modern and non-modern sector economic activities.

Table 6.9 Percentage distribution of highly educated persons by sector of economic activities

\begin{tabular}{|c|c|c|c|c|}
\hline \multirow{2}{*}{ Sector } & \multirow{2}{*}{$\begin{array}{l}\text { Levels of } \\
\text { Education }\end{array}$} & \multicolumn{3}{|c|}{ Sex } \\
\hline & & Male & Female & Total \\
\hline \multirow[t]{3}{*}{$\begin{array}{l}\text { Modern } \\
\text { Sector : }\end{array}$} & Higher Secondary & 45.07 & 98.04 & 63.00 \\
\hline & Graduates & 46.35 & 94.99 & 53.25 \\
\hline & Post-Graduates & 76.84 & 94.92 & 78.82 \\
\hline \multirow[t]{3}{*}{$\begin{array}{l}\text { Non-modern } \\
\text { Sector : }\end{array}$} & Higher Secondary & 54.93 & 1.96 & 37.00 \\
\hline & Graduates & 56.65 & 5.01 & 46.75 \\
\hline & Post-Graduates & 23.16 & 5.08 & 21.18 \\
\hline
\end{tabular}

Source: Computed from Tables $1-3-11$ to $3-3-11$ of the same source of Table 3.1, Vol.II, pp.247-252.

Modern sector is defined as professional, technical and related, administrative and managerial and clerical work. Among males there is a large amount of under-utilization of education as can be deduced from these figures. A large share of modern sector workers were found in clerical work. Nearly 21 percent each of both mable and female post-graduates were working as clerks and clerical work does not need post-graduate level of education. 
Similarly, in the occupations like cashiers, treasurers and contractors, book-keepers, sellers, building caretakers and cleaners for which a secondary or higher secondary level of education would be sufficient, relatively a good proportion of the workers having graduate or post-graduate level of education are found. Also a large chunk of workers were concentrated in teaching profession which varied from pre-primary to university level. If disaggregated data were available one could examine the extent of under-utilization.

Rapid growth of population, lack of proper growth strategy and inadequate planning seems to be contributing to this unhappy situation.

\subsection{SUMMARY}

The available data in Kabul city suggest that under-utilization of labour is not considerable compared to that in cities of many other countries; but it will become a serious problem in the near future if the present rate of population growth continues.

Unemployment rate in Kąbul city in 1986 was 3.17 percent: 3.15 percent for males and 3.30 percent for females. The age-specific unemployment rates show that the rate of unemployment was quite high among the young adults. This is also supported by the percentage distribution of unemployed persons by age. In general, females had higher rate of unemployment than males.

Of the total number of unemployed persons majority were males and seasonally unemployed. Among females, a large proportion was seeking job for the first time.

The female unemployment rate by age and marital status shows that the highest rate is for divorced women followed by never married 
group. The highest unemployment rate of never married females was found for the younger age group of 10-14. Among widowed and divorced females unemployment rates were high in the 15-19 age group. The unemployment rate of divorced at age 40 and above is zero.

Of total unemployed women of Kabul city in 1986, nearly

three-fourths were never married and one-third were currently married. Among the never married unemployed women, 89 percent were below the age of 25 years. Nearly 45 percent of currently married unemployed females were in the age group of 20-29. More unemployed widows were 60 years and above.

The unemp loyment rate was minimum in the second district and maximum in ninth district. The fifth and sixth districts had the second highest unemployment rates. The male-female differential in unemployment rate is common for all districts.

An examination of the occupation of educated persons revealed some underemployment. That is, many were working in occupations requiring lesser educational attainment than what they have. 


\section{CHAPTER VII}

\section{SUMMARY AND CONGLUSIONS}




\subsection{SUMMARY}

Kabul city has a rapidly growing population and in 1986 its population was $1,301,289$. This population is distributed among the eleven districts within the city. The overall density of the population has increased from 4373 persons per sq. Km. in 1979 to 6109 per-sons per sq. Km. In 1986. Since the area of each of the districts are not available, the density of each district could not be estimated.

The masculinity proportion of 1986 population was considerably low compared to the 1965 situation of Greater Kabul or 1976 situation of Tehran city. The overall sex ratio was found to be 103.9; but, an abnormally low sex ratio was found for the 15-39 age group (83 males per 100 females). The sex ratio of this age group in 1965 a normal situation, was 136 and of Tehran city in 1976 was 114.31. The main reason of this is the out-migration of adult males aged 15-39 during 1979-86 period because of military law according to which male population aged 18-39 must serve 5-7 years in army in two phases. Those who were not willing to serve in army in that circumstances were leaving the city.

Forty-eight percent of the total population of the city was in the $(0-14)$ age group making it a young population. This figure for Tehran city was found to be only 36.8 percent. The median age also was found to be considerably low in Kabul compared to that of Tehran. The sex-wise median age in 1965 and 1986 has shown a decline for males (mainly because of adult male out-migration) and a nominal increase for females. The age dependency ratio of 105 in 1986 was found ta be not only very high compared to that of Tehran city - 67; but it is higher than 1965 situation of Greater Kabul - 92. With a young age structure as found in Kabul city a high dependency ratio is natural. 
Nearly 45 percent of the total population belonged to never married category and that goes well with the age composition. Widowhood claims only a small share and the divorcees were almost negligible $(0.03 \%)$ which is significantly lower than that of Tehran city. Perhaps this is an indication of higher stability of family life in Kabul city compared to that of Tehran city. A comparison of married population in the 15-19 age group with the 1965 population census of Greater Kabul shows a considerable increase in age at marriage. The proportion of married population aged 15-24 of 1986 population of Kabul also was found to be lower than the corresponding figure of Tehran city showing a higher age at marriage for Kabul city population. But this increase in age at marriage could be due to a decline in the eligible bachelors who have out-migrated due to political/military consideration. The proportion of widows in each age group in the age interval of 15 to 39 years was very high compared to the female widowed in the same age group of Tehran city - reflecting the effect of war which usually increase the deaths of males of prime age.

The average household size was very high -6.62 persons; whereas this was only 4.61 persons in Tehran city. Nearly two-thirds of the houscholds had 6 persons or more. It is mainly because of two reasons - first is the high birth rate prevailing in the country and secondly, the economic difficulty in setting up new households coupled with the soclo-cultural acceptance of joint/extended family living arrangements. The average household size of the different districts also were more or less the same, 6-7 persons, except in the first district where it was only 5 persons. One reason for this could be the type of residential units available for the inhabitants of this district -58 percent of the total households had only one room; whereas 
a large number of households in other districts had two or more rooms. The effective literacy rate -50.6 percent (Males: $64.3 \%$, Females: $36.4 \%$ ) was found to be considerably lower than that of Tehran city. Though male-female literacy differential also was found in Tehran (males: $79.3 \%$, females: $66.0 \%$ ), the proportion of literate females is much higher in Tehran city. The comparison of the effective literacy rates of 1986 population of Kabul city with the 1965 situation of Greater Kabul shows a comparatively low growth of literacy in the city. Minority nationalities like Nooristani, Hindu and Uzbak had a higher literacy rate than others. The reason for this is that these minorities in Kabul city have comparatively favourable economic condition which enable them to attend to school. Male-female literacy differential is considerable for all nationalities. Among different districts the highest literacy rate was found in third district, mainly because of the comparatively higher concentration of educational institutions in this district. The lowest literacy rate was observed in the first district, the majority of the male inhabitants of which are traditionally shopkeepers and sales workers.

About 26 percent of the population aged 5 years and above have enrolled in school which is considerably lower than the corresponding figure of Tehran city -34.5 percent. Male-female differential in school enrolment was also found to be higher in Kabul city.

In each level of education, the share of males was higher than that of females. This is an expected pattern as in less developed countries the need for female education is seldom felt. Highly educated people formed only a very small proportion of the literate population even among males - the share of post-graduates was only 1.31 percent while of Tehran city was 2.11 percent. It is suspected that a good 
proportion of highly educated people have migrated to other countries because of political situation.

It is not possible to obtain the correct levels of fertility and mortality of the population of Kabul city, as the simplest statistical data required for such an estimation are not available. For proper development planning for the provision of health and educational facilities, employment, primary necessities of the citizens, provision and expansion of the drinking water and electricity systems, provision of the residence, the expansion and effective arrangement of the communication and transportational means, to mention only a few, information on population growth and thus on the three major components of growth, namely, fertility, mortality and migration becomes absolutely essential. Using Rele's method, the Crude Birth Rate (CBR) of the city nearey was estimated to be $\sqrt{42}$ and Total Fertility Rate (TFR) 6 . These figures show that fertility level is not only higher than the urban fertility of many other developing countries; but it is also higher than the rural fertility of some developing countries. District-wise differential shows that third district with a TFR of about 5 has the lowest fertility level in the city. It should be noted that this district had high female literacy rate and the higher female economic activity rate. The negative relationship between these factors and fertility are well docuriented. The highest fertility rate of the ninth district could be due to low literacy level and low participation rate coupled with the highest proportion of working population in agriculture and related activities - more than 18 percent of the workers in agriculture and related work were residing in this district.

As stated earlier, data on mortality of Kabul city is not available. The results of some socio-economic and health surveys done 
in the city revealed a crude death rate of about 20 and infant mortality rate of 101 - showing a higher level of mortality.

Of the 1986 population of the city, 40 percent were migrants which is considerably higher than the corresponding figure (29\%) of the 1965 situation. Two-fifths of the total migrants had come from Parwan and Kabul Provinces and with Wardak, Logar, Ghazni and Laghman two-thirds of the total migrants. Most of the migrants were short distance migrants. Atleast one migrant was found in 69 percent of the total households. Of the one person households, more than four-flfths were migrant households.

The excess of adolescent and young adults, generally observed anong migrants of the cities in other developing countries is not found among the migrants of Kabul city. The possible reason for this may be the military law and war situation mentioned earlier.

A comparison of the male and female migrants shows that male migrants on an average were older than female migrants - the median age being 27.54 years and 25.89 years respectively. It was found that the proportion of female migrants in 15-39 age group was about 48 percent; while for males this proportion was only 36 percent - again showing abnormal situation. But after age 40 the proportion of males was much nore than that of females, as military law is not applicable to those aged 40 years or above.

The age distribution of migrants by duration of residence showed the expected tendency, that the average age of migrants bearing a positive relation to duration of residence.

Both migrants and non-migrants of the 1986 population had abnormal sex ratio by age. Both of them had more or less the same patter: - the sex ratio for migrants and non-migrants increase upto age 15 then decrease in the age group $15-39$ and again increase at the higher ages. 
This is a peculiar situation observed in Kabul city, the reason for which has already been given while discussing general sex ratio.

About 55 percent of the total migrants of Kabul city in 1986 were illiterate; whereas the corresponding figure for non-migrants was only 35 percent. The migrant-non-migrant differential was found to be very high, particularly among females. It may be the outcome of the higher differential of the female educational facilities between Kabul city and the rest of the country, supplemented by cultural feelings which are comparatively more favourable to female education in Kabul city.

The general economic activity rate for 1986 population of Kabul city worked out to be 65 percent for males and 8 percent for females. In Kabul city the crude activity rate has registered a decline over the 21 year periods between 1965 and 1986, mainly due to a decline in male activity rate. However, the female activity rate has shown $\mathrm{an}$ increase. This increase may be due to the out-migration of adult males and consequent need for some women to earn extra money and/ or the preference shown by some employers for female workers as they are comparatively cheap.

The general activity rate was very much the same as that of 1976 Tehran city where the rate was 65 percent for males and 10 percent for females.

The wide male-female differential in work participation is comnon for all districts. This difference was found to be maximum for the first district and minimum for the third district. Female work participation rate was highest in third district where some industries preferred to employ women to save on labour cost. Moreover, the third district had the highest literacy rate and the lowest level of fertility 
among all districts which enable them to enter labour force. The maximum female activity rate $(19 \%)$ was found to be in the 25-29 age groups which is exactly the same for the females of Tehran city. For males, the rates indicate a central plateau pattern for age groups 3049 of Kabul city and 30-44 of Tehran city were almost all the persons were economically active. The participation in economic activity by female children is low in Kabul and Tehran while that of older women were almost negligible for Kabul city and a noticeable enough proportion of them in Tehran city were working. A comparison of the male age-specific activity rates of Kabul city with that of Tehran city shows that in Kabul ci ty participation rates were much higher both before age 25 and after age 50 .

The examination of marital status specific female activity rates by age shows the lowest level for currently married women as their financial protection is guaranteed by their husbands. Among females the highest level of participation was found for divorced women - reflecting the cultural situation, disapproval of divorce by society because of which self-supporting becomes indispensible for them. The maximum activity rates for currently married and never married women were found in 25-29 age group reaching 14.82 percent and 47.09 percent. The corresponding figures for widowed and divorced worked out to be 25.64 and 61.90 percent respectively in 35-39 age group.

Activity rates were higher among educated persons. For females It was higher among those with higher secondary level of education and women with low level of education had generally the lowest activity rates. While the activity rates of male workers were higher in each level of education, the highest rate for them was found in secondary level education. 
The economic dependency ratio (EDR) was very high in Kabul city. This ratio which was 109.3 for males, 156.1 for females and $205 .+1$ for total population of Greater Kabul in 1965 increased respectively to 133.7, 175.7 and 309.4 in 1986, mainly because of the increase in the number of students and the out-migration of a part of the working population in the age group 15-39. The high economic dependency ratio of Kabul city can also be seen by comparing it with that of Tehran city which was 101.73 for males; 126.24 for females and 238.40 for total population. As one would expect the female dependency ratio was much higher than that of males in all districts. The majority of districts had a dependency ratio more than 312 , indicating a heavy burden on economically active population.

Gross years of active life of Kabul city male population was found to be 44 years constituting 80 percent of their working life span. For females the gross years of active life when worked out separately gives 4.3 years for 10-64 years and 4.1 years for 15-59 years of working Iife span.

On the average, the length of economically active years to be lived by male inhabitants of Kabul city in 1986 was 30.65 years. With $e_{0}^{0}=48.62$, they had 17.97 years of inactive life. The loss of active life by mortality was found to be 8 years.

The retirement rate was found to be fairly stable and low (less than 12 per 1000) until 1 age 60; but, thereafter the rates increased rapidly. Further, it was found that half of Kabul city economically active population retired after 65 years of age - median age of retirement being 65.31 years.

It was observed that 84 percent of the population entered the labour force when they were below 20 years of age and nearly 40 per- 
of Tehran city - 74.41 percent. The male-female literacy differential, unlike the total population, in economically active population is in favour of fernales, both in Kabul and in Tehran, indicating that in both cities females with some level of education were interested in work participation and had comparatively better opportunity to enter into labour force. The proportion of illiterate workers was much higher for males compared to females in all industries. Educated workers were predominantly secondary school graduates in Kabul city and primary school graduates in Tehran city. This shows that in Kabul city the highest proportion of working population was better educated than that of Tehran city. The post-graduates have a share of only 1.31 and 1.35 percent for males and females respectively which is low compared to the corresponding figures for Tehran city -2.5 percent for males and 2.68 percent for females. The out-migration of workers of this educational category, besides comparatively less higher educational facilities, may be one possible reason for this. More than 85 percent of the total literate workers were engaged in service sector.

More than half of the economically active female population were currently married and among them half were working in professional, technical and related activities. When clerical and related activities were also included, three-fourths of the married women workers were accounted for. Similar is the case for never married; but a large proportion of widowed were found in non-modern sector activities. Half of the divorced women were in the modern sector. That is, majority of these vomen must have been working while they obtained divorce as most of nodern sector occupations have age limitation in entry.

Eighty percent of economically active population were engaged in service sector which is almost double of the corresponding percentage of Tehran city. The high percentage of workers of Kabul city in service 
sector is suspected to be because of the inclusion of manufacturing activities and/or an increased share of informal sector activities.

Slightly over half of the total economically active population were production/related workers. Probably this higher share is mainly because of the increase in the number of transport workers, especially during 1979-86. The male-female differential in the distribution of workers into different industries was common for all industries, especially for transport and communication. But the differences were not much as shown by a low index of dissimilarity (8.92). Unlike industrial distribution there was wide variation in the occupational distribution between male and female workers as the index of dissimilarity was 56.26 .

Female workers were found to be concentrating in specific occupations. More women workers were in professional, technical and related activities and in that particularly in teaching. This is a common finding in many studies as shown in the respective chapter.

of the total migrants, nearly 66 percent were economically active and among them 6.39 percent were females. The share of migrant workers among total workers of Kabul city was $58.5,33.39$ and 55.82 percent for males, females and total respectively. The sex ratio of the migrant workers was 1465.83 males per 100 females. Among migrant workers illiteracy was found to be high among males. Those migrants whose place of last work was outside the country, a good proportion had higher level education and among those who came from Kabul Province, illiteracy was high. It shows that long distance migrants are mostly highly educated whereas it is not so for short distance migrants. Migrant-non-migrant differences were observed in occupation and it was more pronounced among females. While nearly four-fifths of female non-migrants were in modern 
sector activities, migrants were less than two-thirds in these occupational groups. An examination of the relative difference in occupational divisions for migrants and non-migrants in Kabul city reveals that for females a very high difference is observed in production/related workers and administrators and managers groups, high difference in the division of hotels and restaurants workers.

The available data in Kabul city suggest that under-utilisation of labour is not considerable compared to that in cities of many other countries; but it will become a serious problem in the near future if the present rate of population growth continues.

Unemp loyment rate in Kabul city in 1986 was 3.17 percent: 3.15 percent for males and 3.30 percent for females. These rates are slightly lower than the corresponding rates in Tehran city. But for cities of less developed countries these rates are quite low. The age-specific unemployment rates show that the rate of unemployment was quite high among the young adults. This is also supported by the percentage distribution of unemployed persons by age. In general, females had higher rate of unemployment than males.

Of the total number of unemployed persons 88.82 persons were males. A heavy concentration of unemployed females was found in 10-24 age group. Twenty percent of unemployed males was below 15 years of age. The majority of unemployed males were seasonally unemployed. Among females a large proportion was seeking job for the first time. The situation was found to be different in Tehran city where slightly more than four-fifths of the unemployed persons for total as well as for males and females separately fall in the category of "seeking job for the first time.

The female unemployment rate by age and marital status shows that the highest rate is for divorced women followed by never married group. But for divorced women unemployment rate at age 40 and above is zei 
Of the total unemployed women of Kabul city in 1986, nearly three-fifths were never married and one-third were currently married. Among the never married unemployed women, 89 percent were below the age of 25 years. Nearly 45 percent of currently married unemployed females were in the age group 20-29. More unemployed widows were 60 years and above.

The unemployment rate was minimum in the second district and maximum in ninth district. The male-female differential in unemployment rate is common for all the districts. Among them this gap is highest for the sixth district where more than 8 percent of the female labour force was unemployed. Eleventh district had the highest share in total unemployed persons of Kabul city and the second district the lowest. It is expected as the former is the most populated and the latter is least populated district.

An examination of the occupation of educated persons revealed some under-utilization of ski11. That is, many were working in occupations requiring lesser educational attainment than that they have.

\subsection{CONCLUSIONS AND RECOMENDATIONS}

In general, it can be said that the analysis of the available data on economically active population in Kabul city revealed a typical pattern expected of a city in less developed countries. There was a fairly high level of work participation for adult males, low female work participation, high economic dependency ratio, low median age of entry, very high median age of retirement, low literacy rate of labour force and noticeable share of migrants in the total labour force. A comparison with the city of Tehran has shown several similarities between the two cities. From the levels and patterns of economically active population analysed here one is tempted to conclude that Kabul 
city in 1986 is closer to Tehran in 1976 and if at all a shade behind in some aspects.

The study also revealed two important aspects regarding female labour force participation. First is the cultural supremacy in deciding female work participation in this city. This is reflected in their overal1 low work participation and the high rate of participation among divorcees. The second aspect is the role of education in over-riding effect of the first aspect mentioned above. This was revealed by the fact that more and more educated females were entering the labour force and a good proportion of the working women were educated. Thus, it seeris appropriate to mention in this context that an expansion of educational facilities, particularly for women, will go a long way in increasing the iemale labour force participation. This, incidentally, is a major factor that has been recommended by many to reduce fertility which should also be a major concern of the city. The available data in the city itself point towards this; that is, for example, the third district in Kabul city had the highest level of female labour force participation, highest female literacy rate, low female unemployment rate and compared to many other districts low economic dependency ratio and it also had the lower rate of fertility. By inference one can say that the low fertility level could be the result of high level of literacy and high female labour force participation. But, to establish this fact in Kabul city one needs more detailed demographic data.

The high proportion of labour in the service sector has been explained in terms of an increase in informal sector activities. That is, pressure from the supply side of labour market. But this is an intuitive conjecture. Detailed data along with the type of work, type of establishment affiliated to and income earned will throw some light in 
this matter. Considering the increasing importance that is belng given to informal sector in urban areas of less developed countries, this matter needs urgent attention.

Some other data gaps that need to be mentioned here regarding employment are: many avallable information were aggregated which conceal Important differences between male and female, migrants and non-migrants, educated and uneducated or the 11ke. Hence, disaggregated data will be of Immense use in understanding economically active population. As an analytical tool the working life table has shed some light on the dynamic aspects of current labour force in Kabul city. It has highlighted the information required for manpower planning whioh should be concerned with the increasing number of persons entering labour market. The rates of accession, retirement and loss due to death are needed to assess the long term employment opportunities for the unemployed persons in the labour force. It is admitted that they are crude rates. This is because of the use of questionable data as input which can be avoided if reliable information can be obtained and made available to the researcher. For example, data on mortality of the city population, leave alone workers, are not available.

Another area of concern is the compulsory enlistment for military service resulting in the out-migration of prime age males, robbing the city of their fruitful services and disturbing family life. Also of concern is the out-migration of highly educated people due to the unfavourable polftical atmosphere.

Under-utilization of labour force also could not be properly studied because of paucity of data. For proper study of underemployment one would need data of occupation cross classified by hours of work and education which, it is suggested, future censuses should take into account. 
The low unemployment rate in the city, it is suspected, is an underestimation. It is possible that unemployment may be more in the form of underemployment. May be it is a question of inappropriate jobs than lack of jobs. Thus defined it becomes a problem of development calling for more and more appropriate and adequate jobs to absorb both the unemployed and under-employed persons.

In sumg it appears that the government has shown its concern by collecting and publishing data on economically active population; but more is to be done in the same direction to help planning for proper utilization of the labour force. The absence of an explicit and comprehensive labour policy is felt throughout. 


\section{REFERENCES}

Alonzo R.P., Trends in Poverty and Labour Market outcomes in the Metro Manila Area in Rodgers G., Urban Poverty and the Labour Market, Access to Jobs and Incomes in Asia and Latin American Cities, International Labour office, Geneva-1989.

Arturo R. et, al., Poverty and Labour Market Access in Guatemala city, in Rodgers G., Urban Poverty and the Labour Market, Access to Jobs and Incomes in Asian and Latin American Cities, International Labour office, Geneva, 1989.

Camazon D. et, al., Labهur Market Performance and Urban Poverty in Panama, in Rodgers G., Urban Poverty and the Labour Market, Access to Jobs and Incomes in Asian and Lat In American Cities, International Labour office, Geneva,1989.

Central statistics office, Afghanistan, Statistical Year Book 1366 (March 1987 - March 1988), Kabul, 1988.

- Afghanistan, Statistical Year Book of 1365 (March 1986 March 1987), Kabul, 1987.

- Afghanistan, Soclo-Economic and Health Survey of Households in Qala1 Ahmad Khan, Kabul, 1984.

- Afghanistan, Full Results of the First Afghan population Census 1979, Kabul, 1983.

Afghanistan, Final Results of the 1986 Population Census of Kabul City, Kabul, 1988.

Afghanistan, Statistical Year Book of 1367 (March 1988 March 1989), Kabul, 1989.

- Afghanistan, The Results of a Sample Survey of Income and Expenditure of the Households of Kabul City 1366 (March 1987 March 1988), Central Statistics Office, Kabul, 1988.

- Afghanistan, stat1st1cal Year Book 1367 (March 1988 - March 1989), Central Statistics Office, Kabul, 1989.

Durand J.D., The Labour Force in Economic Development, Princeton University Press, New Jersey - 1975.

Evers H.D., Urban poverty and Labour Supply strategles in Jakarta, in Rodgers G. Urban Poverty and the Labour Market, Access to Jobs and Incomes in Asian and Latin American Cities, International Labour office, Geneva - 1989.

Fan S.C., Population of Hong Kong, 1961, 1971, Demography India, Vol.IV No.2, December 1975. 
Gamrah H.A., Fertility and Childhood Mortality by Mother's and Father's Education in Cairo, 1976. Population Bulletin of the UN ECWA, No.19, December 1980 .

Good M.Jo.D. et,al., Social status and Fertility, A study of a Town and three Villages in North-Western Iran, Population Studies, Vol. 34, No.2(B), July, 1980 .

Government of Afghanistan, Population of Greater Kabul,1965, statistical Department, Ministry of Planning, Kabul,1968.

Government of India, Family Welfare Programme in India Year Book 1987-88, Government of India Ministry of Health and Family Welfare, Department of Family Welfare, New Delhi,1989.

Hawley A.H., Human Ecology: A Theory of Community Structure, The Ronald Press Company, New York, 1950. - et,al., The Expectation of Working Iife in Peninsular Malaysia, 1970, Department of Statistics, Kuala Lumpur, 1974.

Jatoba J., Urban Poverty Labour Markets and Regional differentiation in Brazil, in Rodgers G., Urban Poverty and The Labour Market, Access to Jobs and Incomes in Asian and Latin American Cities, International Labour office, Geneva, 1989.

Levitan S.A., et,al., Human Resources and Labour Market Harper and Row, Publishers, New York, 1972 .

Peek P., The Education and Employment of Children: A Comparative study of San Salvador and Khartoum, in standing G. and Sheehan G. Labour Force Participation in Low-income Countries, Internationál Labour office, Geneva, 1979 .

pollack M., Poverty and the Labour Market in Costa Rica, in Rodger G., Urban Poverty and the Labour Market, Access to Jobs and Incomes in Asian and Latin American Cities, International Labour office, Geneva, 1989 .

Pollack M. and Uthoff A., Poverty in the Labour Market: Greater Santiago, 1965-85, in Rodgers G., Urban Poverty and the Labour Market, Access to Jobs and Incomes in Asian and Latin American Cities, International Labour office, Geneva, 1989.

Rao V.L.S.P, and Tewari V.K., The Structure of an Indian Metropolis A study of Bangalore, Allied Publishers Private Limited, New Delhi, 1979.

Rele J.R., Fertility Analysis Through Extension of stable population Concepts, Institute of International studies, University of California, Berkeley, 1967. 
United Nations Fund for Population Activities, Afghanistan, Report of Mission on Needs Assessment for Population Assistance, United Nations Fund for Population Activities, New York, 1987.

- National Census and statistics office, Working Life Tables for males and females in the Philippines: 1970, Monograph No.7, UNFPA-NCSO Research Project, National Economic and Development Authority, National Census and statistics office, Manila, 1977.

United Nations, Migration, Population Growth and Employment in Metropolitan Areas of Selected Developing Countries, New York, 1985 .

- Trends in Population Policy, Department of International Economic and Social Affairs, Population Studies No.114, United Nations, New York, 1989.

- World Population Policies, Vol.1, Department of International Economic and Social Affairs, Population studies, No.102, United Nations, New York, 1987.

- Manual III, Methods for Population Projection by Sex and Age, New York, 1956.

- The Determinants and Consequences of Population Trends, Vol.I, New York, 1973 .

United Nations Fund for Population Activities, National Consus and statistics office, Population Research Project, Differentials in Socio-economic and Demographic Characteristics of Non-migrants and Migrants to and from Manila and Rizal, Gaining Provinces and Losing Provinces, Philippines:1960-70, Monograph No.12, National Census and statistics office, Manila, 1978.

World Bank, World Development Report 1988, Oxford University Press, New York, 1988.

Zachariah K.C., Migrants in Greater Bombay, Asia Publishing House, Bombay, 1968 . 


\section{APPENDIX 1}

Selected information of Settled Population of Afghanistan

\begin{tabular}{|c|c|c|c|c|}
\hline \multirow[b]{2}{*}{ Characteristics } & \multicolumn{4}{|c|}{ Year } \\
\hline & $1972-73$ & 1979 & $1980-85$ & 2020-2025 \\
\hline (1) & (2) & $(3)$ & (4) & $(5)$ \\
\hline Population (in million) & 10.020 & 13.051 & 16.519 & 37.917 \\
\hline Population $0-14 \quad(\%)$ & 45.49 & 45.39 & 41.8 & 29.0 \\
\hline Population $60+$ & 5.51 & 6.55 & 4.6 & 7.4 \\
\hline Life expectancy : Total & 35 & 40.7 & NA & NA \\
\hline Ma le & 34 & NA & NA & NA \\
\hline Female & 36 & NA & NA & $\mathrm{NA}$ \\
\hline $\begin{array}{r}\text { Urban life expectancy : } \\
\text { Male }\end{array}$ & NA & $48.62^{*}$ & NA & NA \\
\hline Female & NA & $49.90 *$ & NA & NA \\
\hline Crude Death Rate & 30 & 28.67 & $27 \cdot 30$ & 11.6 \\
\hline $\begin{array}{r}\text { Infant Mortality Rate : } \\
\text { Tota } 1\end{array}$ & NA & 182 & 193.8 & 111.6 \\
\hline Urban & NA & 129.93 & NA & NA \\
\hline Rura 1 & NA & 188.99 & NA & NA \\
\hline Crude Birth Rate & 48.52 & 47.85 & 48.9 & 22.4 \\
\hline Total Fertility Rate & 7.7 & 7.1 & 6.9 & 2.7 \\
\hline Contraceptive Prevalence Rate & 2.0 & NA & NA & NA \\
\hline $\begin{array}{l}\text { Feirale Mean Age at First } \\
\text { Marriage }\end{array}$ & NA & 17.8 & NA & NA \\
\hline Net Migration & NA & NA & -16.0 & 0.0 \\
\hline Population Urban (\%) & NA & 15.43 & 18.5 & 48.6 \\
\hline Population growth rate: Total & NA & 2.60 & 1.92 & - \\
\hline Urban & NA & 2.18 & 3.9 & 2.8 \\
\hline Ever-married 15t: Males & 66.0 & 67.13 & NA & NA \\
\hline Females & 90.0 & 90.47 & NA & NA \\
\hline $\begin{array}{l}\text { Currently married in } 15-19 \\
\text { age group }(\%): \text { Males }\end{array}$ & 8 & 9.4 & NA & NA \\
\hline Females & 50 & 53.1 & NA & NA \\
\hline $\begin{array}{r}\text { Work Participation Rate: Males } \\
\text { Females }\end{array}$ & $\begin{array}{r}67 \\
8\end{array}$ & $\begin{array}{r}73.0 \\
6.2\end{array}$ & $\begin{array}{l}\text { NA } \\
\text { NA }\end{array}$ & NA \\
\hline
\end{tabular}


APPENDIX 1 continued. .

\begin{tabular}{llrrrr}
\hline & $(1)$ & $(2)$ & $(3)$ & $(4)$ & $(5)$ \\
\hline \multirow{2}{*}{ Effective Literacy Rate : } & 11 & 22.3 & NA & NA \\
& Males & 18.7 & 35.2 & NA & NA \\
& Females & 2.8 & 8.3 & NA & NA \\
\hline
\end{tabular}

Sources: 1. For 1972-73 : James F. Spitler and Nancy B. Frank., Afghanistan : A Demographic Uncertainty. International Research Document No.6, U.S. Department of Commerce, Bureau of Census, 1977.

2. For 1979 : Central Statistical Office, Afghanistan, Full Results of the First Afghan Population Census 1979, Kabul, 1983.

3. For 1980-85 and 2020-2025 : United Nations, World Population Policies, Vol.I, United Nations, New York, 1987.

* Esmatullah Rumzl, Mortality Levels and Differential in Urban Afghanistan 1978-79," Seminar Paper, IIPS, 1985.

Note. NA - Not available. 


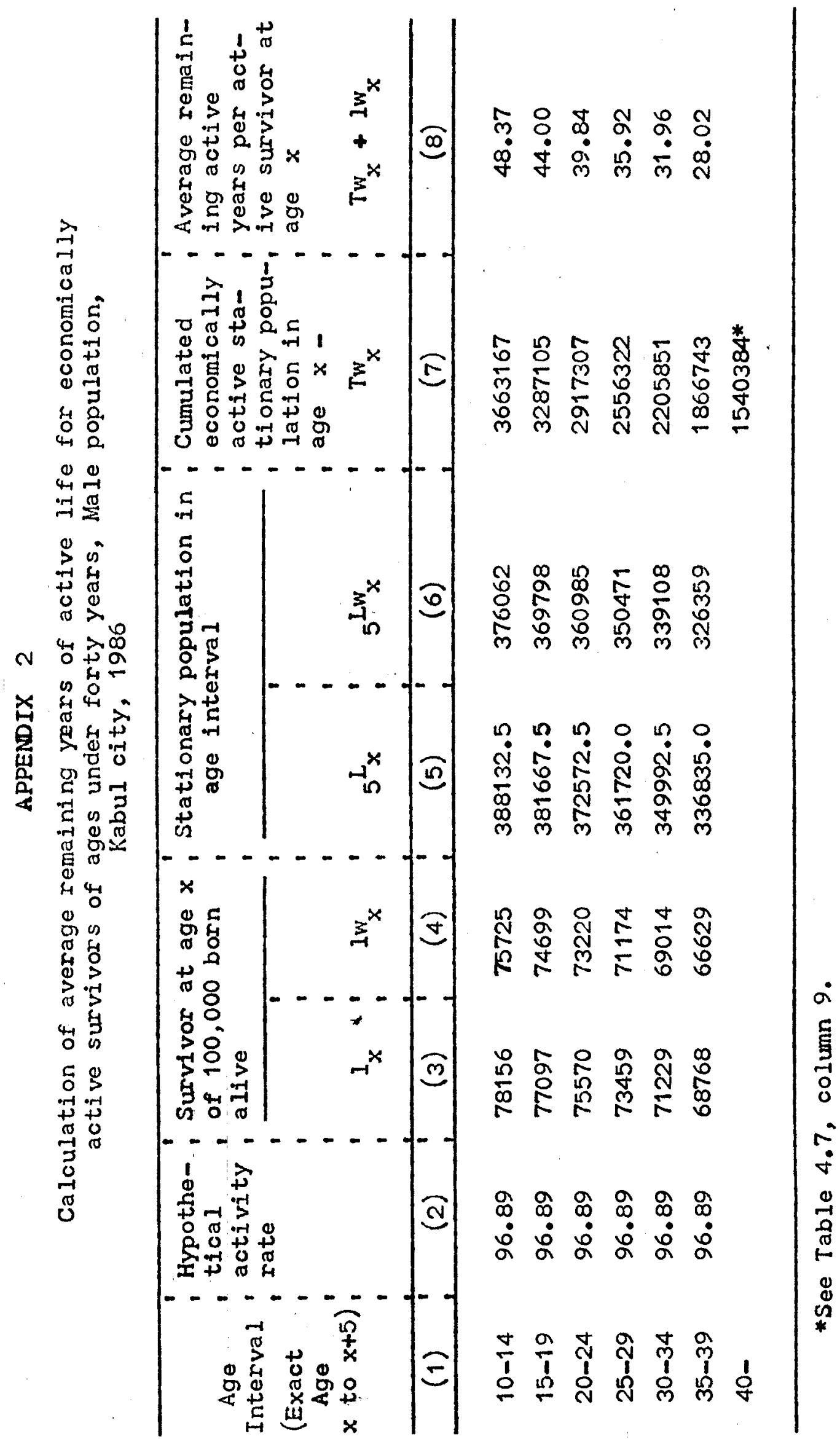




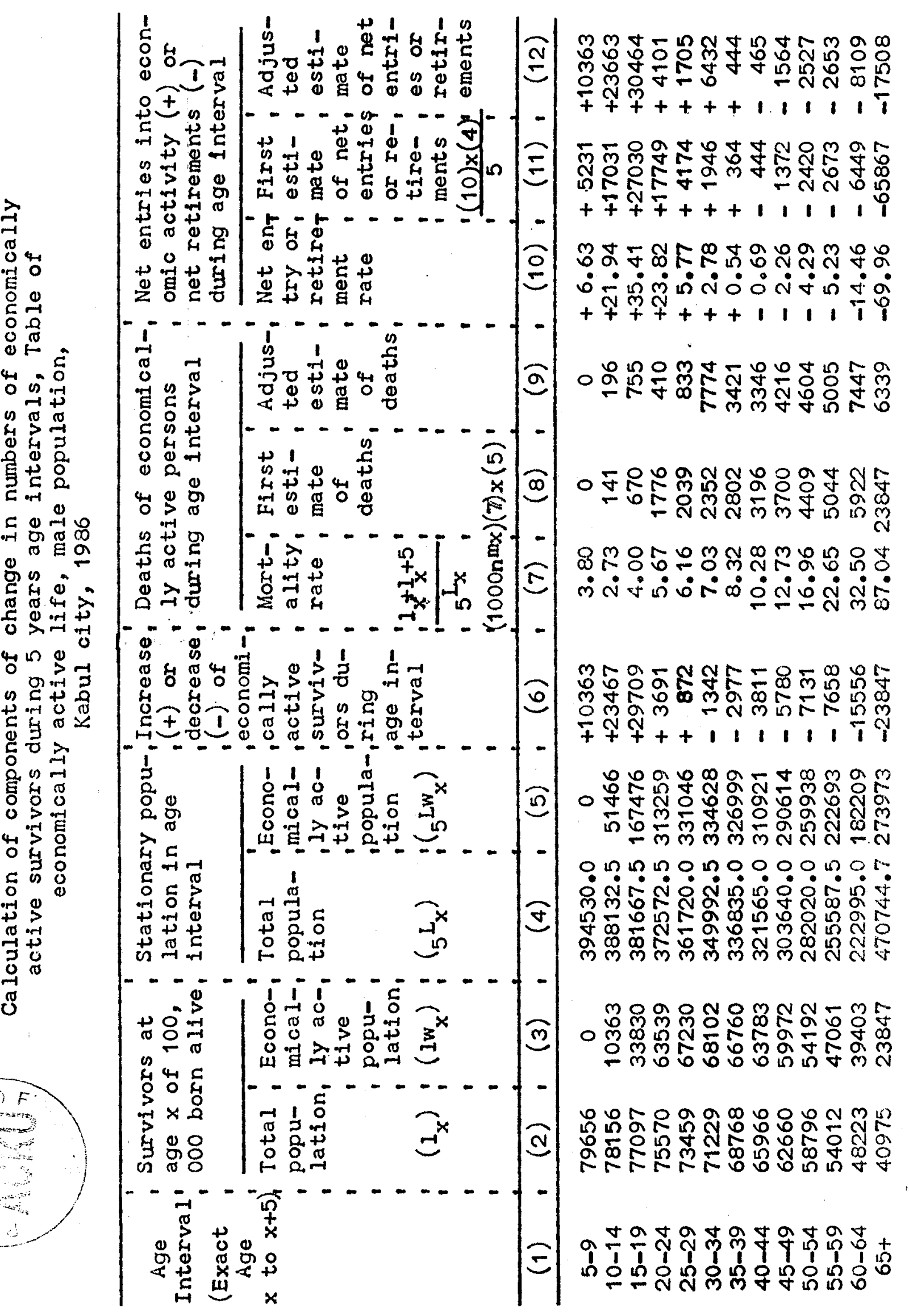




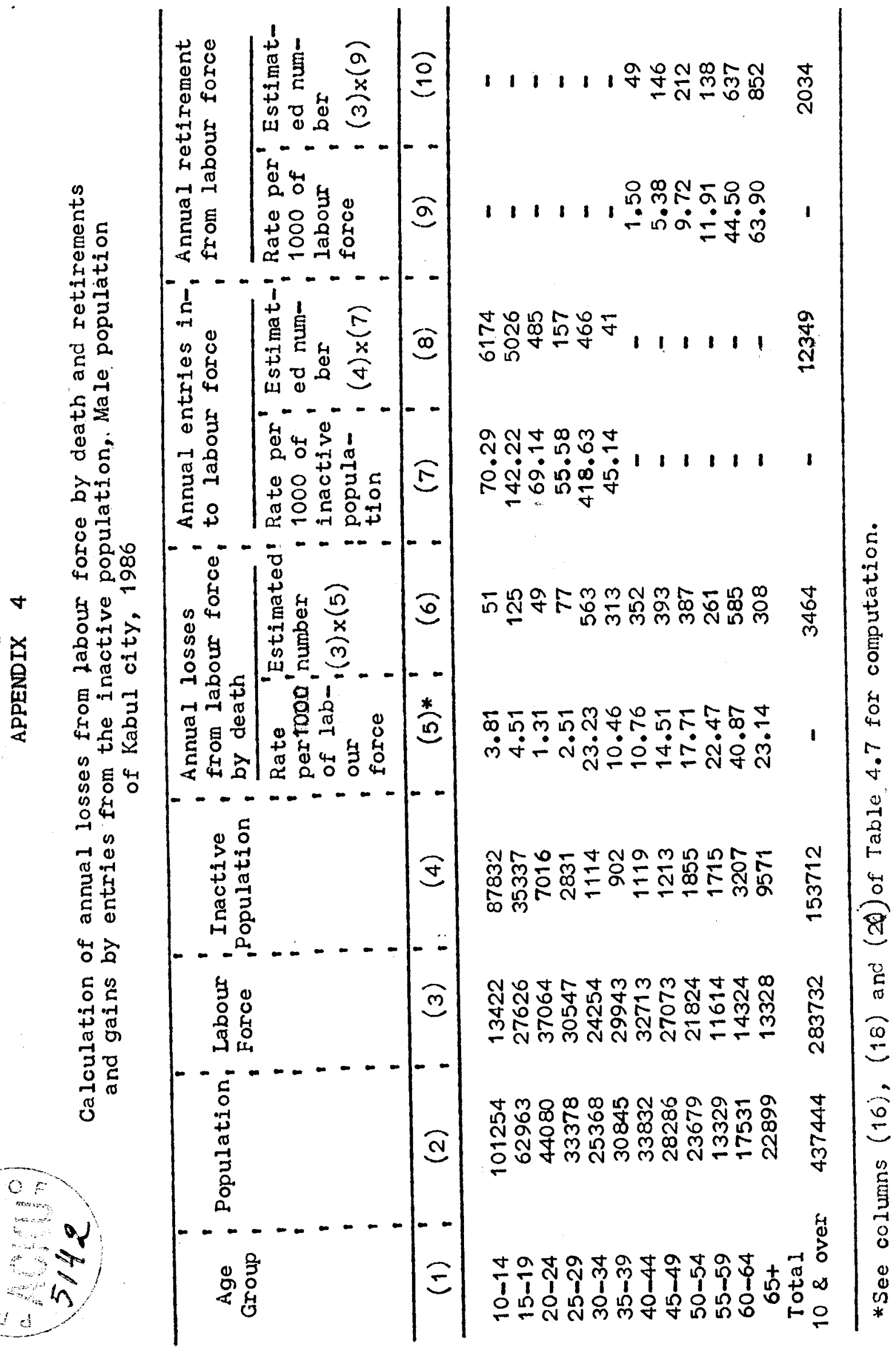

